\title{
QUALIDADE MICROBIOLÓGICA DA ÁGUA DE CULTIVO E DE MEXILHÕES Perna perna (Linnaeus, 1758) COMERCIALIZADOS EM UBATUBA, SP
}

\author{
Juliana Antunes GaLVÃo
}

Dissertação apresentada à Escola Superior de Agricultura “Luiz de Queiroz”, Universidade de São Paulo, para obtenção do título de Mestre em Ciências, Área de Concentração: Ciência e Tecnologia de Alimentos.

\author{
P I R A C I C A B A \\ Estado de São Paulo - Brasil
}

Maio - 2004 


\title{
QUALIDADE MICROBIOLÓGICA DA ÁGUA DE CULTIVO E DE MEXILHÕES Perna perna (Linnaeus, 1758) COMERCIALIZADOS EM UBATUBA, SP
}

\author{
Juliana Antunes Galvão \\ Licenciatura em Ciências Biológicas
}

Orientador: Profa. Dra. MARÍLIA OETTERER

\begin{abstract}
Dissertação apresentada à Escola Superior de Agricultura “Luiz de Queiroz”, Universidade de São Paulo, para obtenção do título de Mestre em Ciências, Área de Concentração: Ciência e Tecnologia de Alimentos.
\end{abstract}

P I R A C I C A B A

Estado de São Paulo - Brasil

Maio - 2004 


\section{Dados Internacionais de Catalogação na Publicação (CIP)}

DIVISÃO DE BIBLIOTECA E DOCUMENTAÇÃO - ESALQ/USP

\section{Galvão, Juliana Antunes}

Qualidade microbiológica da água de cultivo e de mexilhões Perna perna

(Linnaeus, 1758) comercializados em Ubatuba, SP / Juliana Antunes Galvão.

- Piracicaba, 2004.

109 p. : il.

Dissertação (mestrado) - - Escola Superior de Agricultura Luiz de Queiroz, 2004.

Bibliografia.

1. Meio ambiente aquático 2. Mexilhão 3. Microbiologia da água - Qualidade Mitilicultura 5. Molusco bivalve I. Título

CDD 639.4

"Permitida a cópia total ou parcial deste documento, desde que citada a fonte - O autor" 


\section{Ao meu Deus que me sustentou em todos os momentos}

A minha mãe Raquel, por sempre colocar os filhos como prioridade em sua vida; pelo amor, por ser meu porto seguro e por estar comigo em toda e qualquer circunstância.

Ao meu pai Lauro por sempre estar torcendo por mim, vibrando com cada conquista.

A minha irmãzinha Ana Cláudia pela preocupação, atenção e amor.

A minha avó Lourdes pelo amor incondicional, e por tantas renúncias que fez à favor dos filhos e netos.

Ao meu avô Rubens pela evidente satisfação em ter uma neta estudando na ESALQ.

A meu tios, primos e demais familiares pelo carinho e apoio.

A meus familiares que infelizmente partiram antes do término desse trabalho, na certeza que iremos ainda nos encontrar.

DEDICO

À Lílian, Lúcia e Michelle por serem minhas irmãs do coração, 


\section{HOMENAGEM}

\section{À $\operatorname{Prof}^{\mathrm{a}} \operatorname{Dr}^{\mathrm{a}}$ Marília Oetterer}

Por ser responsável pelo meu ingresso no mestrado;

Por acreditar na minha capacidade e possibilitar meu crescimento pessoal e profissional;

Por ter me dado oportunidade de elaborar e trabalhar num projeto financiado pela FAPESP;

Por sempre valorizar e elogiar meu trabalho, independente das falhas;

Pela experiente orientação que permitiu meu amadurecimento;

Pelo exemplo de vida, profissionalismo e amor à pesquisa;

Pela amizade, carinho e apoio em todos os momentos; 


\section{AGRADECIMENTOS}

- À Escola Superior de Agricultura "Luiz de Queiroz" e ao Programa de Pós Graduação em Ciência e Tecnologia de Alimentos pela formação profissional;

- Ao Departamento de Agroindústria, Alimentos e Nutrição pela abertura e por toda a estrutura e assistência necessárias à realização desse trabalho;

- À Fundação de Amparo à Pesquisa do Estado de São Paulo pelo financiamento do projeto;

- Ao Prof Dr. Ernani Porto pela amizade, atenção, e participação efetiva no andamento dessa pesquisa;

- À Prof ${ }^{\mathrm{a}}$ Dr $^{\mathrm{a}}$ Marta Spoto e Carmem Castilho pela amizade e sugestões no decorrer deste trabalho;

- Ao Prof. Dr. Luiz Henrique Beirão da Universidade Federal de Santa Catarina pela atenção e apoio;

- Ao Prof Dr. Nilson Augusto Villa Nova pelas sugestões quanto aos dados de índice pluviométrico e pelo fornecimento de preciosos contatos;

- Aos demais professores da ESALQ pelos ensinamentos adquiridos e exemplo profissional;

- À médica veterinária Ana Maria Cruz pela grande amizade, profissionalismo e valiosas sugestões;

- À pesquisadora do Instituto de Pesca Valéria Gelli pela amizade e auxílios técnicos prestados;

- Às instituições parceiras deste projeto: ESALQ, MAPA, APTA - IPESCA e Prefeitura Municipal de Ubatuba na pessoa do Eng. Agrônomo Antônio Marchiori;

- À Associação dos Maricultores do Estado de São Paulo - AMESP pela colaboração no decorrer deste trabalho; 
- Ao Laboratório Regional de Apoio Animal - LARA, sediado em Campinas, SP, na pessoa do Dr. José Guedes Deák, pela parceria essencial na execução das análises laboratoriais. À chefe da seção de físico-química Amélia Mitico Nishikawa Barbosa e ao chefe da seção de Microbiologia Amaury dos Santos e demais funcionários pela realização das análises microbiológicas e físicoquímicas;

- À Cláudia Megumi Miyaki, Fiscal Federal Agropecuário pela amizade e auxílios técnicos prestados durante toda a execução deste trabalho;

- Ao Fiscal Federal Agropecuário Nelson Antonio Ferreira pela amizade, simpatia e por estar sempre pronto à ajudar;

- À Denise Regina Silva Abreu do Instituto Agronômico de Campinas - IAC pelos dados cedidos de insolação diária e índice pluviométrico da região de Ubatuba, SP;

- À bióloga da CETESB Cláudia Lamparelli pelo profissionalismo e contatos cedidos;

- À SABESP pelas informações cedidas na pessoa do químico Antonio Dirceu Pigatto Azevedo;

- À bióloga Roberta Rizzo por caminhar comigo desde a época da graduação iniciação científica, posteriormente transformando-se em companheira de trabalho e colega do curso de mestrado, por todos os momentos compartilhados, pelo amor e pela amizade;

- À Ivani Moreno pela amizade e pela experiência compartilhada de anos de trabalho em laboratório;

- Ao Rubens Pereira, pelas formatações das figuras;

- À Regina Lourenço, secretária do Programa de Pós-Graduação em Ciências e Tecnologia de Alimentos pela amizade e estímulo;

- A todos os funcionários e amigos do Departamento de Agroindústria, Alimentos e Nutrição;

- As bibliotecárias Beatriz, Ligiana e Eliana pela amizade e serviços prestados; 
- À Midiam Gustinelli, pela amizade de todas as horas, e pela competência profissional;

- À Vilma e Sílvio do Serviço de Comutação Bibliográfica da Biblioteca Central pelo profissionalismo, dedicação e amizade;

- À zootecnista Érika Fabiana Furlan pelo companheirismo e cumplicidade em todas as horas, pela calma e paz que sempre transmite, pela competência profissional, e pela grande e sólida amizade que este projeto possibilitou-nos construir;

- Aos alunos da equipe do Projeto de Políticas Públicas: Eduardo Salán, Viviane Angeli, Paula Porreli, Fernando Rinaldi, Vitor Pontinha e Marcelo Fischer pela amizade, alegria e pelo primoroso trabalho em equipe;

- Às Repúblicas Zona Rural, Vira Latas, Arado, Deus quis, Caminho do Céu, Batkverna e Uspeão, pela amizade e inúmeras integrações;

- Aos colegas do Programa de Pós-Graduação em Ciência e Tecnologia, Débora, Lia, Ricardo, Aelson, Marielen, Fabiana, Eloíse, Selma, Ana Cecília e Renata;

- Aos amigos do Programa de Pós-Graduação em Produção Animal, por todos os inesquecíveis momentos compartilhados;

- Aos professores, funcionários, amigos e alunos do SESI CE - $\mathbf{1 6 4}$ pelo carinho, compreensão e apoio;

- Às famílias Xavier da Costa - PA e Pittol Firme - ES pelo amor e carinho;

- Ao Paulo Henrique Aguiar pelo apoio no período das disciplinas;

- Ao Luciano Mincarelli Monfrin pelo carinho, cumplicidade e por estar sempre disposto a ajudar;

- A meus amigos que mesmo distantes, se fizeram presentes em todos os momentos; 


\section{SUMÁRIO}

Página

LISTA DE FIGURAS............................................................................... xii

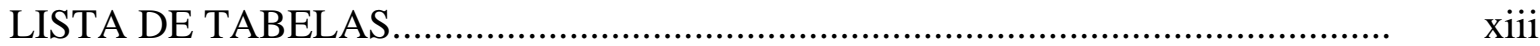

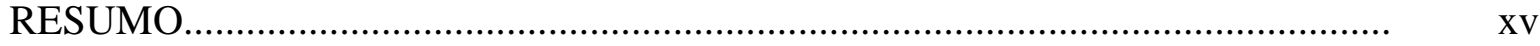

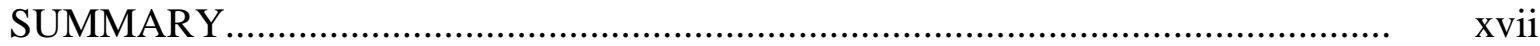

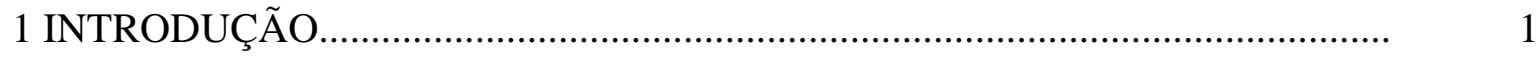

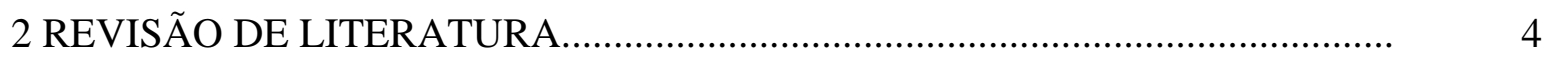

2.1 Os bivalves e o ambiente aquático................................................................ 4

2.2 Características biológicas dos bivalves.........................................................

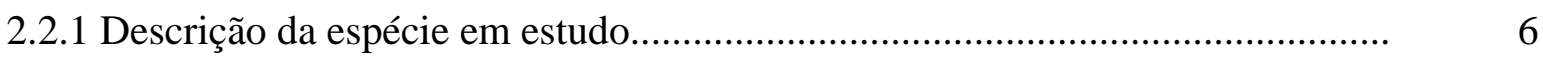

2.3 Microrganismos indicadores de importância na análise de água........................ 7

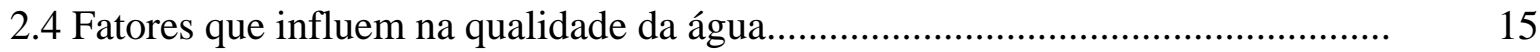

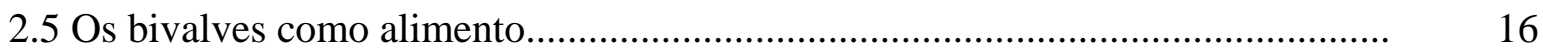

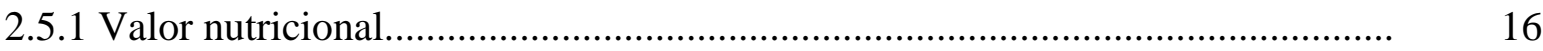

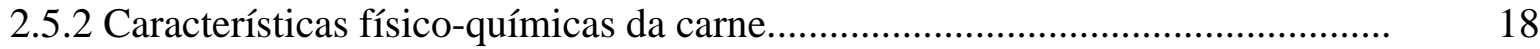

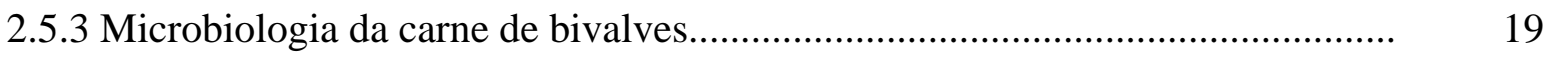

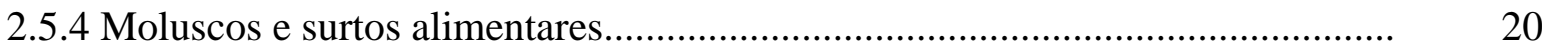

2.6 Considerações sobre o desenvolvimento pesqueiro brasileiro e do litoral norte

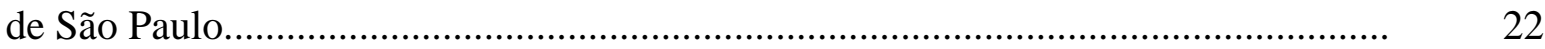

2.6.1 A aqüicultura no município de Ubatuba, SP............................................. 24

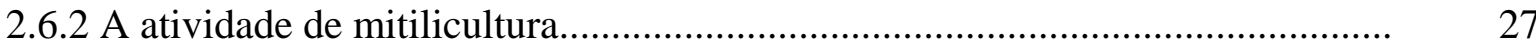


2.6.3 Diagnósticos de mercado e consumo................................................................. 30

3 MATERIAL E MÉTODOS............................................................................ 32

3.1 Eleição e caracterização dos pontos de coleta....................................................... 32

3.2 Metodologia de coleta da água...........................................................................

3.3 Metodologia de coleta dos mexilhões............................................................... 36

3.4 Análises físico-químicas............................................................................... 38

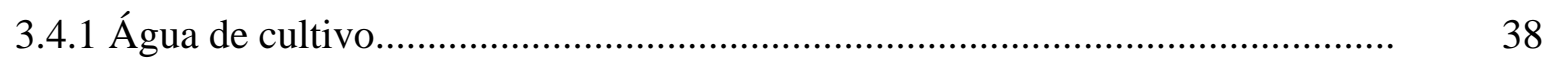

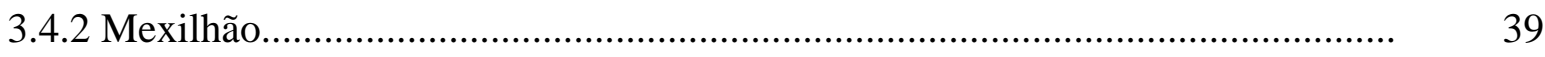

3.5 Análises microbiológicas.................................................................................. 40

3.5.1 Preparo das amostras de água........................................................................... 40

3.5.2 Microrganismos analisados nas amostras de água............................................... 40

3.5.2.1 Coliformes totais e fecais...........................................................................

3.5.2.2 Enterococcus sp.................................................................................... 41

3.5.2.3 Clostrídios sulfito-redutores......................................................................

3.5.2.4 Pesquisa de Salmonella.sp......................................................................... 42

3.5.2.5 Sthaphylococcus aureus............................................................................

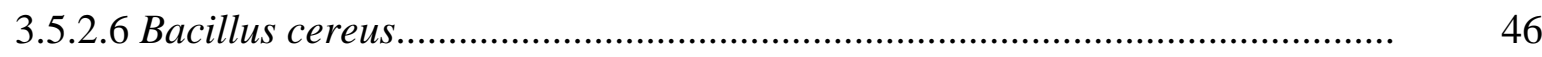

3.5.2.7 Microrganismos aeróbicos mesófilos (heterotróficos)...................................... 47

3.5.2.8 Contagem de bolores e leveduras.................................................................. 48

3.5.3 Preparo das amostras de mexilhões.................................................................... 48

3.5.4 Microrganismos analisados nas amostras de mexilhão......................................... 49

3.5.4.1 Coliformes totais e fecais...........................................................................

3.5.4.2 Enterococcus sp.................................................................................

3.5.4.3 Clostrídios Sulfito Redutores.................................................................... 50

3.5.4.4 Clostridium perfringens.............................................................................. 50

3.5.4.5 Pesquisa de Salmonella sp......................................................................

3.5.4.6 Staphylococcus aureus............................................................................

3.5.4.7 Bacillus cereus......................................................................................... 
3.5.4.8 Microrganismos aeróbios mesófilos (Heterotróficos)...................................... 52

3.5.4.9 Contagem de bolores e leveduras................................................................ 52

3.6 Análise estatística..............................................................................................

4 RESULTADOS E DISCUSSÃO......................................................................

4.1 Água de cultivo........................................................................................

4.1.2 Análises físico-químicas................................................................................ 53

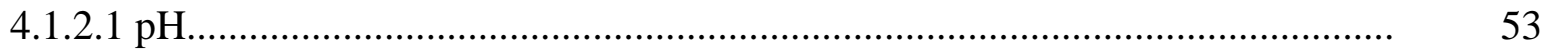

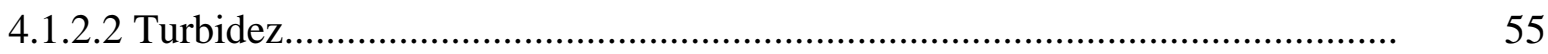

4.1.2.3 Temperatura ambiente e da água................................................................ 56

4.1.3 Análises microbiológicas............................................................................... 59

4.1.3.1 Coliformes totais e fecais.......................................................................... 59

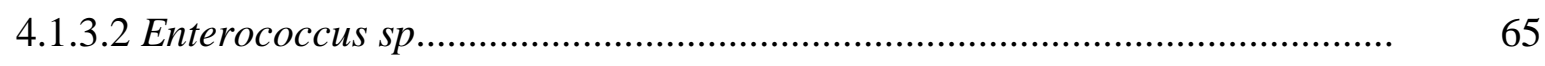

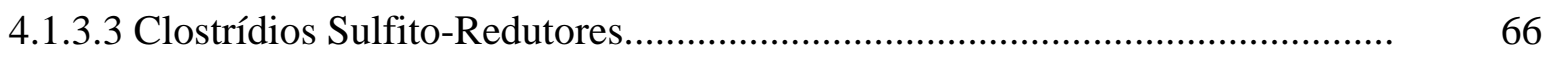

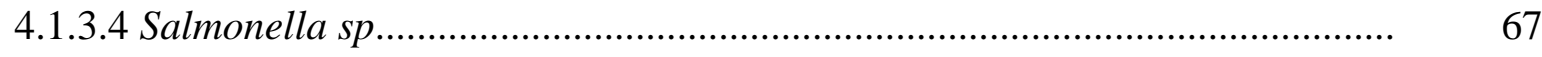

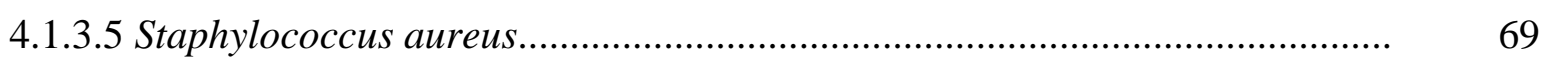

4.1.3.6 Bacillus cereus......................................................................................

4.1.3.7 Microrganismos aeróbios mesófilos (Heterotróficos)........................................ 71

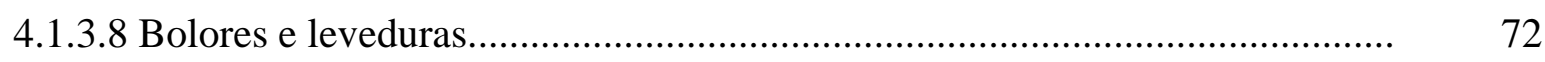

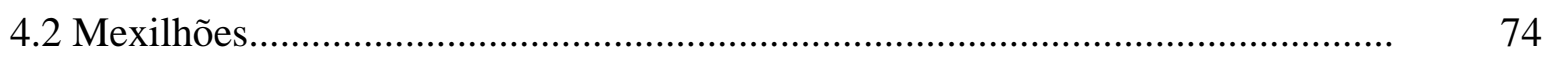

4.2.1 Análises físico-químicas..................................................................................

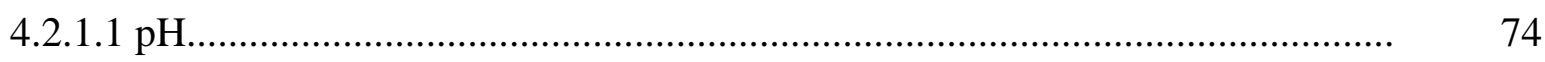

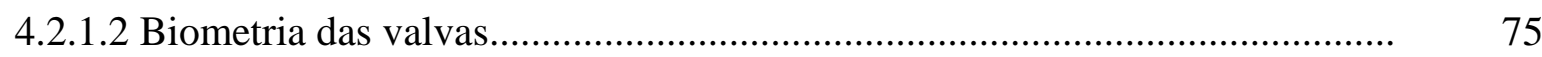

4.2.2 Análises microbiológicas.................................................................................

4.2.2.1 Coliformes totais e fecais..........................................................................

4.2.2.2 Clostrídios Sulfito Redutores e Clostridium perfringens.................................. 81

4.2.2.3 Enterococcus sp..................................................................................... 82

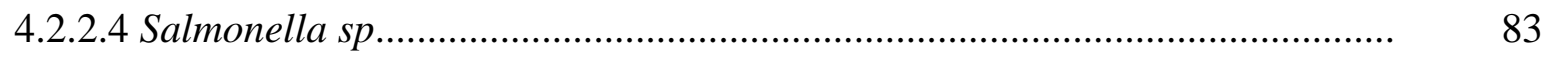

4.2.2.5 Staphylococcus aureus.............................................................................. $\quad 85$

4.2.2.6 Bacillus cereus........................................................................................

4.2.2.7 Microrganismos aeróbios mesófilos (Heterotróficos)........................................ 88 


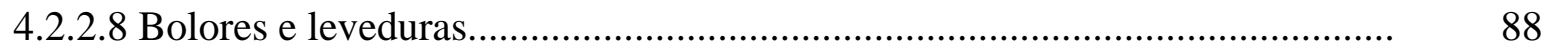

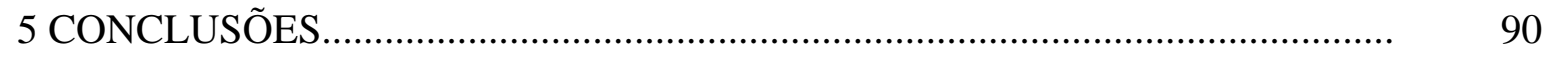

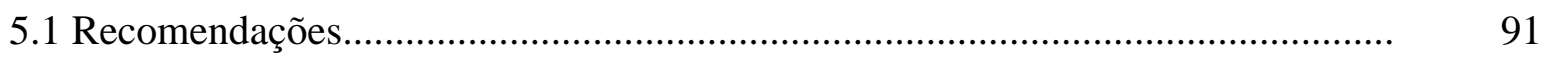

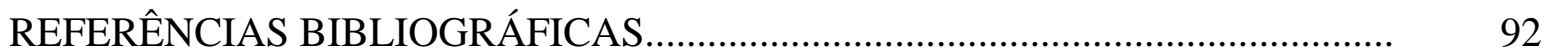




\section{LISTA DE FIGURAS}

Página

1 Mapa referente aos pontos de coleta de Ubatuba, SP..................................... 33

2 Barco cedido pelos maricultores para as coletas das amostras............................ 34

3 Coleta da água superficial dos pontos de cultivo eleitos................................... 35

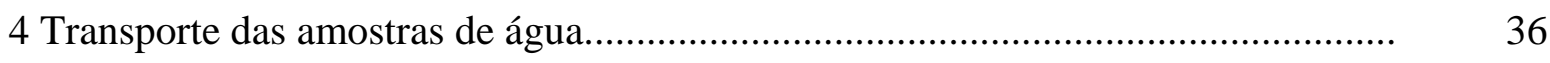

5 Coleta dos mexilhões das cordas de cultivo "Long line”.................................. 37

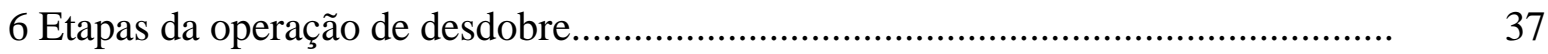

7 Lavagem com água do mar ou água tratada (dependendo do ponto de cultivo) e

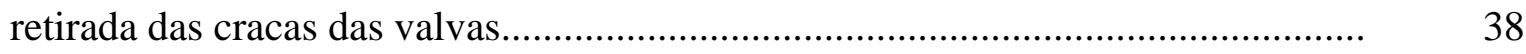

8 Mexilhões sendo transportados em sacos de ráfia............................................ 38

9 Medição das valvas dos mexilhões...............................................................

10 Abertura das valvas e retirada da carne........................................................... 49 


\section{LISTA DE TABELAS}

Página

$1 \mathrm{pH}$ em amostras de água do mar, referente ao fator praias................................. 54

$2 \mathrm{pH}$ em amostras de água do mar, segundo os meses de coleta............................ 54

3 Turbidez da água dos pontos de cultivo nos referidos meses de coleta (UNT)...... 56

4 Temperatura ambiente $\left({ }^{0} \mathrm{C}\right)$ registrada nos pontos de coleta................................ 57

5 Temperatura da água de cultivo $\left({ }^{0} \mathrm{C}\right)$ nos pontos de coleta.................................. 58

6 Coliformes totais em NMP/100mL na água de cultivo (médias de triplicatas)....... 60

7 Coliformes fecais em NMP/100mL na água de cultivo (médias de triplicatas)..... $\quad 60$

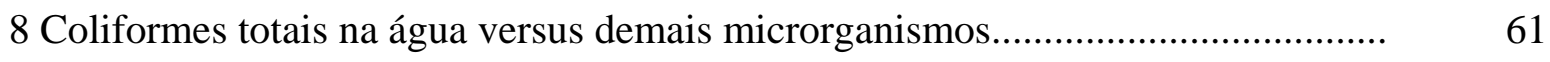

9 Microrganismos analisados na água versus índice pluviométrico......................... 62

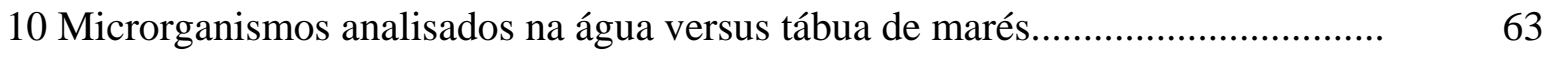

11 Microrganismos analisados na água versus insolação diárias (h)....................... 63

12 Enterococcus sp em NMP/100 mL na água de cultivo (médias de triplicatas)..... 65

13 Clostrídios Sulfito Redutores em NMP/100 mL na água de cultivo (médias de

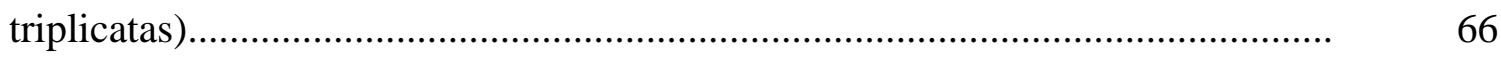

14 Salmonella sp em 25 mL na água de cultivo (médias de triplicatas)................... 67

15 Staphylococcus aureus UFC/ mL na água de cultivo (médias de triplicatas)....... $\quad 70$

16 Bacillus cereus UFC/mL na água de cultivo (médias de triplicatas).................. 70

17 Heterotróficos UFC/mL na água de cultivo (médias de triplicatas).................... 71

18 Bolores e Leveduras UFC/mL na água de cultivo (médias de triplicatas)............ 73

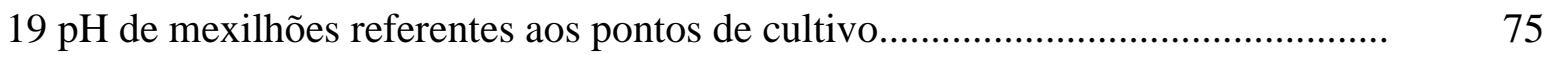

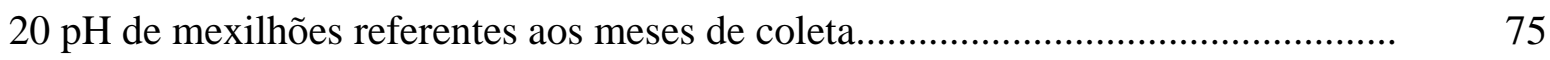

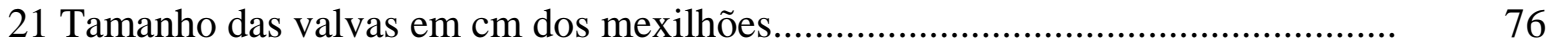


22 Coliformes totais NMP/g em mexilhões coletados nos diferentes pontos de cultivo (médias de duplicatas) ...................................................................

23 Coliformes fecais NMP/g em mexilhões coletados nos diferentes pontos de

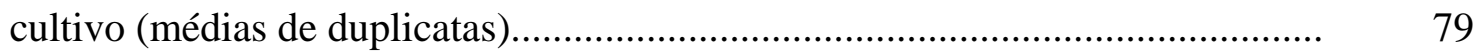

24 Coliformes totais e fecais da água versus do mexilhão................................... 80

25 Clostrídios Sulfito Redutores NMP/g em mexilhões coletados nos diferentes

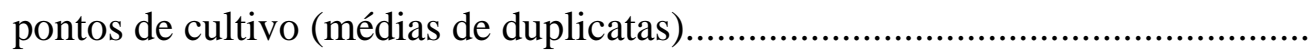

26 Clostridium perfringens NMP/g em mexilhões coletados nos diferentes pontos de cultivo (médias de duplicatas) .......................................................................

27 Enterococcus sp NMP/g em mexilhões coletados nos diferentes pontos de cultivo (médias de duplicatas).

28 Salmonella em 25/g em mexilhões coletados nos diferentes pontos de cultivo (médias de duplicatas)

29 Sthapylococcus aureus UFC/g em mexilhões coletados nos diferentes pontos de cultivo (médias de duplicatas).

30 Bacillus cereus UFC/g em mexilhões coletados nos diferentes pontos de cultivo (médias de duplicatas).

31 Heterotróficos UFC/g em mexilhões coletados nos diferentes pontos de cultivo (médias de duplicatas).

32 Bolores e Leveduras UFC/g em mexilhões coletados nos diferentes pontos de cultivo (médias de duplicatas). 


\title{
QUALIDADE MICROBIOLÓGICA DA ÁGUA DE CULTIVO E DE MEXILHÕES Perna perna (Linnaeus, 1758) COMERCIALIZADOS EM UBATUBA - SP
}

\author{
Autora: JULIANA ANTUNES GALVAO \\ Orientador: Prof ${ }^{\mathrm{a}}$. Dr ${ }^{\mathrm{a}}$. MARÍLIA OETTERER
}

\section{RESUMO}

O consumo de moluscos bivalves pode representar sérios riscos à saúde pública, pois refletem diretamente as condições do meio ambiente. Desta forma considera-se de extrema importância o consumo de mexilhões livres de contaminação. Esta pesquisa objetivou estudar a qualidade microbiológica das águas e mexilhões de três pontos de cultivo do município de Ubatuba, SP, a saber: Engenho da Almada, Barra Seca e Costão do Cedro em um período compreendido entre novembro de 2002 e março de 2003, totalizando 5 coletas mensais. Analisou-se na água: Bacillus cereus, Clostrídios Sulfito Redutores, Aeróbios Mesófilos, Staphylococcus aureus, Coliformes totais e fecais, Enterococos e Salmonella. Nos mexilhões foram analisados os mesmos microrganismos citados para água mais o Clostridium perfringens. Os resultados encontrados tanto para as análises de água como dos mexilhões foram satisfatórios, condizentes com a legislação brasileira em vigor, salvo a coleta do mês de março, do cultivo da Barra Seca, onde a média dos valores encontrados para coliformes fecais na água $\left(5,7 \times 10^{1} \mathrm{NMP} / 100 \mathrm{~mL}\right)$ foi superior ao recomendado pela legislação sendo 
detectado também neste mesmo cultivo e mês, presença de Salmonella em 25 g nas amostras de mexilhões. Mesmo que as contagens de $S$. aureus e B. cereus na carne estejam de acordo com a legislação em vigor, cuidados devem ser tomados quanto ao armazenamento e a forma de consumo. Averiguou-se a intensidade de interferências sazonais na contagem microbiana na água e constatou-se que a tábua de marés e o índice de insolação diária tiveram uma correlação negativa baixa, ao contrário do índice pluviométrico que apresentou correlação positiva alta. 


\title{
MICROBIOLOGY QUALITY OF THE CULTIVATION WATER AND MUSSELS Perna perna (Linnaeus, 1758) MARKETED IN UBATUBA, SP
}

\author{
Author: JULIANA ANTUNES GALVÃO \\ Adviser: Prof ${ }^{\mathrm{a}}$. Dr ${ }^{\mathrm{a}}$. MARÍLIA OETTERER
}

\section{SUMMARY}

The consumption of bivalve mollusks can represent serious risks to the public health, because they reflect the conditions of the environment directly. This way it is considered of extreme importance the consumption of mussels without contamination. This work aims of studing the water and mussels microbiology quality from three different seafood farms in Ubatuba, SP, to know: Engenho da Almada, Barra Seca and Costão do Cedro from November 2002 to March 2003, totaling five monthly. It was analyzed in the water: Bacillus cereus, Total Clostridia, Aerobic Mesophilic, Staphylococcus aureus, total and fecal coliforms, Enterococci and Salmonella. In the mussels the same microorganisms were analyzed mentioned for water more Clostridium perfringens. The results found in the water and in the mussels were satisfactory, suitable with the Brazilian legislation, except for the sample at Barra Seca's beach, in March. The average of the values found at that place for fecal coliformes in the water was higher $\left(5,7 \times 10^{1} \mathrm{MPN} / 100 \mathrm{~mL}\right)$ than the recommended by the legislation. Even in this collection, it was also detected Salmonella in $25 \mathrm{~g}$ of mussels. Even if the counts of $S$. aureus and $B$. cereus in the mussesls are in agreement with the legislation in vigor cares 
they should be taken with relationship to the storage and the consumption form. The intensity of seasonal interferences was discovered in the microbial count in the water, in which was verified that the board of tides and the index of daily heatstroke had a low negative correlation unlike the index pluviometric it presented high positive correlation 


\section{INTRODUÇÃO}

O crescimento da população mundial faz aumentar a necessidade de se produzir alimentos e buscar novas alternativas; o mar se afigura como uma das mais

promissoras dentre essas alternativas. É nesse sentido que a maricultura, constitui uma “nova fronteira” mundial na produção de alimentos. O mar deixa de ser tão somente uma fonte de turismo e lazer e passa a ser encarado como uma área cultivável que necessita de cuidados e proteção (Marques, 1998).

Um dos sistemas de produção alimentar que mais rapidamente se desenvolveu no mundo é a aqüicultura, chegando a atingir uma taxa de crescimento equivalente a 9,6\% ao ano na última década; este aumento está diretamente relacionado com a contribuição que o sistema oferece para diminuir a diferença entre a demanda e a oferta de produtos pesqueiros (Beirão et al., 2000).

A mitilicultura é uma das atividades mais produtivas da aqüicultura, sendo a mais próspera em diversas regiões do mundo, incluindo o Brasil, alcançando produtividade de até 30 t /ha/ano, o que representa a maior cifra obtida com modalidade de criação não sujeita a alimentação artificial. Além de diversos aspectos biológicos favoráveis, outros fatores como o baixo custo das instalações, facilidade de manejo e localização dos cultivos no mar contribuíram, em muito, para a expansão mundial dessa atividade nos últimos anos. O Brasil iniciou seus cultivos comerciais em 1989 com produção de 120 t e é atualmente, o principal produtor de mexilhões da América do Sul, tendo produzido 8.000 t em 1998 (Gelli et al., 1998; Moluscos..., 2002). No Brasil, a produção de bivalves está centrada nos estados do Rio de Janeiro, São Paulo e Santa Catarina, devido principalmente às características ambientais propícias ao 
desenvolvimento desses moluscos, os quais necessitam de águas de temperaturas amenas e ricas em nutrientes (Beirão et al., 2000).

No estado de São Paulo, estudos bioecológicos e de aprimoramento das técnicas de criação do mexilhão Perna perna iniciaram-se em 1976, sendo que a América Latina devido às suas condições geográficas tem grande potencial para produzir e exportar aos mercados dos Estados Unidos, Europa e Japão, os produtos da pesca e da aqüicultura.

A pesca tem sido, há milênios, uma atividade rotineira para as comunidades costeiras. Incerta e predatória, a extração dos recursos passou de uma atividade equilibrada e aceitável a uma dimensão drástica de sobre-exploração, provocada pelo crescente aumento populacional e conseqüente incremento no esforço de exploração, acompanhado pelo rápido aprimoramento das tecnologias de captura, por legislações impróprias, falta de fiscalização e desorganização do setor pesqueiro. Essa política vem ocasionando violentas quedas na biomassa, o que deriva em escassez dos recursos e quebra nos ciclos naturais, com conseqüentes impactos ecológicos, econômicos e sociais (Gelli \& Carneiro, 2003; Gelli et al.,1998).

A implantação da atividade de maricultura tem sido vista como meio de elevar a produtividade de áreas costeiras, promover o aumento de produção de alimentos e de desenvolvimento sócio-econômico de determinadas regiões, diminuir a pressão extrativa sobre os recursos explorados e de incorporar os pescadores a uma atividade planificada. No Brasil, estudos de custo e benefício da mitilicultura e outros tipos de criatórios mostraram viabilidade econômica, com investimentos e custo operacional relativamente baixos. A atividade poderá ajudar a conter o empobrecimento das comunidades artesanais que, com o declínio dos estoques pesqueiros, ficaram com poucas alternativas de renda para permanecer em suas terras (Gelli et al.,1998).

A tarefa de se estabelecer normas para a produção e consumo de moluscos não é simples, especialmente quando se considera que o país não tem tradição como produtor deste alimento e também que o consumo de moluscos pode representar sérios riscos à saúde pública, uma vez que os mesmos refletem diretamente as condições do 
meio ambiente. A segurança do consumidor de moluscos bivalves depende da sanidade destes, a qual por sua vez depende das condições físicas, químicas e microbiológicas do ambiente de origem, do manuseio e tecnologia pós-captura, bem como da existência de legislação adequada, que baseie a fiscalização em todas as etapas.

O objetivo desta pesquisa, foi diagnosticar a qualidade microbiológica da água de cultivo e dos mexilhões Perna perna comercializados na região de Ubatuba, subsídio fundamental para a estabilidade da produção, com conseqüente fixação do mitilicultor na atividade. Esta investigação é parte do projeto de Políticas Públicas designado de "Diagnóstico e intervenções emergentes para a comercialização de pescado - mexilhões no Litoral Norte, região de Ubatuba, SP”, o qual visa a implantação de uma unidade beneficiadora de produtos pesqueiros na região. 


\section{REVISÃO DE LITERATURA}

\subsection{Os bivalves e o ambiente aquático}

A água constitui um dos elementos essenciais à vida de todo ser humano; suas funções no abastecimento público, industrial e agropecuário na preservação da vida aquática, na recreação e no transporte, demonstram essa vital importância. Ela cobre aproximadamente $3 / 4$ da superfície do planeta, sendo que a maior parte, 97,4\% é salgada e se encontra nos oceanos; $1,8 \%$ está congelada nas regiões polares e apenas o restante, 0,8\% de água doce, está disponível para a população da Terra não se conhecendo bem ainda qual é a fração que se encontra contaminada. A água atua, por conseqüência de sua contaminação, como importante veículo de inúmeras doenças, seja em decorrência de excretos humanos ou de animais, seja pela presença de substâncias químicas nocivas à saúde humana. A avaliação microbiológica da água de rios, riachos, lagos, oceanos ou provenientes de toda fonte que, por ventura, possa vir a prejudicar o homem, precisa ser realizada periodicamente para que o homem tenha controle do seu meio ambiente (Cavalcante et al. 1998; Guilherme et al., 2000).

A contaminação que vem ocorrendo ao longo dos anos é causada pelo desenvolvimento industrial, pelo crescimento demográfico e pela ocupação do solo de 
forma intensa e acelerada, aumentando consideravelmente o risco de doenças de transmissão de origem hídrica. A relação da qualidade da água com as doenças vem sendo observada desde a mais remota antiguidade, porém só foi comprovada cientificamente em 1854 por John Snow, quando demonstrou que a epidemia de cólera em Londres ocorreu devido à veiculação hídrica (Guilherme et al., 2000).

\subsection{Características biológicas dos bivalves}

A classe Bivalvia também chamada Pelecypoda ou ainda Lamellibranchia é formada por moluscos conhecidos por bivalves tais como mexilhões, ostras, vieiras, abalones, berbigões e outros mariscos. Os bivalves do Brasil estão distribuídos em 44 famílias com 379 espécies (Beirão et al., 2000; Cadogan, 1992; Santos, 1982).

A principal característica da concha dos bivalves é sua constituição em duas valvas, unidas dorsomedianamente por um ligamento de conchiolina não calcificada e que, da mesma forma que a concha, é secretada pelo manto (Boffi, 1979).

Os moluscos bivalves alimentam-se de plâncton, microrganismos e matéria orgânica. Através das brânquias, filtram cerca de 19 a 50 L/h, com alguma ou nenhuma capacidade seletiva acumulando na massa visceral, lúmem do intestino e hepatopâncreas, todos os agentes biológicos e abióticos que se encontram na água onde vivem. Durante o processo fisiológico da alimentação, a água entra na cavidade palial através do sifão aspirante, passando pela brânquia da óstia e é expelida pelo sifão expirante que é mais estreito que o sifão aspirante. Ambos os sifões possuem um véu que pode regular o fluxo da corrente de água. As partículas de alimentos são presas pelo muco espalhado sobre as lamelas branquiais concentrando-se assim, nos tecidos dos moluscos (Beirão et al., 2000; Cook, 1991; Espínola \& Dias, 1980; Lira et al., 2000; Martins, 1983b). 


\subsubsection{Descrição da espécie em estudo}

Mexilhão é o termo utilizado na língua portuguesa para denominar as diversas espécies de moluscos bivalves da família Mytilidae, sendo os gêneros mais comuns o Perna, Mytilus e Mytella, sendo essas espécies conhecidas popularmente por marisco (Boffi, 1979).

O mexilhão P. perna é um molusco bivalve com a seguinte classificação sistemática:

\section{Filo mollusca}

Classe Bivalvia Linnaeus, 1758

Ordem Mytiloida Férursac, 1822

Família Mytilidae Rafinesque, 1815

Gênero Perna Retzius, 1788

Espécie Perna perna Linnaeus, 1758 (Epagri, 1994)

A espécie Perna perna (L., 1758), consta na décima edição do System Nature com o nome de Mya Perna. O gênero Perna sp, foi criado por Retzius em 1788, tendo sido revalidado por Soot-Ryen em 1955. Esse gênero é caracterizado pela borda resilial perfurada, pela posição anterior do músculo retrator do pé e pela ausência total do músculo adutor anterior (Boffi, 1979; Galvão-Bueno, 1977).

O bivalve Perna perna tem um tamanho médio de 5 a $8 \mathrm{~cm}$ de comprimento e $3 \mathrm{~cm}$ de espessura. É o maior dos mitilídeos brasileiros, podendo atingir até $14 \mathrm{~cm}$ de comprimento (Klappenbach, 1964). Sua concha apresenta faixa resilial perfurada, linhas de crescimento bem marcada, cicatriz do retrator médio aproximadamente circular, por vezes lobada, separada do retrator posterior o qual forma uma cicatriz bilobada com o adutor posterior, adutor anterior ausente e cicatriz do retrator anterior alongada (Boffi, 1979; Klappenbach, 1964).

Nos mexilhões, os sexos são separados mas não há dimorfismo sexual. No entanto, a coloração das gônadas masculinas é esbranquiçada ou creme e, as gônadas 
femininas têm uma tonalidade mais alaranjado-avermelhada. Pelo fato dessa espécie ser tropical e sub-tropical, ela elimina gametas durante todo o ano, porém, de um modo geral, os períodos de fixação das larvas ocorrem no inverno e no verão, com pequenas variações de um ano para o outro (Fernandes, 1981).

O Perna perna é uma espécie nativa da África e hoje tem uma ampla distribuição no mundo, estando presente do continente africano até o Marrocos, e na América do Sul, desde a Venezuela, Uruguai e ao longo da costa Atlântica; no Brasil é abundante entre o Rio Grande do Sul e o Espírito Santo (Boffi, 1979; Sidall, 1980; Souza, 2003). É provável que esta espécie tenha sido introduzida no Brasil, nos séculos XVI a XIX, durante o tráfico negreiro, quando muitas embarcações mantinham um intenso comércio com a África e traziam em seus cascos os mexilhões incrustados. A melhor evidência de sua introdução foi obtida com o estudo das espécies presentes nos sambaquis. Na maioria dos vestígios arqueológicos - datados de 8.000 a 2.000 anos A.C.- deixados pelos pescadores, caçadores e coletores de moluscos que viviam no litoral do Estado do Rio de Janeiro não foram encontradas conchas de P. perna. Deste modo, a existência de casos recentes do comportamento invasor da espécie, sua distribuição disjunta nas Américas, além da fragilidade de dados que atestem a sua presença na pré-história brasileira, reforçam a hipótese de que o mexilhão $P$. perna seja uma espécie exótica no Brasil (Souza, 2003).

\subsection{Microrganismos indicadores de importância na análise de água}

A principal dificuldade do monitoramento da qualidade da água de um determinado local, é o estabelecimento de indicadores adequados e a definição dos critérios a serem adotados para esta avaliação. Nesse sentido, procura-se relacionar a presença de indicadores de poluição fecal no ambiente aquático e o risco potencial de se contrair doenças infecciosas por meio de sua utilização para recreação. Esses critérios devem estar sempre associados ao bem estar, à segurança e à saúde da população (Companhia de Tecnologia de Saneamento Ambiental - Cetesb, 2003). 
Segundo Cabelli et al. (1983), os melhores indicadores da presença de patógenos entéricos em fontes de poluição fecal devem ter as seguintes propriedades: estar presente em águas contaminadas por material fecal em densidades mais elevadas que os patógenos, ser incapaz de crescer em ambientes aquáticos mas capazes de sobreviver por mais tempo que os microrganismos patogênicos; apresentar resistência igual ou maior que os patógenos aos processos de desinfecção, ser facilmente enumerados por técnicas precisas; ser aplicável a todos os tipos de águas recreacionais naturais (doce, salobra, salina), estar ausente em águas não poluídas e associadas exclusivamente a despejos de fezes animais e humanas e apresentar densidade diretamente correlacionada com o grau de contaminação fecal. Esse conjunto de características constitui uma definição teórica de um indicador, pois nenhum tipo de bactéria preenche totalmente esses requisitos. No entanto, essas características restringem os indicadores a alguns grupos de bactérias.

Segundo Geldreich (1967), uma vez descoberto o fato de que as bactérias patogênicas transmitidas através da água contaminada eram responsáveis por uma série de infecções intestinais, foram desenvolvidos testes bacteriológicos capazes de indicar a contaminação fecal da água.

As condições do ambiente marinho dificultam o isolamento de bactérias patogênicas; fato que explica porque as pesquisas sobre a contaminação microbiana do litoral limitam-se geralmente à determinação das concentrações de bactérias indicadoras da poluição fecal (Plusquellec, 1983). Os coliformes e, mais recentemente, os estreptococos fecais são os microrganismos utilizados mundialmente para verificar a qualidade da água.

O conceito de utilizar coliformes para deduzir a presença de patógenos baseou-se num trabalho realizado em 1885 por Excherich, através da identificação do Bacilo de coli como fazendo parte da microflora intestinal natural de animais de sangue quente. Depois desse trabalho criaram-se correntes de pesquisadores que apoiam (Geldreich, 1967; Geldreich, 1970) e os que criticam (Dutka, 1973; Dutka \& Bell, 1973; Fair \& Morrison, 1967; Gallagher \& Spino, 1968; Hendricks \& Morrison, 1967; Kfir et al., 1992) o uso de coliformes para deduzir a presença, na água, de patógenos como 
Salmonella, Shigella, Vibrio e enterovírus. Sendo que alguns autores como Andrews et al. (1975) apoiam somente o uso de coliformes fecais e não os de coliformes totais para a água de cultivo, por julgar a segurança do molusco cultivado.

Estudos que buscaram relacionar indicadores de poluição com a presença de patógenos, demonstraram ser questionável a utilização, pelo National Shellfish Sanitation Program nos Estados Unidos, do NMP - Número Mais Provável de coliformes totais como critério para classificação das áreas de obtenção de bivalves (José, 1996).

A colimetria e classificação de águas provenientes de áreas onde são coletados ou cultivados bivalves constitui-se sempre em subsídio científico útil para as autoridades envolvidas na fiscalização e controle da qualidade dos alimentos, uma vez que a presença desses microrganismos indica as condições sanitárias desses produtos (Lira et al., 2000; National Advisory Committee on Microbiological Criteria for Foods, 1992).

Como indicador de poluição fecal recente, os coliformes termotolerantes apresentam-se em grandes densidades nas fezes, sendo portanto, facilmente isolados e identificados na água por meio de técnicas simples e rápidas, além de apresentarem sobrevivência praticamente semelhante à das bactérias enteropatogênicas. No entanto, a presença de coliformes termotolerantes nas águas não confere a estas uma condição infectante. Este sub-grupo das bactérias coliformes não é por si só prejudicial à saúde humana, apenas indica a possibilidade da presença de quaisquer organismos patogênicos (Cetesb, 2003).

Assim, alta densidade de coliformes termotolerantes em água marinha indica um elevado nível de contaminação por esgotos (Cetesb, 2003), o que poderá colocar em risco a saúde dos banhistas e a sanidade de bivalves provenientes dessa região, cujas conseqüências são imprevisíveis, dependendo basicamente, da saúde da população que gera esses esgotos, da taxa de filtração/fator de bioacumulação dos bivalves, e do grau de imunidade dos consumidores.

O grupo de coliformes totais inclui as bactérias na forma de bastonetes Gram negativos, não esporogênicos, aeróbias ou anaeróbias facultativas, capazes de 
fermentar a lactose com produção de gás, em 24 a 48 h, a $35^{\circ} \mathrm{C}$. O grupo inclui cerca de 20 espécies, dentre as quais encontram-se tanto bactérias originárias do trato gastrintestinal de humanos e outros animais de sangue quente, como também diversos gêneros e espécies de bactérias não entéricas, como Serratia e Aeromonas, por exemplo. Por essa razão, sua enumeração em água e alimentos é menos representativa como indicação de contaminação fecal, do que a enumeração de coliformes ou Escherichia coli (Franco \& Landgraf, 1996; Silva et al., 2000).

Para coliformes fecais ou coliformes termotolerantes a definição é a mesma de coliformes totais porém, restringindo-se aos microrganismos capazes de fermentar a lactose, com produção de gás em 24 h, e temperatura entre $44,5-45,5^{\circ} \mathrm{C}$. Esta definição objetivou em princípio, selecionar apenas os coliformes originários do trato gastrintestinal. Atualmente, sabe-se, que o grupo dos coliformes fecais inclui pelo menos três gêneros, Escherichia, Enterobacter e Klebsiella, dos quais dois (Enterobacter e Klebsiella) incluem cepas de origem não fecal. Por esse motivo, a presença de coliformes fecais em água e alimentos é menos representativa, como indicação de contaminação fecal, do que a enumeração direta de E. coli porém, muito mais significativa do que a presença de coliformes totais, dada a alta incidência de E. coli dentro do grupo fecal (Silva et al., 2000).

Cerca de $95 \%$ dos coliformes existentes nas fezes humanas e de outros animais são E. coli e, dentre as bactérias de habitat reconhecidamente fecal, dentro do grupo dos coliformes fecais, a E. coli, embora também possa ser introduzida a partir de fontes não fecais, é o melhor indicador de contaminação fecal conhecido até o momento, pois satisfaz todas as exigências de um indicador ideal de poluição. Por esse motivo, as tendências atuais se direcionam no sentido da detecção específica de E. coli, com o desenvolvimento de diversos métodos que permitem a enumeração rápida dessa espécie diretamente (Silva et al. 2000).

As principais vantagens dos coliformes como indicadores são o fato de se encontrarem normalmente, no intestino humano e animais de sangue quente e serem eliminadas em grandes quantidades nas fezes. Além disso, em função da sua prevalência nos esgotos podem ser quantificados na água recém contaminada, através de métodos 
simples. Outros microrganismos patógenos não têm sido utilizados como indicadores de poluição, devido à pequena população presente nas águas poluídas e às dificuldades de serem manipulados em técnicas de laboratório. As principais limitações são o fato de estarem incluídas no grupo das espécies de origem não fecal, que podem se multiplicar nas águas poluídas, além dos métodos de detecção serem sujeitos a falsos resultados negativos, por interferência de Pseudomonas e falsos positivos, através de ação sinergística de outras bactérias (American Public Health Association - APHA, 1992; Pelczar et al., 1996; Silva et al., 2000).

A investigação da presença da Pseudomonas aeruginosa, patógeno secundário oportunista, foi instituída pela União Européia em 1995, visando um melhor controle microbiológico da água. A pesquisa dessa bactéria é recomendada em paralelo a outros microrganismos patógenos, além de coliformes totais e fecais e da contagem padrão de bactérias. As $P$. aeruginosa são bactérias aeróbias estritas, Gram negativas, na forma de bastonetes, que crescem de 37 a $42^{\circ} \mathrm{C}$, são muito resistentes sobrevivendo em substratos com pequenas quantidades de nutrientes e capazes de inibir as bactérias do grupo coliforme, que são as que representam na legislação brasileira, o parâmetro para reprovar ou liberar determinada água para utilização humana. No Brasil, este grupo de bactérias tem aparecido com relativa freqüência em exames bacteriológicos para água clorada, não clorada e água mineral natural (Cavalcante et al., 1998; Guilherme et al., 2000; Silva et al., 2000).

No Brasil, o Conselho Nacional do Meio Ambiente (CONAMA), órgão que estabelece a classificação e normaliza os parâmetros de qualidade da água, segundo o seu uso preponderante, determina que a água salobra ou salina destinada à criação extensiva ou intensiva de espécies destinadas à alimentação humana e que serão ingeridas cruas, apresentem o NMP de bactérias coliformes fecais inferior a 14/100mL, com não mais de 10\% das amostras excedendo 43 coliformes/100 mL (Brasil, 1986), concordando com os valores citados por Cook (1991) para áreas submetidas ao monitoramento sanitário visando a classificação como área aprovada para a extração de bivalves. 
A contagem padrão de bactérias aeróbias heterotróficas mesófilas é considerada a técnica que melhor estima a densidade de bactérias contaminantes em águas não potável. A importância da avaliação do grau de poluição deste tipo de água utilizando a contagem padrão de bactérias, está relacionada à determinação da fonte poluidora, além de reforçar os padrões de qualidade da água e de traçar a sobrevivência de microrganismos (APHA, 1992). Esta contagem objetiva estimar o número de bactérias heterotróficas na água, particularmente como uma ferramenta para acompanhar variações nas condições de processo, no caso de água mineral, ou a eficiência das diversas etapas de tratamento, no caso de água tratada, permitindo ainda verificar as condições higiênicas em diferentes pontos da rede de distribuição (Silva et al., 2000).

O grupo de estreptococos fecais engloba as espécies Streptococus e Enterococcus spp do grupo sorológico D de Lancefield, que ocorrem em grande quantidade nas fezes humanas e de outros animais e têm o trato intestinal como habitat natural. São bactérias láticas na forma de cocos ou cocobacilos, Gram positivos, imóveis, catalase negativos e anaeróbios facultativos, cujas principais características diferenciadas são a capacidade de hidrolisar a esculina e crescer a $45^{\circ} \mathrm{C}$. O grupo dos enterococos é um subgrupo dos estreptococos fecais e inclui as espécies reclassificadas para o novo gênero Enterococcus spp, capazes de crescer a $10^{\circ} \mathrm{C}$, pH 9,6 e na presença de 6,5\% de $\mathrm{NaCl}$. Os estreptococos fecais normalmente não ocorrem em águas e solos virgens ou não poluída, estando as raras ocorrências relacionadas diretamente a animais de vida selvagem ou à drenagem do solo por enxurradas. Podem persistir por longo tempo em águas de irrigação, com alto teor eletrolítico, porém não se multiplicam na água poluída, sendo sua presença uma indicação de contaminação fecal recente. Adicionalmente, a identificação da espécie pode dar uma indicação da origem da contaminação fecal (humana ou animal). Sua maior resistência aos diversos processos de tratamento de esgoto, em comparação com os coliformes fecais, permite uma correlação mais direta com a sobrevivência sanitária, pois seu habitat não é restrito ao trato intestinal, podendo também ocorrer na vegetação e em certos tipos de solo. As principais aplicações da contagem de estreptococos fecais e enterococos são a avaliação da qualidade de mananciais e corpos d’água, a avaliação da qualidade da água tratada e a 
avaliação e monitoramento das condições higiênicas de sistemas industriais (Silva et al., 2000).

Os Clostrídios sulfito redutores têm sido utilizados como indicadores de contaminação fecal em água, pois sua incidência no meio aquático está constantemente associada a dejetos humanos, sendo sua presença comum em fezes, esgoto em água poluída. São esporogênicos e os esporos apresentam excepcional longevidade em água, em função da grande resistência aos desinfetantes e outras condições desfavoráveis do meio ambiente. Por esse motivo são úteis na detecção de contaminação fecal remota, em situações nas quais outros indicadores, como E. coli já não se encontrariam presentes. $\mathrm{O}$ principal representante deste grupo é o C. perfringens, bactéria anaeróbia Gram positiva, esporogênica, sulfito redutora, com temperatura de crescimento na faixa de 20 a $50^{\circ} \mathrm{C}$ e ótima de $45^{\circ} \mathrm{C}$. Tem sido utilizado como indicador de contaminação fecal em água, pois sua incidência no meio aquático está constantemente associada a dejetos humanos, sendo comum sua presença em fezes, esgotos e água poluída. Como é esporogênico, os esporos apresentam excepcional longevidade em água, em função da grande resistência aos desinfetantes e outras condições desfavoráveis do meio ambiente. Por esse motivo o C. perfringens é útel na detecção de contaminação fecal remota, em situações nas quais outros indicadores, como E. coli já não se encontrariam presentes. A detecção de $C$. perfringens é recomendada como complemento aos outros testes bacteriológicos de avaliação da qualidade da água uma vez que em esgoto e água poluída sua população geralmente excede a de vírus entéricos e bactérias patogênicas. A ausência em água destinada ao consumo humano também pode ser considerada uma indicação segura da ausência desse contaminantes (Silva et al., 2000).

O C. perfringens pode ser isolado do solo. Devido à sua ampla distribuição, é muito difícil evitar a contaminação dos alimentos com estes organismos, que ainda podem formar esporos termoresistentes, portanto, o cozimento nem sempre torna o alimento seguro. O pescado e seus produtos raramente têm sido responsáveis por surtos de envenenamento por $C$. perfringens, mas menciona-se que estas bactérias se encontram normalmente em mariscos, e às vezes, tanto o pescado in natura como o cozido podem estar contaminados com essa bactéria (Hernandez, 1985). 
O C. perfringens como é um microrganismo anaeróbio e esporulado, apresenta riscos para produtos embalados a vácuo ou submetidos ao tratamento térmico, conseqüentemente, produtos in natura contaminados com esse microrganismo podem se constituir em risco se forem utilizados como matéria-prima para o processamento térmico (enlatamento), ou embalados a vácuo.

É atribuído a pássaros marinhos a disseminação da Salmonella e outros patógenos na água. A Salmonella tem sido relatada como contaminante em várias espécies de pescado, principalmente em crustáceos como o camarão há evidências de que certos sorotipos desse microrganismo façam parte da microflora natural de alguns crustáceos em países tropicais (Huss et al., 2000; Silva et al., 2000; WHO, 1999).

Segundo Martins (1983a), sob o ponto de vista sanitário, a pesquisa de Salmonella e vibrios em moluscos bivalves, constitui em aspecto importante de saúde pública, pois esse microrganismo tem sido freqüentemente relacionado com a veiculação de gastroenterites e toxinfecções em populações que os consomem crus ou cozidos precariamente.

Salmonella está associada a áreas intestinais de animais de sangue quente, mas alguns estudos detectaram Salmonella associada a intestinos de carpa e tilápias provenientes da piscicultura (Huss et al., 2000).

Várias espécies de Vibrios conhecidas por serem patogênicas para humanos, também têm sido isolados de bivalves. Há muito o que se estudar sobre a ecologia desses microrganismos; sabe-se que quanto ao seu desenvolvimento, o sal é requerido ou aumenta seu crescimento. Estas bactérias fazem parte da microflora natural de estuários e águas marinhas, sugerindo a natureza nativa destas espécies, podendo se acumular nos tecidos dos bivalves durante sua alimentação. Com a possível exceção do Vibrio cholerae, a presença desses vibrios não têm conecção com poluição (Cook, 1991; Colwell et al., 1984).

As leveduras são encontradas ao lado de uma grande variedade de formas microbianas no ambiente marinho e representam contingente importante do total da microbiota existente. Exercem relevante papel na ecologia, como nos processos de conversão da matéria orgânica e inorgânica; e exercem a função de nutrientes para os 
habitantes de oceanos e mares, além de estarem incluídas entre os possíveis indicadores microbiológicos de poluição, sendo as espécies mais encontradas nesse meio a Cândida, Cryptococcus, Deparyomices, Rhodotorula e Trichosporon. Há evidências de que a contagem de leveduras na água do mar é paralela ao número de coliformes, e que quanto maior a contaminação da água por resíduos de esgotos não tratados, maior o número de leveduras presentes (Paula, 1978).

Nas técnicas propostas na $14^{\mathrm{a}}$ edição do "Standard Methods for the Examination of Water and Wastewater” (APHA, 1975), discute-se a possibilidade da utilização de fungos como novos indicadores de poluição, pois a água altamente poluída apresenta grande número de fungos do solo, incluindo leveduras. Portanto, um aumento no número de fungos indicaria a presença de material orgânico em grandes concentrações.

Em se tratando de bivalves e outras espécies de pescado, dá-se ênfase à qualidade da água, pois a classificação desta é fundamental para garantir a sanidade químico-microbiológica do molusco, pois monitorando as águas, os órgãos competentes poderão definir qual o local recomendado para a colheita e cultivo de bivalves (National Advisory Commitee on Microbiological Criteria for Foods,1992).

\subsection{Fatores que influem na qualidade da água}

Segundo a Cetesb, (2003), diversos são os fatores que concorrem para a presença de esgoto na praia. Dentre eles, pode-se citar como mais relevantes, a existência de sistemas de coleta e disposição dos efluentes domésticos gerados nas proximidades, a existência de cursos d’água afluindo ao mar, o aumento da população durante os períodos de temporada, a fisiografia da praia, a ocorrência de chuvas e as condições de maré.

Em sua maioria, os municípios litorâneos paulistas são desprovidos de sistemas adequados para a coleta, tratamento e disposição final dos esgotos. Os sistemas de coleta de esgotos existentes não são suficientes para afastar os despejos, que 
terminam por ser lançados em galerias de águas pluviais, córregos ou praias, o que naturalmente prejudica a qualidade da água.

Com relação à fisiografia da praia, é importante ressaltar que enseadas, baías e lagunas apresentam condições de diluição bastante inferiores às observadas em regiões costeiras abertas. A menor taxa de renovação da água dessas regiões contribui para a concentração dos poluentes, limitando, assim, a capacidade de diluição do meio receptor, como é o caso de muitos cultivos de mexilhões da região de Ubatuba (Cetesb, 2003; Salati Filho, 2001).

As chuvas constituem-se em uma das principais causas da deterioração da qualidade da água de praias. Esgotos, lixos e outros detritos são carreados para as praias através de galerias, córregos e canais de drenagem na ocorrência de chuvas, produzindo, assim, um aumento considerável na densidade de bactérias nas águas litorâneas. Deve-se lembrar ainda, a prática disseminada na região litorânea de se ligar o sistema coletor de águas pluviais à rede de esgotos, assim como a interligação dos sistemas coletores de esgoto à rede de drenagem pluvial, que também são muito prejudiciais à qualidade sanitária da água das praias (Cetesb, 2003; Salati Filho, 2001).

\subsection{Os bivalves como alimento}

\subsubsection{Valor nutricional}

A utilização de moluscos bivalves como alimento data da época paleozóica, sendo a qualidade sanitária do ambiente aquático onde estes são capturados ou cultivados, responsável, diretamente, pelos problemas de saúde pública que podem gerar quando consumidos, principalmente se ingeridos in natura (Santos, 1982).

Provavelmente foi no século passado nos restaurantes parisienses, que os moluscos começaram a ser reintegrados como iguaria fina. Segundo Fernández-Armesto (2004), os moluscos providos de conchas são consideradas uma comida eficiente, no sentido de que já vêm envoltos em uma concha funcional, quando dispostos à mesa, 
sendo este prato considerado extremamente nutritivo e apresentando desperdício mínimo.

O cultivo de moluscos foi realizado, inicialmente, pelos japoneses (2000 a. c.) e romanos (100 a. c.) alcançando, nos dias atuais, elevado nível tecnológico e dispondo ao consumidor um alimento nutritivo e de grande demanda.

O mexilhão apresenta pronunciada variação sazonal na composição de sua carne, com maior rendimento na época de desova. O valor energético é de $80 \mathrm{Kcal} / 100 \mathrm{~g}$, próximo ao dos peixes magros como a merluza (76Kcal/100g), enquanto que as ostras possuem em média $44 \mathrm{Kcal} / 100 \mathrm{~g}$. Apresentam 1 a 7\% de glicogênio, teor elevado em relação às outras carnes e peixes, onde este carboidrato se encontra em baixa proporção. A fração protéica do pescado situa-se na faixa de 8,4\% a 17\%; para mariscos e ostras os valores médios são de 6\% e 13\%, respectivamente (Espínola \& Dias, 1980).

Furtado et al. (1998), analisaram sururu (Mytella falcata), e berbigão (Anomalocardia brasiliana). A espécie $M$. falcata apresentou teores médios de umidade de $30,65 \%$ e de proteína de 56,44\%, enquanto que, para a espécie A. brasiliana os teores foram 25,62\% e 48,14\%, respectivamente. O teor de lipídeos mostrou-se menor no molusco $M$. falcata, com média de 2,9\%, enquanto o A. brasiliana expressou um valor superior com média de 7,7\% e também apresentou-se mais rico nos teores de cinza (3,13\%) e carboidratos (15,18\%). A espécie $M$. falcata revelou um teor médio de 1,38\% e 8,45\% destes componentes. Quanto aos minerais, o zinco apresentou teores de maior expressão: 70,5 mg para $M$. falcata e 68,8 mg para A. brasiliana. A quantidade média de cálcio encontrada para o $M$. falcata foi de 53,7 mg e para o A. brasiliana 49,5mg, comprovando assim a importante colaboração destes bivalves como fontes de nutrientes na alimentação de populações litorâneas.

Em trabalho realizado concomitantemente a esta pesquisa, foram avaliados a composição centesimal de mexilhões Perna perna nos mesmos pontos de cultivo e período, sendo encontrado os seguintes valores para umidade, lipídeos, cinza, proteína e carboidrato: 83,9\%; 1\%; 1,9\%; 9\% e 4\% respectivamente (Porrelli et al., 2003). 


\subsubsection{Características físico-químicas da carne}

A carne de moluscos recém capturados apresenta odor típico de "fresca"; nos produtos elaborados apresenta-se leitosa, com aroma agradável. A ação de fechar as valvas quando estão em contato com o ar, a elasticidade da carne e as cores vivas são sinais de frescor (Beirão et al., 2000).

O processo de decomposição altera quase sempre a concentração de íons hidrogênio de um alimento. A determinação do $\mathrm{pH}$ é importante no caso do pescado, pois este é um alimento de baixa acidez (Tavares et al., 1988).

Um dos padrões de qualidade do pescado está baseado na análise de $\mathrm{pH}$ do produto, no qual os níveis externos do $\mathrm{pH}$ da carne aceitáveis são inferiores a 6,8 e internos 6,5. Outros índices de qualidade também são utilizados como BVT, TMA e indol (Beirão et al., 2000; Brasil, 1980; Pregnolatto \& Pregnolatto, 1985).

A medida do $\mathrm{pH}$ não deve ser utilizada individualmente como índice de frescor, pois pode induzir a falsas avaliações. No entanto, seus valores geralmente acompanham, paralelamente, análises químicas, microbiológicas e sensoriais (Nort, 1988).

Quando o pescado morre, modificações físico-químicas ocorrem em seu corpo até a completa deterioração, e estas precisam ser controladas e monitoradas ao se objetivar a qualidade do produto final. Os passos iniciais do processo de deterioração do pescado são a liberação de muco em sua superfície e a instalação do rigor mortis; a autólise e a decomposição bacteriana caracterizam o produto deteriorado (Oetterer, 1999).

Quando comparados a outros tipos de pescado, os moluscos apresentam em sua carne um teor relativamente elevado de carboidratos e menores concentrações de nitrogênio. Conseqüentemente, a sua deterioração pode ser considerada essencialmente fermentativa. Outro fator qualitativo do pescado é quanto aos lipídeos, que possuem 
grande quantidade de ácidos graxos insaturados,sendo portanto, altamente suceptíveis à oxidação acelerada pela presença de luz, calor, irradiação e metais pesados (Beirão et al., 2000).

\subsubsection{Microbiologia da carne de bivalves}

A classe Bivalva é de grande interesse para os ecologistas que se interessam pelo controle da poluição, pois é provavelmente a maior acumuladora de poluentes do meio ambiente. Esse fato tem sido objeto de estudos de avaliação de contaminação ambiental através da presença de bactérias e metais pesados em bivalves. Com o incremento da mitilicultura, os riscos sanitários causados pelo consumo de mexilhões têm aumentado no que se refere à presença de metais pesados, fitoplâncton e microrganismos (Espínola \& Dias, 1980; Lamparelli, 1987).

Os moluscos particularmente o Mytilus edulis estão entre os mais importantes animais contaminados de enseadas nas regiões temperadas. Eles também estão entre os organismos de maior dificuldade de controle, freqüentemente impondo condições que eliminam outras espécies. Entre os vários métodos usados para controle dos moluscos contaminados por poluição, a cloração é provavelmente o mais largamente utilizado (Espínola \& Dias, 1980).

Devido à sua distribuição na costa marítima e estuário, os moluscos estão por inúmeras vezes sujeitos à poluição proveniente de esgoto, principalmente nas proximidades de grandes centros urbanos. O principal perigo à poluição é a presença de bactérias e vírus patogênicos, o que se transforma em problema de saúde pública, abalando o prestígio desses alimentos junto à população; agravando o problema, está o consumo dos moluscos in natura ou levemente cozidos (Beirão et al., 2000; Espínola \& Dias, 1980; José, 1996).

Dependendo da qualidade microbiológica da água da qual é capturado e/ou cultivado o molusco, da qualidade da água que se utiliza para sua lavagem e de outros fatores, a microbiota dos moluscos bivalves varia consideravelmente. Têm-se isolado os 
seguintes gêneros bacterianos: Serratia, Pseudomonas, Proteus, Clostridium, Bacillus, Escherichia, Enterobacter, Shewanella, Lactobacillus, Flavobacterium e Micrococcus. Conforme se instala e avança a alteração, predominam as espécies de Pseudomonas, Acinetobacter e Moraxella, enquanto que nas últimas fases da alteração predominam os enterococos , os lactobacilos e as leveduras (Jay, 1994).

Nos moluscos cozidos precariamente, encontram-se espécies dos gêneros Alcaligenes, Flavobacterium, Moraxella, Acinetobacter e algumas bactérias Gram positivas. As principais bactérias patogênicas contaminantes em carnes de bivalves são a Salmonella, sempre envolvida com gastroenterites e também responsável pela febre tifóide; a Shigella que pode causar disenteria e certas espécies de Clostridium que podem produzir exotoxinas patogênicas. Moluscos são os maiores veículos do vírus da hepatite A (Espínola \& Dias, 1980; Beirão et al., 2000).

Muitos gêneros de leveduras são encontrados no pescado e produtos cárneos. Entre eles temos: Candida, Cryptococcus, Debaromyces, Hansenula, Pichia, Rhodotorula, Saccharomyces, Sporobolomyces, Torula, Torulopsis e Trichospora. (Jay, 1987).

A presença de Listeria monocytogenes classifica os produtos citados, a seguir, como de alto risco, para os quais um programa de controle de Listeria deveria ser estabelecido. São eles: os produtos cozidos ou prontos para o consumo tais como carne de caranguejo, camarão, surimi, camarão empanado, além dos consumidos in natura, bivalves e pescado defumados a frio. A natureza psicrotrófica da Listeria e outros psicrotróficos deve ser uma consideração primária de controle em qualquer tentativa de se prolongar, através de armazenagem refrigerada, a vida útil de um produto marinho (Beirão et al., 2000).

\subsubsection{Moluscos e surtos alimentares}

O consumo de moluscos, conforme registros em literatura especializada, é responsável por inúmeros surtos epidêmicos e responde diretamente pelos problemas de 
saúde pública ocasionados, principalmente, quando os moluscos são ingeridos in natura e a qualidade sanitária do ambiente aquático onde eles são capturados está comprometida (José, 1996).

Dados epidemiológicos mostram que o consumo de moluscos bivalves está associado com doenças de veiculação alimentar e a maior preocupação tem sido a água contaminada com esgoto. No entanto, moluscos bivalves podem também estar naturalmente contaminadas com Clostridium botulinum tipo E ou Vibrio spp em águas não poluídas (José, 1996).

Fonte de contaminação adicional potencial é o manejo do pescado; assim, desde o momento da captura, ainda nos barcos pesqueiros, este deve ser manipulado de forma higiênica e lavado com água livre de contaminantes. Outro fator relevante é a cadeia do frio, pois segundo algumas pesquisas, em países tropicais, as ostras têm sido comercializadas à temperatura ambiente, variando de $25^{\circ} \mathrm{C}$ a $30^{\circ} \mathrm{C}$, fomentando a contamimação inicial (Germano et al., 1998; Laloo et al., 2000).

O montante de doenças transmitidas por alimentos não é conhecido. Somente em alguns países foram estabelecidos sistemas de informações quanto a surtos de toxinfecções causadas por alimentos e, nestes, só uma pequena fração de casos é computada (World Health Organization - WHO, 1999).

A maioria dos surtos alimentares documentados, envolvendo pescado marinho nos Estados Unidos, está relacionada com o consumo de moluscos bivalves. Esta incidência se deve à biologia do animal, à qualidade da água na qual este se encontra, às técnicas de manipulação pós captura e ao fato de que estes alimentos, freqüentemente, são consumidos in natura (Cook, 1991).

A importância dos frutos do mar como veículos de toxinfecções está condicionada a fatores como a dieta da população consumidora e o modo tradicional de preparo do alimento. Assim, a proporção de surtos alimentares envolvendo pescado é significativamente mais alta no Japão devido ao alto consumo de pescado in natura quando comparado a outros países como o Canadá e Estados Unidos (Huss et al., 2000).

Segundo Laloo et al. (2000), em estudos realizados em Trinidad Tobago a respeito da qualidade bacteriológica de ostras in natura comercializadas na região, havia 
$57,5 \%$ delas na faixa das que excederam o padrão recomendado pelo ICMF International Comission on Microbiological Specifications for Foods, de 5,0 X $10^{5}$ $\mathrm{UFC/g}$ de aeróbios totais.

Do total de surtos alimentares relatados nos Estados Unidos no período de 1988-1992, 35\% foram causados por bactérias (Clostridium botulinum, Escherichia coli, Salmonella, Staphylococcus, Vibrio spp. e Bacillus cereus) através dos moluscos contaminados e 12\% através de peixes. Segundo Espínola \& Dias (1980), 47\% dos surtos alimentares, tendo moluscos como vetores, são causados por microrganismos de etiologia desconhecida, como hepatites não especificadas e certos tipos de Vibrios ( $V$. parahaemolyticus, $V$. vulnificus, $V$. cholerae), representando um risco ainda maior para pessoas que consomem bivalves in natura. No caso do $V$. parahaemolitycus, este microrganismo é responsável por uma elevação de 20\%, nos casos documentados, de intoxicação alimentar no Japão.

É possível que $V$. Cholerae possa estar associado com caranguejos e animais da fauna marinha que possuem concha, e que esta associação possa prolongar sua sobrevivência no ambiente marinho (Colwel et al., 1984).

\subsection{Considerações sobre o desenvolvimento pesqueiro brasileiro e do litoral Norte de São Paulo}

Como forma de organização social e econômica, a atividade pesqueira apresenta uma temporalidade muito antiga, apesar de estar desvinculada dos esquemas clássicos de periodização da civilização humana, até os dias de hoje, e sua importância no Brasil traduz-se a uma necessidade de maior organização dos segmentos produtivos, uma política pesqueira mais colada à realidade, um esforço maior de capacitação de pessoal e um sistema de informação mais preciso (Cardoso, 2001).

A sobrepesca de algumas espécies, a pesca predatória de outras e a destruição de ecossistemas de alta produtividade são algumas das conseqüências que 
acompanham o desenrolar do projeto de modernização do setor pesqueiro, contribuindo para a redução do pescado junto à costa (Cardoso, 2001).

Segundo dados levantados pela FAO (2003), a pesca extrativa marinha mundial teve um decréscimo de 3,45\% de 2001 a 2002, vindo este fato intensificar a importância da aqüicultura.

A categoria dos pescadores artesanais é tida como um dos grupos sociais onde predomina uma situação de pobreza, tendo havido várias tentativas para reverter tal situação, pois é predominantemente em terra e não no mar que as causas desta situação são manifestadas, refletindo situações de moradia, saneamento, nutrição, escolaridade e saúde inadequadas, presentes na maioria das comunidades pesqueiras, visto que a renda obtida pela pesca extrativa, permite somente um nível de subsistência para o pescador (Cardoso, 2001).

A cadeia de intermediação do pescado talvez seja uma das mais longas do no setor primário. Aliando-se ao fato de sua perecebilidade, enquanto mercadoria, estes fatores resultam numa brutal transferência de renda do pescador para os setores de distribuição e comercialização do produto. Também, a inconstância das capturas, inerente à pesca extrativa, compromete o rendimento dos pescadores e a organização dos processos de armazenamento e de comercialização por parte dos pescadores artesanais, impedindo-os, por exemplo, de firmarem contratos regulares de fornecimento de pescado (Cardoso, 2001).

A produção pesqueira do litoral Norte, que segundo a Companhia de Entrepostos e Armazéns Gerais do Estado de São Paulo (CEAGESP), tem caído 20 \% ao ano desde 98. A demanda existente precisa ser suprida com a compra, por parte de restaurantes, de pescado do Sul do país e do Mercosul. A queda nos estoques pesqueiros tem sido atribuída à degradação dos manguezais, à pesca predatória, e à poluição dos rios, causando uma redução de até 75\% da renda dos pescadores locais. A diminuição da renda por sua vez, tem causado abandono da profissão, fato que aliado à baixa escolaridade e pouca qualificação, acaba por dificultar o enquadramento dos pescadores em outra atividade (Fim..., 2002). 
No Brasil, a maricultura está representada, basicamente, pelo cultivo de crustáceos e moluscos. O cultivo de moluscos é responsável por 245 t. de toda a produção aqüícola mundial, sendo que os mexilhões representam cerca de 13,3\% da produção de moluscos cultivados (Ostrensky et al., 2000).

Segundo Borghetti \& Ostrensky (2000), os moluscos produzidos no Brasil são o mexilhão Perna perna, duas espécies de ostras, a nativa Crassostrea rhizophorae e a ostra do pacífico Crassostrea gigas, e uma espécie de vieria, Nodipectem nodosus.

Nestes poucos anos da mitilicultura no Estado de Santa Catarina, cerca de 800 produtores ingressaram na atividade, foram criadas 13 associações de produtores e construídas 4 unidades de processamento de moluscos. O número de empregos diretos gira em torno de 4000 e cada hectare de cultivo de mexilhão tem possibilitado a geração de até 52 empregos (Moluscos..., 2002).

\subsubsection{A aqüicultura no município de Ubatuba, SP}

No litoral Norte de São Paulo, principalmente no município de Ubatuba, estudos de custo e benefício da mitilicultura mostraram viabilidade econômica, com investimentos e custo operacional relativamente baixos. A atividade foi iniciada na região nos primórdios dos anos 70, tendo hoje uma tecnologia definida e utilizada por 18 núcleos de produção, sendo 10 destes no município de Ubatuba, na sua maioria formados por comunidades de pescadores artesanais (Brasil, 2002; Marques \& Pereira, 1989; Proença et al., 2001).

A mitilicultura vem sendo praticada comercialmente em Ubatuba desde 1983, porém sem um apoio político necessário ao seu desenvolvimento. Em contrapartida, no estado de Santa Catarina, onde houve grande empenho para o desenvolvimento da atividade, o cultivo do mexilhão Perna perna teve início em 1986 e já responde por cerca de 93\% da produção nacional de mexilhões (Brasil, 2002; Proença et al., 2001). 
O Litoral Norte de São Paulo possui uma área de $1943 \mathrm{~km}^{2}$ abrangendo quatro municípios: São Sebastião, Ilhabela, Caraguatatuba e Ubatuba. Estes municípios possuem um total de 184 praias, a maioria com extensão média de $1 \mathrm{Km}$, cobrindo uma extensão de 128 km (CETESB, 2002).

O município de Ubatuba é constituído de 78 praias e segundo dados do IBGE - Censo 2000, possui a população de 66.448 habitantes, sendo que este número é praticamente duplicado nos finais de semana prolongados e na alta temporada. Sendo que, segundo Salati Filho (2001), a carga poluidora média da população fixa é de 2.691 $\mathrm{Kg} \mathrm{DBO} /$ dia, enquanto que o da população flutuante principalmente nos finais de semana e férias é de $8.073 \mathrm{Kg} \mathrm{DBO} /$ dia, chegando ao máximo de produção de carga poluidora de $13.455 \mathrm{Kg} \mathrm{DBO} /$ dia.

Quatro municípios do Litoral Norte do Estado de São Paulo são atendidos pela Companhia de Saneamento Básico do Estado de São Paulo - SABESP, mas apenas as áreas centrais possuem rede de coleta de esgoto, cujo tratamento ou desinfecção é feita à base de cloro. Nas praias existem alguns sistemas individuais de tratamento de esgotos e a disposição final é feita por infiltração no solo através de fossas sépticas ou pelo lançamento em corpos d’água (rios, córregos e oceano), após desinfecção (Salati Filho, 2001).

Segundo a Companhia de Tecnologia de Saneamento Ambiental - CETESB (2003), os índices relativos do Litoral Norte referentes a esgoto impressionam não só pela quantidade de carga poluidora gerada mas, sobretudo, pela quantidade não tratada cerca de $90 \%$.

Os resultados de análises efetuadas por Agudo et al. (1982), revela que, algumas praias do município de Ubatuba apresentaram índices crescentes de contaminação nos últimos anos. A mais prejudicada tem sido a praia do Saco da Ribeira, onde a concentração de coliformes fecais aumentou em um fator 23, nos últimos três anos, passando de uma concentração mediana de $1,0 \times 10^{2} \mathrm{CF} / 100 \mathrm{~mL}$ para 2,3×10 3 CF/100 mL. Outras praias do município, onde o nível de poluição vem aumentando em menos proporção são Praia das Toninhas, Praia da Enseada, Praia de Perequê-Mirim, Praia do Lázado e Praia Dura. Já nas praias de Itamambuca, Vermelha do Norte, 
Perequê-Açu, Tenório, Itaguá, Praia Grande, Lagoinha e Maranduba, nos últimos três anos, o nível de poluição pode ser considerado estável. A Praia Iperoig tem sido considerada através dos anos como uma das mais contaminadas de todo o município, porém com leve tendência a melhorar nos últimos anos. Relatórios recentes da Cetesb, revelam que a qualidade das águas das praias do Litoral Paulista melhoraram em 2002; a tendência de melhora na qualidade sanitária da praia paulistas vem se verificando nos últimos 4 anos, fato explicado em parte, pelas obras de infra-estrutura de saneamento básico implantadas na região costeira (Relatório..., 2003).

O município de Ubatuba é considerado um local excelente para implantação da maricultura, pois situa-se, relativamente, próximo aos principais centros consumidores (São Paulo e Rio de Janeiro); é uma região com muitos atrativos turísticos; apresenta a costa litorânea bastante recortada, formando pequenas baías abrigadas e possui $80 \%$ de sua área inserida no Parque Estadual da Serra do Mar (CETESB, 2002).

O turismo no Litoral Norte teve grande incremento a partir da década de sessenta, com o advento das ligações rodoviárias, promovendo o afluxo de turistas para esta região. À problemática do desenvolvimento urbano e turístico do litoral, soma-se a problemática ambiental que ganha corpo nas últimas décadas.

Como já sugerido pela FAO (2001), a aqüicultura vem destacando-se como provedora de alimentos e empregos, o que pode ser confirmada, pela adesão de pescadores locais à maricultura. Segundo entrevista à Folha de São Paulo (Fim... 2002), o pescador Euzébio Higino de Oliveira, 58 anos, produtor de um dos pontos de coleta da presente pesquisa, afirma estar satisfeito com a produção de mexilhões, pois, segundo o mesmo, em época de temporada, o faturamento com a venda dos moluscos chega a R\$ 2.000,00, enquanto que com a pesca extrativa ganhava não mais do que um salário mínimo.

Nos laboratórios do Centro de Biologia Marinha da USP (Cebimar - USP) e Instituto de Biociências da USP, estudos de monitoramento da presença de toxinas marinhas, iniciaram-se em meados da década de oitenta, constatando a existência das 
mesmas no litoral de São Paulo, porém em quantidades residuais, sem oferecer perigo aos consumidores de mariscos (Freitas, 2003).

\subsubsection{A atividade da mitilicultura}

A problemática da produção de mexilhões como atividade extrativa no que se refere aos aspectos sanitários, de legislação e de saúde do consumidor foi discutida por José (1996), para os municípios paulistas de Peruíbe, São Sebastião e São Paulo. As conclusões são as seguintes: a legislação pertinente é inadequada e incompleta, uma vez que não abrange diversos procedimentos inerentes à obtenção de bivalves para consumo humano; a atuação dos órgãos públicos responsáveis pela fiscalização sanitária das áreas de obtenção de bivalves é falha no que se refere aos serviços de inspeção e fiscalização de alimentos em nível federal, estadual e municipal; a inexistência de um dispositivo legal a respeito da obrigatoriedade de identificação de bivalves, inviabiliza o conhecimento da área de origem por ocasião da comercialização e, esta ocorre de forma rotineira no Estado de São Paulo, no atacado e no varejo; inúmeros comerciantes adquirem bivalves sem comprovação de origem, tornando-se responsáveis pela sanidade dos mesmos; os comerciantes varejistas infringem o Código do Consumidor, por não divulgarem que bivalves provenientes de água com concentração média superior a 14 Coliformes fecais CF/100mL não podem ser ingeridos in natura e por não informarem as condições sanitárias do local de origem do produto por eles comercializado; os próprios consumidores, que adquirem esses produtos sem identificação, demonstram falta de conhecimento do risco à Saúde Pública e de conscientização dos próprios direitos.

${ }^{27}$ Segundo Ostini \& Gelli (s/d) há vários métodos de cultivo de mexilhões. Dentre eles está o cultivo em estaca que é muito utilizado na França e apresenta a vantagem de não expor os bivalves aos predadores do fundo; a desvantagem é a exposição ao ar na maré baixa, reduzindo o tempo hábil de alimentação. O cultivo sobre

${ }^{27}$ OSTINI, S; GELLI, V.C. Curso de criação de mexilhão. Ubatuba: IPESCA, s.d. 45p. 
o fundo é uma técnica muito utilizada na Holanda e consiste no transporte de mexilhões jovens para os locais de cultivo, geralmente em águas calmas e rasas, a vantagem deste sistema é que o marisco permanece todo o tempo submerso, alimentando-se continuamente, mas tem como maior desvantagem o contato deste com o lodo e, conseqüente presença de resíduos minerais no intestino, depreciando o produto final. Para a implantação do cultivo suspenso, muitos aspectos devem ser levados em consideração, embora seja uma técnica muito utilizada no Mediterrâneo, com a vantagem de apresentar baixo custo de implantação e manutenção.

No Litoral Norte de São Paulo existem 77 famílias cadastradas como produtoras de mexilhão Perna perna. Os criadores estão organizados em associações, e as fazendas marinhas estão localizadas em 23 praias ao longo do litoral. Cada fazenda ocupa cerca de $2.000 \mathrm{~m}^{2}$ de lâmina d'água e produz em média $12 \mathrm{Kg}$ de mexilhão por metro linear de rede (Gelli et al., 2002).

O sistema de cultivo utilizado pelos produtores no Litoral Norte é denominado espinhel, ou “long line”, devido a sua adaptação às condições oceanográficas da Costa paulista, que permitem fácil manejo e pequeno investimento. A semeadura é realizada com base no sistema francês, permitindo que cada sistema simples implantado produza até duas toneladas de mexilhões, em casca, por safra e em um período que varia de 6 a 9 meses, conforme o local de produção (Pereira et al., 2003).

As técnicas de criação de mexilhões foram aprimoradas e difundidas pelo Instituto de Pesca/ Agência Paulista de Tecnologia do Agronegócio - APTA/ Secretaria da Agricultura e Abastecimento - SAA e suas parcerias (Centro de Assistência Técnica Integrada (CATI) - São Sebastião e Departamento de Produção Animal - DPA/ Ministério da Agricultura, Pecuária e Abastecimento - MAPA) através de cursos e assistência técnica a comunidades de pescadores locais do Litoral Norte do Estado de São Paulo, resultando no aumento de 9 para 90 produtores nos últimos cinco anos (Gelli \& Carneiro, 2003). Sendo que, o município de Ubatuba conta com 42 mitilicultores.

A Associação dos Maricultores do Estado de São Paulo -AMESP é composta de 115 associados. A implantação do sistema de geo-referenciamento para a 
implantação da maricultura, a padronização do cenário e o zoneamento das fazendas marinhas, são ações coordenadas pelo Instituto de Pesca, com a participação das demais parcerias (Secretaria do Meio Ambiente, Instituto Brasileiro do Meio Ambiente e dos Recursos Renováveis - IBAMA, DPA/ MAPA, colônias de pesca, prefeituras municipais e universidades) que estão propiciando o desenvolvimento ordenado das fazendas mexilhoneiras na região (Gelli \& Carneiro, 2003).

Estes mesmos autores realizaram um levantamento preliminar em 1989, quanto às áreas mais favoráveis à mitilicultura no litoral do município de Ubatuba e concluíram que a atividade pode ser praticada no município, em cerca de 4100 hectares distribuídos ao longo deste litoral; que o potencial de produção desta área é, de acordo com as mesmas estimativas, de cerca de 125 mil toneladas de mexilhões, em casca, por ano, e que, do ponto de vista econômico, esse potencial justifica plenamente a delimitação e a preservação destas áreas para fins de prática da mitilicultura.

Atualmente, a produção de mexilhão do Litoral Norte está em torno de 100 toneladas/ano, sendo o município de Ubatuba, o local com maior potencial de produção. A comercialização do mexilhão ocorre praticamente durante o ano todo, predominando a forma a granel, sendo que a oferta é maior no verão, período em que a produção é maior. A maioria dos produtores de Ubatuba vende o mexilhão in natura, vivo na concha, sendo que alguns os vendem limpos e cozidos e outros comercializam o produto já pronto para o consumo - "mariscado", diretamente na praia para o turista. Todas as iniciativas de criação de moluscos bivalves no país podem ser consideradas clandestinas, no que se refere à legalização de uso da área. Isso ocorre porque a legislação pertinente (Decreto 2869) permanece com suas normas complementares ainda não aprovadas, o que pode dificultar a aquisição do Registro do Aqüicultor por parte dos criadores e, conseqüentemente, de financiamentos e garantias previstas no corpo do Decreto (Pereira et al., 2003; Rinaldi et al., 2003). 


\subsubsection{Diagnóstico de mercado e consumo}

A falta de um sistema de inspeção para moluscos cultivados é um fator de restrição ao consumo. Não existe atuação da Inspeção Estadual (SISP - Serviço de Inspeção de São Paulo) para moluscos. O Estado conta apenas com duas unidades para depuração de ostras operando com o SIF -Serviço de Inspeção Federal. A implantação de unidades de beneficiamento com SIF, permite a ampliação do mercado, inclusive a comercialização em outros Estados da Federação. Também, a presença de produtos inspecionados e não inspecionados causa uma concorrência desleal no mercado, dado que as unidades inspecionadas arcam com os custos necessários para se obter a certificação (Serviço de Apoio Às Micro e Pequenas Empresas de São Paulo - SEBRAE, 2002).

Ao lado desta problemática deve-se considerar que, no país, por razões culturais e sócio-econômicas, o consumo de pescado ainda é pouco expressivo; nos últimos anos, todavia, tem-se observado uma mudança no perfil nutricional da população e a oferta de pescado de qualidade no mercado interno, pode direcionar o consumo, em especial pela oferta de novas formas de apresentação, ao consumidor, deste alimento perecível (Germano et al., 1998).

No Brasil, o universo de consumidores de pescado, pode ser dividido em dois: a população de baixa renda, que habita regiões ribeirinhas ou litorâneas e que tem no pescado a única fonte de proteínas, e a de alta renda, que deverá ter no pescado um alimento alternativo, que permitirá manter uma dieta rica em nutrientes e com baixos índices calóricos e portanto, melhor para a saúde (Espínola \& Dias 1980; Germano et al., 1998).

A comercialização dos mexilhões (mariscos) é praticada no Litoral Norte, durante todo o ano, mas concentra-se no verão, em função da chegada dos turistas. Estes são os maiores consumidores, juntamente com os restaurantes e bares locais. A forma predominante de comercialização é in natura, na concha, e o preço é ditado pelo mercado consumidor. 
O comportamento do consumidor é influenciado por variáveis sóciodemográfico-culturais, variáveis psicológicas (estilo de vida, motivação) e por situação de compra. Com relação à freqüência do consumo, 39,31\% dos paulistanos afirmam consumir moluscos poucas vezes ao ano e 26,21\% apenas nos meses do verão. Apesar do consumidor preferir em 52,08\% das vezes consumir o produto em casa, observa-se um valor relevante para o consumo em restaurantes (34,38\%) (Barni et al., 2002).

Pesquisa da EPAGRI - Empresa de Pesquisa Agropecuária e Extensão Rural de Santa Catarina, realizada em três Estados brasileiros, entre eles São Paulo, atesta-se uma clara preferência pelo produto a granel, desconchado e fresco (resfriado), no entanto, devido a sua natureza perecível e sua limitada capacidade de armazenamento, é premente o desenvolvimento de embalagens, redução dos custos de distribuição e um transporte rápido, econômico e confiável. Em 2002, os principais canais de distribuição dos moluscos na cidade de São Paulo eram: 52,82\% supermercados, $21,13 \%$ peixarias de bairro, 19,01\% mercado municipal e 3,52\% direto do produtor (Barni et al., 2002).

Atualmente, o mercado distribuidor de moluscos no Estado de São Paulo tem como característica principal, a clandestinidade. Nesse mercado, a maioria dos atravessadores comercializa o produto proveniente do extrativismo, não certificado sanitariamente, adquirido dos produtores por um preço irrisório e vendido ao consumidor com um lucro excessivo e sem qualquer garantia.

No caso do mexilhão produzido em Ubatuba, não existe nenhuma empresa que beneficie ou processe esse produto, o que obriga os produtores a comercializarem sua produção, diretamente, nos bares e restaurantes. 


\section{MATERIAL E MÉTODOS}

\subsection{Eleição e caracterização dos pontos de coleta}

A eleição dos pontos de coleta foi feita com base nas considerações discutidas a seguir.

As áreas propícias para a implantação da mitilicultura no município de Ubatuba, Estado de São Paulo, encontram-se geo-referenciadas por meio de posicionamento por satélites (Global Position System -GPS). Previamente, foram considerados os aspectos ambientais, econômicos e sociais, com a participação de órgãos, instituições governamentais e representantes das comunidades envolvidas, compartilhados com os aspectos tecnológicos dos sistemas de cultivo Todos os pontos foram fotografados, totalizando 30 pontos demarcados no município de Ubatuba (Gelli $\&$ Carneiro, 2003). Foram escolhidos, para coleta de amostras, 3 pontos de cultivo, onde a atividade já havia sido implantada e que caracterizavam-se por serem bem distintos.

Os pontos de coleta estudados encontram-se localizados nas praias da Barra

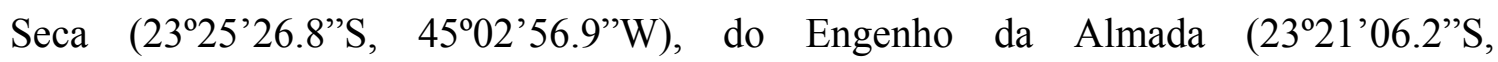

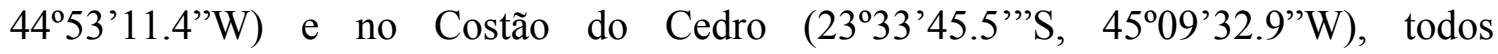
classificados como área de ocupação primária, conforme assinalado na Figura 1. 


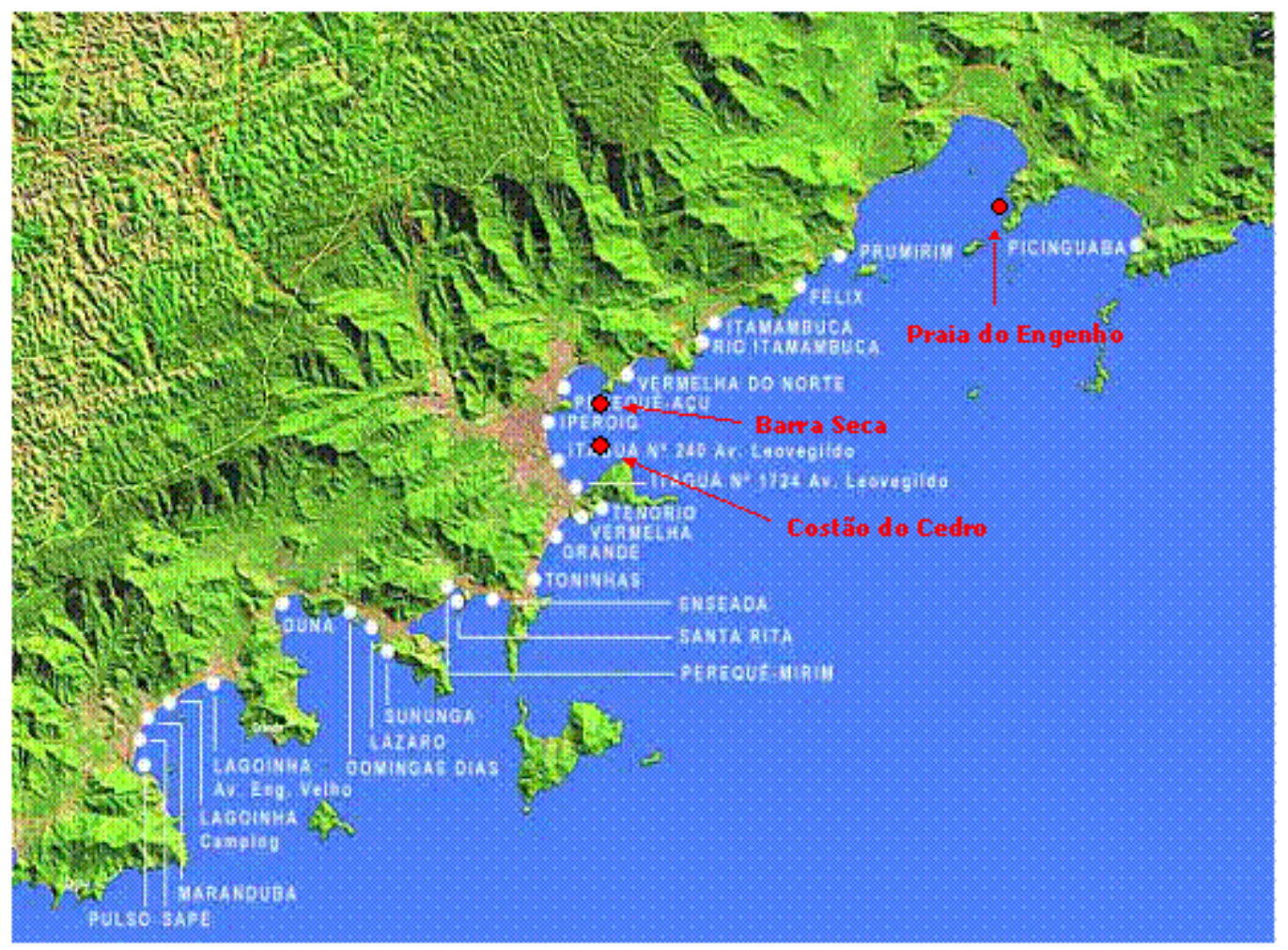

Figura 1 - Mapa referente aos pontos de coleta de Ubatuba, SP.

A Almada (Praia do Engenho da Almada) localiza-se a $44 \mathrm{Km}$ do Centro de Ubatuba, sentido Parati, é circundada pela enseada do Ubatumirim, defronte a ilha dos Porcos Pequena e aos fundos, do lado direito, avista-se a ilha do Prumirim. A região caracteriza-se pela presença de uma comunidade bastante reduzida. O cultivo localiza-se a partir de $80 \mathrm{~m}$ de distância da costa mais próxima e a região possui fossa asséptica para os efluentes domésticos (esgoto). O cultivo nesta área é feito com rede de poliestireno de $1,5 \mathrm{~m}$ de comprimento, sendo as sementes obtidas dos próprios equipamentos de produção (bóias) ou da praia Brava.

A Praia da Barra Seca localiza-se em uma região densamente povoada, separada da praia do Perequê-açú pelo rio Indaiá. O cultivo abrange uma área de 2.000 
$\mathrm{m}^{2}$, tem 5 "long lines" a uma distância aproximada de 1,5 $\mathrm{Km}$ da costa e 1,6 Km do Rio Indaiá. A maior parte das sementes é coletada na própria produção e, próximo à região, existe um berçário, a praia da Mãe Maria.

O Costão do Cedro localiza-se na região central de Ubatuba, aproximadamente a 4,0 Km da principal saída de efluentes orgânicos (esgoto), que passam por tratamento anteriormente à sua devolução ao ambiente. É uma região de mar aberto e protegido ao sul, sendo o cultivo constituído por 700 redes plantadas em cordas de 1,80 a 2,5m de comprimento, em um local onde a profundidade varia de 4,5 a 6,0m.

\subsection{Metodologia de coleta da água}

Para a coleta, foram utilizados barcos de madeira a remo, como mostra a Figura 2, cedido pelos próprios maricultores da região.

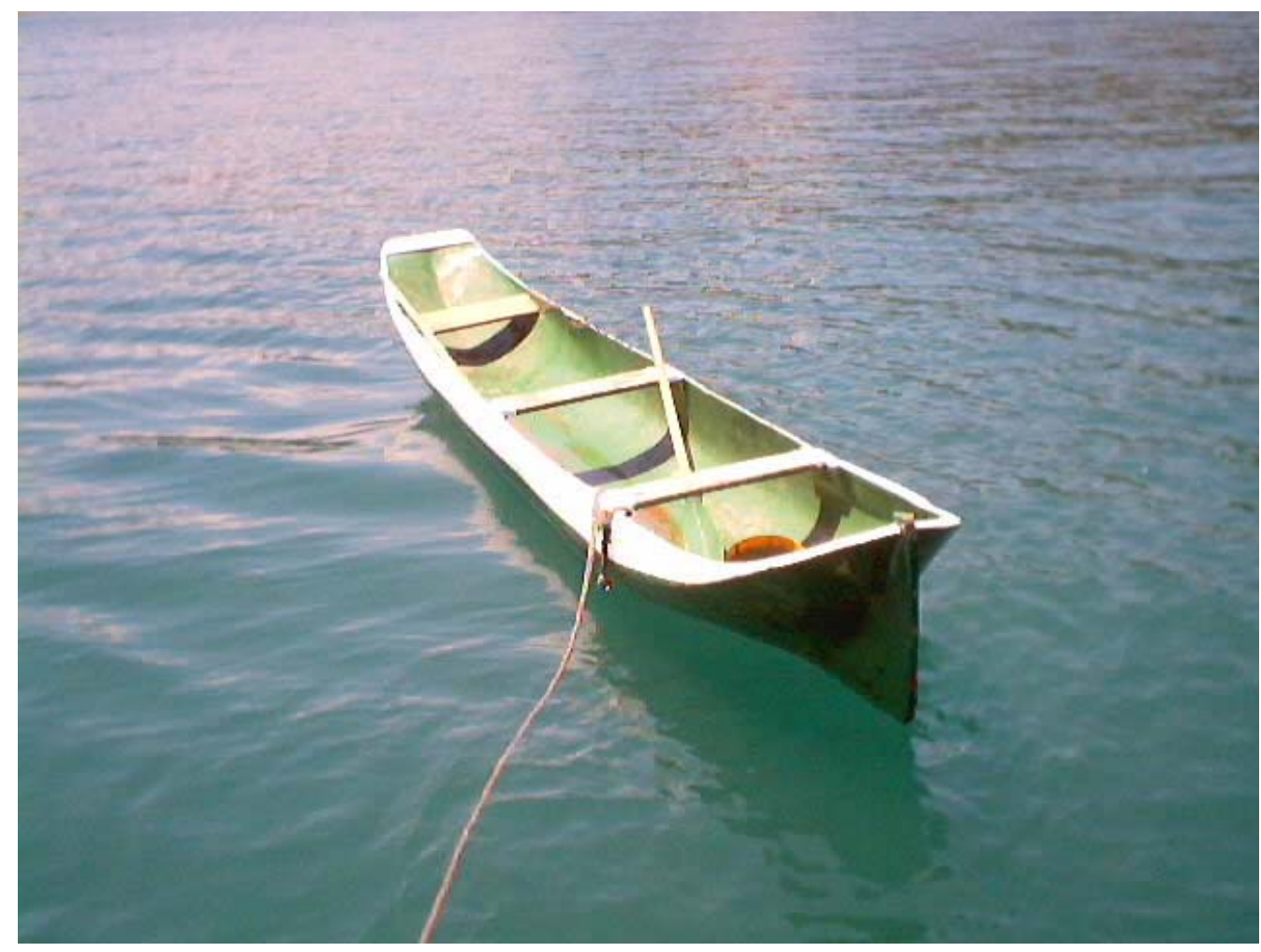

Figura 2 - Barco cedido pelos maricultures para as coletas das amostras. 
Foram utilizados frascos de vidro neutro de borossilicato com capacidade para $1 \mathrm{~L}$, os quais foram previamente envoltos em papel pardo e esterilizados por $2 \mathrm{~h}$, em estufa Fanem, modelo $315 \mathrm{SE}$, à temperatura de $170-180{ }^{\circ} \mathrm{C}$.

A coleta da água foi efetuada manualmente, seguindo recomendações da CETESB (1988). O frasco foi mergulhado, em contra corrente paralelamente ao movimento da água, cerca de 15 a $30 \mathrm{~cm}$ abaixo da superfície da água junto aos pontos de cultivo, previamente selecionadas, para evitar a introdução de contaminantes superficiais, conforme mostra a Figura 3. Inclinou-se o frasco, lentamente, para cima a fim de permitir a saída do ar e conseqüente enchimento do mesmo. Após a retirada do frasco da água, desprezou-se uma pequena porção da amostra, deixando espaço suficiente para permitir a homogeneização da amostra para análise. Estes foram devidamente etiquetados e transportados em vasilhame isotérmico, com gelo, até o local da análise (Figura 4).

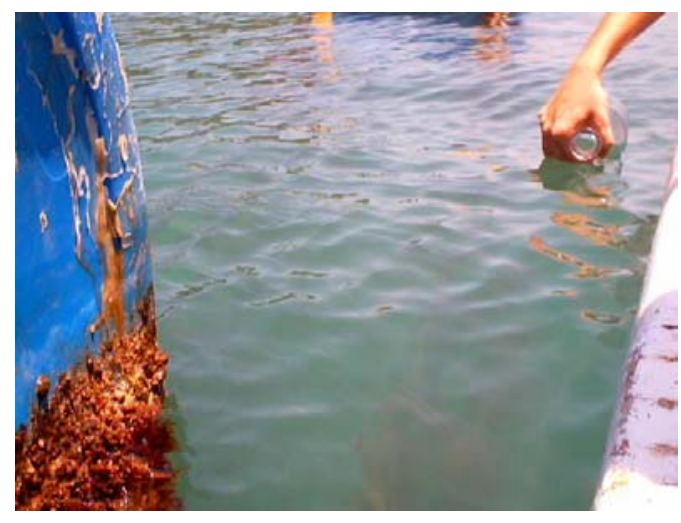

Figura 3 - Coleta da água superficial dos pontos de cultivo eleitos. 


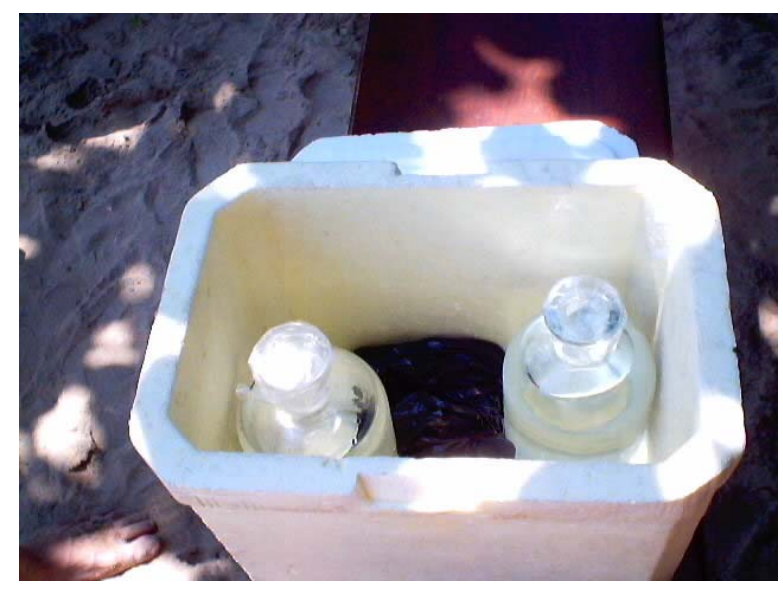

Figura 4 - Transporte das amostras de água.

\subsection{Metodologia de coleta dos mexilhões}

Cerca de $10 \mathrm{Kg}$ de mexilhões foram retirados de cada um dos pontos de coleta, referentes a, aproximadamente, uma corda de cultivo, conforme mostra a Figura 5. Estes, foram submetidos ao processo de desdobre, onde o próprio produtor tira os cachos de mexilhões das cordas e efetua a operação de retirada das cracas e parasitas (Figura 6). Posteriormente, procedeu-se à lavagem com água do mar, no caso dos mexilhões da praia do Engenho ou água tratada, pela SABESP, nos outros dois pontos (Barra Seca e Costão do Cedro), efetuando-se assim, a limpeza superficial das valvas (Figura 7). Os mexilhões foram acondicionados em sacos de fibra vegetal (ráfia), e transportados para o laboratório, em vasilhame isotérmico, contendo gelo preparado com água filtrada, na proporção de 3:1 (mexilhão/gelo) Figura 8. 

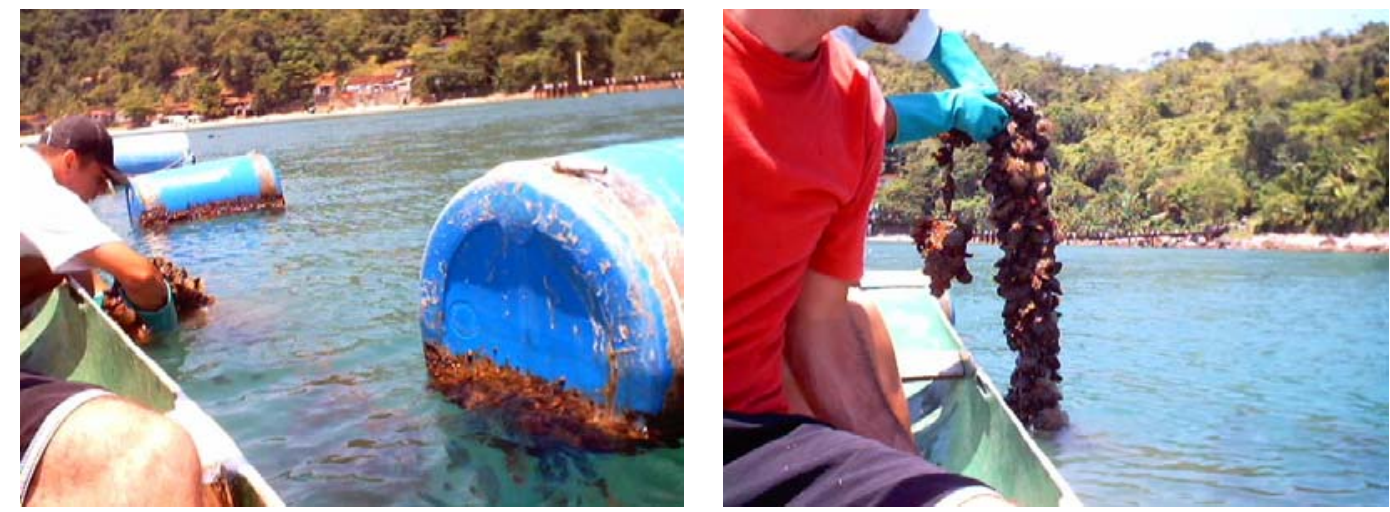

Figura 5 - Coleta dos mexilhões das cordas de cultivo "Long line".
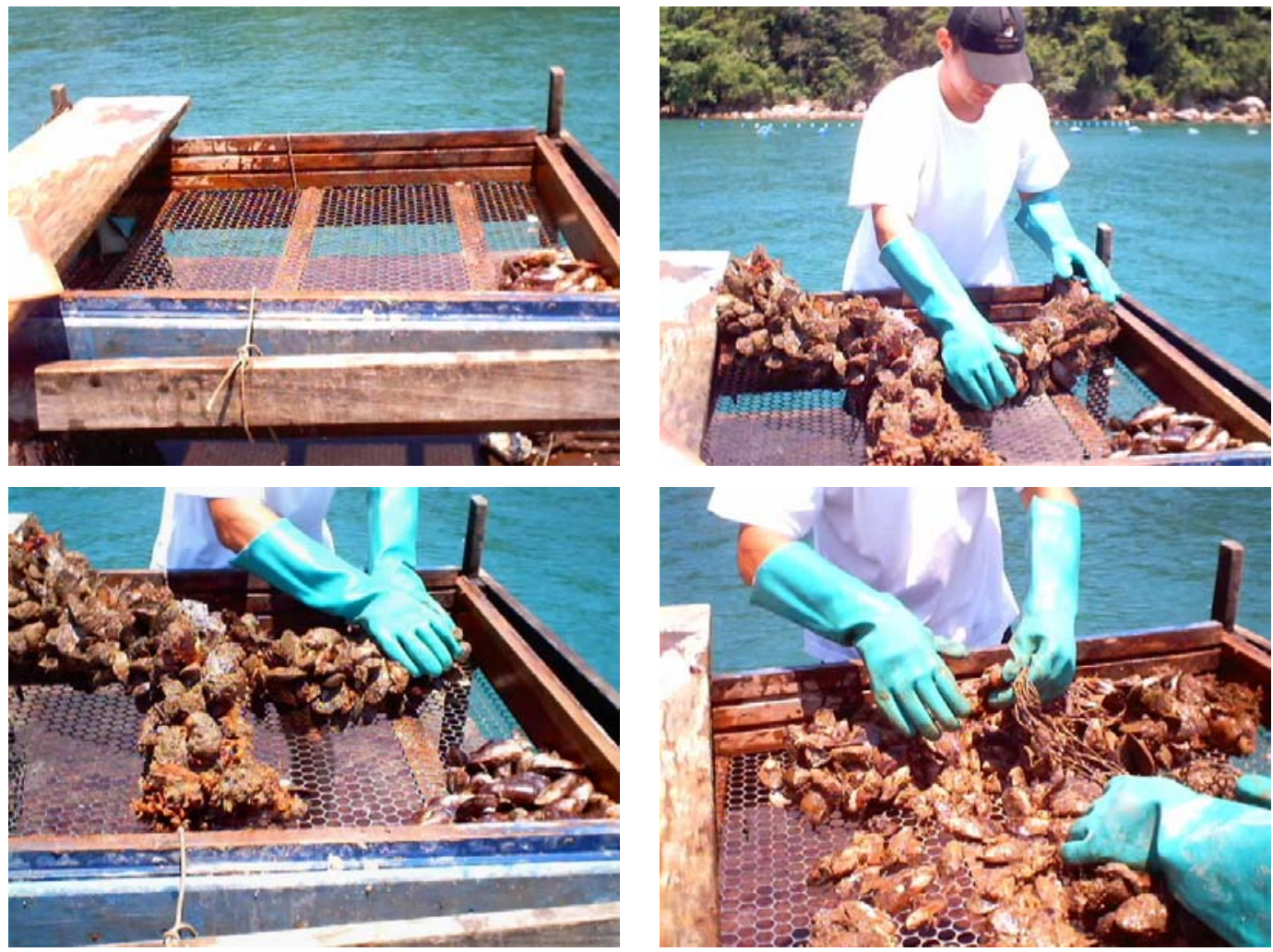

Figura 6 - Etapas da operação de desdobre. 

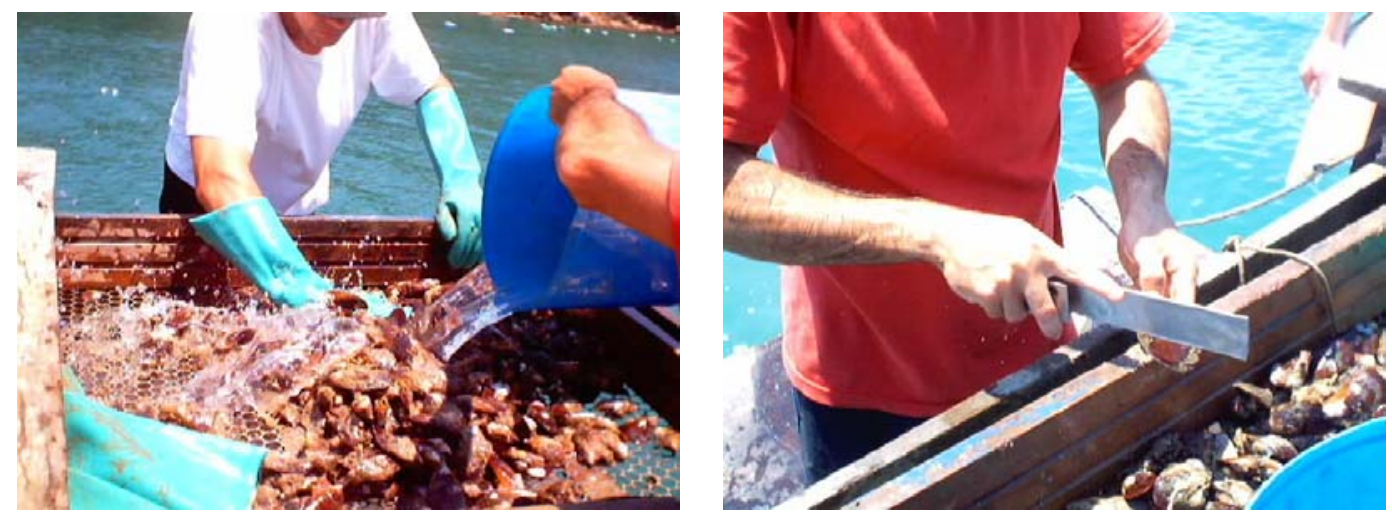

Figura 7 - Lavagem com água do mar ou água tratada (dependendo do ponto de cultivo) e retirada das cracas das valvas.

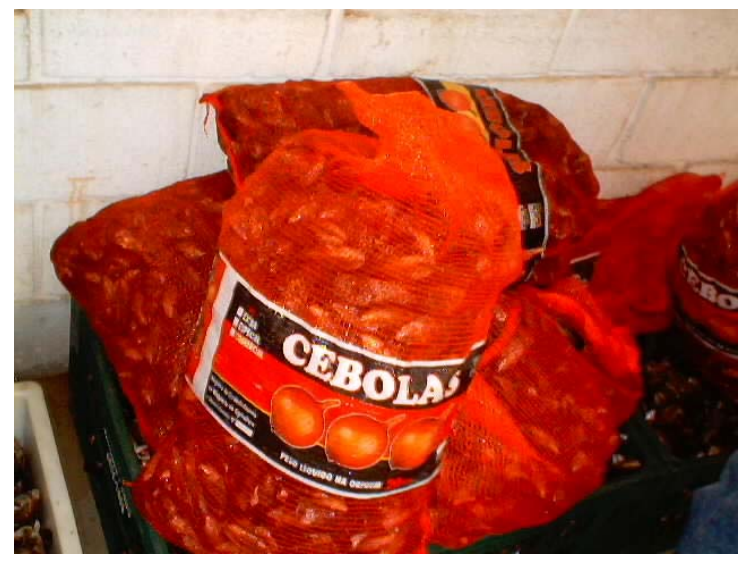

Figura 8 - Mexilhões sendo transportados em sacos de ráfia.

\subsection{Análises físico-químicas}

\subsection{1 Água de cultivo}

Para a água do mar foram analisados os seguintes parâmetros:

a) Determinação do $\mathrm{pH}$ : por leitura direta em potenciômetro Digimed. 
b) Determinação de turbidez por leitura direta em tubo de vidro em turbidímetro DLA 1000 - Del Lab, sendo os valores expressos em Unidade Nefelométrica de Turbidez UNT.

c) Temperatura, através de Termômetro Digital Pocket DT-625 (lapiseira) à prova d'água, com haste $125 \mathrm{~mm}$ e com memória min/máx.

\subsubsection{Mexilhão}

Para o mexilhão foi analisado o $\mathrm{pH}$ em potenciômetro digital.

Foram realizadas análises biométricas dos mexilhões, através das medições das valvas utilizando um paquímetro, como mostra a Figura 9.

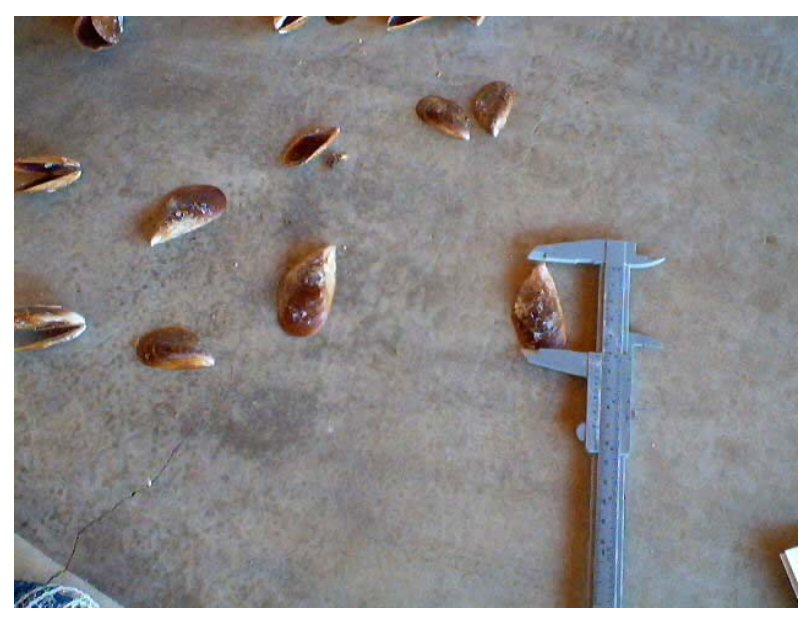

Figura 9 - Medição das valvas dos mexilhões. 


\subsection{Análises microbiológicas}

\subsubsection{Preparo das amostras de água}

Utilizou-se $25 \mathrm{~mL}$ da amostra, o qual foi adicionada de $225 \mathrm{~mL}$ de solução salina peptonada $0,1 \%$, efetuando-se a partir desta as demais diluições quantas foram necessárias, sendo as análises realizadas em triplicatas.

\subsubsection{Microrganismos analisados nas amostras de água}

\subsubsection{Coliformes totais e fecais}

Utilizou-se a técnica de tubos mútiplos, série de 3 tubos de Número Mais Provável (NMP). Para a prova presuntiva, inoculou-se $10 \mathrm{~mL}$ de água nos 3 tubos contendo Caldo Lauril Sulfato de Sódio, em concentração dupla. Inoculou-se volumes de $1 \mathrm{~mL}$ da amostra em uma série de 3 tubos contendo Caldo Lauril Sulfato de Sódio em

concentração simples, e volumes de $1 \mathrm{~mL}$ da diluição $10^{-1}$, obtida conforme descrição no item 3.5.1, em outra série de 3 tubos contendo o mesmo meio. Incubaram-se os tubos a $36^{\circ} \mathrm{C} \pm 1{ }^{\circ} \mathrm{C}$, por 48 horas. A positividade foi indicada pelo crescimento e presença de gás nos tubos de Duhram. Para a confirmação de coliformes totais, repicou-se os tubos positivos de Caldo Lauril Sulfato de Sódio para tubos de Caldo Verde Brilhante Bile 2\% lactose, que foram incubados a $36^{\circ} \mathrm{C} \pm 1^{\circ} \mathrm{C}$ por $48 \mathrm{~h}$. Para a prova confirmatória de coliformes fecais, repicou-se os tubos positivos de Caldo Lauril Sulfato de Sódio para tubos de caldo $\mathrm{EC}$, incubando-se a $45^{\circ} \mathrm{C} \pm 0,2^{\circ} \mathrm{C}$, por $48 \mathrm{~h}$ em banho-maria com agitação. A presença de gás indica positividade do tubo para a presença de coliformes fecais. Através da combinação do número de tubos positivos em cada série de diluição, nos testes para coliformes totais e fecais, e consultando-se a Tabela de Número Mais 
Provável, obteve-se NMP de coliformes fecais/mL de amostra e coliformes totais (APHA, 1998; Hitchins, et al., 2001).

\subsubsection{Enterococcus sp}

Utilizou-se a técnica de tubos mútiplos, série de 3 tubos de Número Mais Provável (NMP). Para a prova presuntiva, inoculou-se $10 \mathrm{~mL}$ da água nos tubos contendo Caldo Azida Glicose em concentração dupla. Inoculou-se $1 \mathrm{~mL}$ da amostra em uma série de 3 tubos contendo Caldo Azida Glicose em concentração simples, e volume de $1 \mathrm{~mL}$ da diluição $10^{-1}$, conforme preparo descrito em 3.5.1 em outra série de 3 tubos contendo o mesmo meio e incubou-os a $36^{\circ} \mathrm{C} \pm 1^{\circ} \mathrm{C}$ por $48 \mathrm{~h}$. A positividade foi indicada por turvação e alteração da cor de violeta, para amarelo indicando viragem do pH por produção de ácido. Para a prova complementar, utilizou-se o crescimento em caldo Ethyl Violet Azide Broth - EVA.

Para prova confirmatória efetuou-se os seguintes testes:

- Coloração de Gram através de esfregaço da cultura com posterior identificação;

- Prova da catalase através da transferência de cultura em ágar para uma lâmina contendo uma gota de peróxido de hidrogênio a 3\%. A formação de borbulhas indica positividade;

- Crescimento a $45^{\circ} \mathrm{C}$ através de inoculação em caldo BHI - Brain Heart Infusion, incubação a $45{ }^{\circ} \mathrm{C} \pm 0,2{ }^{\circ} \mathrm{C}$ por $24 \mathrm{~h}$. A turvação do meio indica positividade;

- Crescimento em $\mathrm{NaCl}$ 6,5\% através de inoculação em caldo BHI com $6,5 \%$ de $\mathrm{NaCl}$, incubação a $36{ }^{0} \mathrm{C} \pm 1{ }^{\circ} \mathrm{C}$ por $24 \mathrm{~h}$. A turvação do meio indica positividade.

Através da combinação do número de tubos positivos em cada série de diluição e utilizando-se a Tabela de Número Mais Provável, realizou-se o cálculo de NMP/100mL (Hartman et al., 1992). 


\subsubsection{Clostrídios Sulfito Redutores}

Para a prova presuntiva, inoculou-se as diluições de $10^{-1}$ a $10^{-2}$, no qual o preparo está descrito no item 3.5.1, e semearam-se alíquotas de $1 \mathrm{~mL}$ em uma série de 3 tubos contendo caldo DRCM (Differential Reinforced Clostridial Broth), de cada diluição. Adicionou-se Vaspar estéril e aqueceu-se em banho-maria a $80^{\circ} \mathrm{C}$ por 5 minutos. Incubou-se os tubos a $36^{\circ} \mathrm{C} \pm 1{ }^{\circ} \mathrm{C}$ por 48 horas. Através de combinação do número de tubos positivos em cada série de diluição, no qual a positividade caracterizou-se pelo enegrecimento e pela turvação do meio de cultura. Utilizou-se a Tabela de Número Mais Provável realizando-se o cálculo de NMP de Esporos de Clostridium Sulfito-Redutores/100 mL da amostra (Brasil, 2002).

\subsubsection{Pesquisa de Salmonella sp}

Para a determinação de Salmonella, utilizou-se de $25 \mathrm{~mL}$ da amostra, ao qual adicionou-se $225 \mathrm{~mL}$ de solução salina peptonada $1 \%$ tamponada. O homogeneizado permaneceu à temperatura ambiente por $1 \mathrm{~h}$, e posteriormente foi incubado a $36^{\circ} \mathrm{C} \pm 1^{\circ} \mathrm{C}$ por 16 a $20 \mathrm{~h}$, finalizando-se assim a etapa de préenriquecimento. Para a etapa de enriquecimento seletivo, inocubou-se alíquota de 0,1 $\mathrm{mL}$ do caldo de pré-enriquecimento em caldo Rappaport Vassiliadis e de alíquotas de 1 $\mathrm{mL}$ em Caldo Selenito Cistina e Caldo Tetrationato, e incubou-se os tubos a $41^{\circ} \mathrm{C} \pm$ $0,5^{\circ} \mathrm{C}$, em banho-maria com agitação, por 24 a $30 \mathrm{~h}$. Todos os caldos utilizados para enriquecimento seletivo foram semeados em estrias na superfície de placas contendo ágar Rambach, ágar MLCB (Manitol Lysine Crystal Violet Brilhant Green Agar), ágar BPLS (Brilhant Green Phenol Red Lactose Sucrose Agar) e ágar XLD (Xylose Lisine Agar), para obtenção de colônias isoladas. Incubou-se as placas invertidas a $36^{\circ} \mathrm{C} \pm 1{ }^{\circ} \mathrm{C}$ por 18 a 24 horas. 
Foram selecionadas colônias suspeitas, com as seguintes características, em cada tipo de meio sólido seletivo:

- Ágar Rambach: vermelhas; alguns sorotipos podem se apresentar com coloração rosa claro, de cor pêssego ou amarelas;

- Ágar MLCB: negras, lisas, brilhantes e de bordas regulares, alguns sorovares podem apresentar-se de tamanho pequeno (cerca de $1 \mathrm{~mm}$ ), de cor azul intenso ou violeta;

- Ágar BPLS: incolores ou de cor rosada, translúcidas ou ligeiramente opacas;

- Ágar XLD: negras, lisas, brilhantes e de bordas regulares, com alcalinização do meio indicada pela alteração da coloração do mesmo para rosa escuro.

Para as provas preliminares, inoculou-se cada colônia suspeita em ágar TSI (Triple Sugar Iron Agar) e ágar LIA (Lysine Iron Agar), através de picada profunda e estriamento no bisel. Paralelamente, inoculou-se em ágar BHI (Brain Heart Infusion) ágar inclinado para verificação de pureza e manutenção da cepa. Incubou-se a $36^{\circ} \mathrm{C} \pm$ $1^{\circ} \mathrm{C}$ por 18 a $24 \mathrm{~h}$.

Para TSI, a reação presuntiva esperada para salmonela é bisel alcalino ou inalterado, com base amarela ou negra, com ou sem formação de gás; para LIA, o bisel é violeta e a base é violeta ou negra. Para provas complementares, partiu-se então de colônias crescidas em ágar BHI, no qual foram inoculadas as colônias com as respostas esperadas de Salmonella sp em ágar TSI e ágar LIA, e, em meios para:

- Produção de urease: através de inoculação em caldo uréia, incubação a $36^{0} \mathrm{C} \pm 1{ }^{0} \mathrm{C}$ por 24 a 30 horas ;

- Utilização de malonato: através de inoculação em caldo malonato, com incubação a $36^{0} \mathrm{C} \pm 1{ }^{\circ} \mathrm{C}$ por 24 a 30 horas, sendo que a alteração para azul indica alcalinização do meio após utilização do malonato;

- Descarboxilação da lisina: através de inoculação em caldo moeller descarboxilase estéril, incubação a $36^{\circ} \mathrm{C} \pm 1{ }^{0} \mathrm{C}$ por 24 a 30 horas. A descarboxilação da lisina é caracterizada pela alcalinização do meio, o que é demonstrado pela não alteração de cor do indicador presente; 
- Utilização de citrato: inoculação em ágar citrato de Simmons, incubação a $36^{\circ} \mathrm{C} \pm 1{ }^{\circ} \mathrm{C}$, por 24 a 30 horas, sendo que a alteração para azul indica alcalinização do meio após utilização do citrato;

- Desaminação da fenilalanina: inoculação em superfície de ágar fenilalanina, incubação a $36^{\circ} \mathrm{C} \pm 1{ }^{\circ} \mathrm{C}$ por 24 a 30 horas, adição de solução de citrato férrico a $10 \%$, sendo que a alteração da coloração para verde indica reação positiva;

- Meio SIM: inoculação através de picado em meio SIM, incubação a $36^{\circ} \mathrm{C}$ $\pm 1^{0} \mathrm{C}$ por 24 a 30 horas. A motilidade é caracterizada pela difusão do crescimento por todo o meio. A produção de $\mathrm{H}_{2} \mathrm{~S}$ é caracterizada pelo enegrecimento do meio. Após a leitura da motilidade e da producão de $\mathrm{H}_{2} \mathrm{~S}$, é feita a adição de algumas gotas de reativo de Kovac's para verificação de indol, através da formação de um anel vermelho violáceo;

- Fermentação da lactose: através de inoculação em caldo lactose 1\% acrescido de púrpura bromocresol, incubação por 30 horas, sendo a fermentação caracterizada pela alteração da coloração do caldo para amarela;

- Fermentação do manitol: através de inoculação em caldo manitol $1 \%$ acrescido de púrpura bromocresol, incubação por $36^{\circ} \mathrm{C} \pm 1{ }^{\circ} \mathrm{C}$ por 24 a 30 horas, sendo a fermentação caracterizada pela alteração da coloração do caldo para amarelo;

- Reação de VM-VP - Voges Proskauer: através de inoculação em 2 tubos de caldo VP, incubação de um dos tubos a $36^{\circ} \mathrm{C} \pm 1{ }^{\circ} \mathrm{C}$ e o segundo a $22^{\circ} \mathrm{C} \pm 1{ }^{\circ} \mathrm{C}$ por 4 dias. Leitura de VM realizada após adição de solução de vermelho de metila A resposta positiva caracteriza-se pela coloração vermelha. Após a leitura da reação de VM, foi feita a adição de solução de $\alpha$-naphtol $5 \%$ e solução de $\mathrm{NaOH}, 40 \%$, para leitura de reação de VP, sendo que a viragem de coloração para rosa escuro indica reação positiva.

Para provas confirmatórias, as colônias suspeitas de Salmonella sp, aquelas que apresentaram Uréia, Malonato Fenilalanina, Indol, Lactose e VP negativas e Lisina, Citrato, Produção de $\mathrm{H}_{2} \mathrm{~S}$, Motilidade Manitol e VM positivos, foram submetidas às seguintes provas:

- Reação de oxidase: utilizaram-se palitos de madeira estéreis para introduzir nas colônias suspeitas. Espalhou-se a cultura sobre papel de filtro impregnado 
com o reativo específico para oxidase. Em 10 a 20 segundos, havendo o aparecimento de coloração escura (azul ou vermelho intenso, dependendo do reativo empregado) caracteriza reação positiva;

- Reação de PYRase: as colônias foram retiradas com o auxílio de palitos de madeira estéreis, e procedeu-se ao espalhamento da cultura no cartão impregnado com ácido L-piroglutâmico. Três minutos após, adicionou-se solução tampão e solução de para-dimetilaminocinamaldeído. A reação positiva caracteriza-se pela coloração vermelha;

- Prova da catalase;

- Sorologia: através de soro anti-Salmonella Polivalente "O”.

São consideradas positivas as cepas que apresentaram resultados negativos para oxidase e pyrase e positivo para catalase. O resultado foi expresso como Presença ou Ausência/25 g ou mL de amostra (Bennett et al., 1999).

\subsubsection{Staphylococcus aureus}

Foram semeadas alíquotas de $0,1 \mathrm{~mL}$ da água do mar sobre a superfície seca de ágar BP (Baird Parker) na qual, previamente, adicionou-se gema de ovo e telurito $5 \%$.

Utilizou-se a técnica de espalhamento de superfície. Nos casos em que se necessitou de resultados menores do que $100 \mathrm{UFC} / \mathrm{g}$ ou $\mathrm{mL}$, distribuiu-se $1 \mathrm{~mL}$ da diluição $10^{-1}$ em 3 placas $(0,4 \mathrm{~mL}, 0,3 \mathrm{~mL}$ e $0,3 \mathrm{~mL})$. As placas foram incubadas invertidas a $36^{\circ} \mathrm{C} \pm 1^{\circ} \mathrm{C}$ por 30 a $48 \mathrm{~h}$. Selecionou-se placas que continham entre 20 e 200 colônias típicas e atípicas. Registrou-se a contagem destas colônias. Selecionaramse 3 a 5 colônias que foram semeadas em tubos contendo caldo BHI (Brain Heart Infusion). Os tubos foram inoculados a $36^{\circ} \mathrm{C} \pm 1^{\circ} \mathrm{C}$ por $24 \mathrm{~h}$.

Foram realizadas as seguintes provas confirmatórias:

- Coloração de Gram; 
- Coagulase: transferiu-se 0,3 mL de cada tudo de cultivo em BHI para tubos estéreis contendo $0,3 \mathrm{~mL}$ de plasma de coelho, incubou-se a $36^{\circ} \mathrm{C} \pm 1^{\circ} \mathrm{C}$ por $6 \mathrm{~h}$, sendo que a resultado positivo expressa-se através da formação de coágulos;

- Termonuclease: inativou-se a cultura mantida em caldo BHI, por imersão em água à ebulição, por $15 \mathrm{~min}$, preencheu-se os orifícios com cerca de $2 \mathrm{~mm}$ de diâmetro com ágar para ensaio de termonuclease ou no águar azul de toluidina - DNA. Incubou-se a $36^{\circ} \mathrm{C} \pm 1^{\circ} \mathrm{C}$, por $4 \mathrm{~h}$, ou a $50^{\circ} \mathrm{C} \pm 2^{\circ} \mathrm{C}$ por $2 \mathrm{~h} \mathrm{O}$ aparecimento de um halo rosa no ágar azul de toluidina, foi considerada uma prova positiva para termonuclease;

- Catalase.

Foram consideradas S. aureus, as colônias que apresentaram Coloração de Gram positiva, coagulase, termonuclease e catalase positivos. Considerou-se a diluição estabelecidas, nas placas submetidas à contagem para a quantificação de Staphylococcus aureus presentes, por mL da amostra (Lancette \& Tatini, 2001).

\subsubsection{Bacillus cereus}

Semeou-se alíquotas de $0,1 \mathrm{~mL}$ de água do mar em MYP-A (Mannitol Egg-Yolk Polymyxine Ágar), através da técnica de espalhamento em superfície. As placas foram incubadas invertidas a $30^{\circ} \mathrm{C} \pm 1^{\circ} \mathrm{C}$ por 30 a $48 \mathrm{~h}$. Após esse período, selecionou-se as placas, preparadas com aguar MYP, que continham entre 15 e 150 colônias rodeadas por um halo de precipitação opaca sobre um fundo róseo. Através de uma agulha microbiológica selecionou-se 3 a 5 colônias, e estas foram semeadas em tubos com ágar inclinado e incubados a $36^{\circ} \mathrm{C} \pm 1^{\circ} \mathrm{C}$ por $24 \mathrm{~h}$.

Para identificação, foram realizadas as seguintes provas:

- Coloração de Gram;

- Motilidade: inoculou-se, com a ajuda de uma agulha, tubos contendo ágar motilidade nitrato e incubou-se a $36^{\circ} \mathrm{C} \pm 1^{\circ} \mathrm{C}$, por 18 a $24 \mathrm{~h}$, sendo que o resultado positivo é representado por crescimento difuso da cultura;

- Redução de nitrato: após a leitura de motilidade, adicionou-se 2 a 3 gotas de $\alpha$-naftilamina $0,5 \%$, e 2 a 3 gotas de ácido sulfanílico $0,8 \%$. O aparecimento de 
coloração rosa indicou positividade. A coloração vermelha indicará a redução de nitrato à nitrito. $\mathrm{O}$ resultado negativo deve ser confirmado pela adição de pó de zinco. A coloração rosa indicará a não redução do nitrato, enquanto que, a não alteração de cor indica reação positiva para redução do nitrato;

- $\beta$-hemólise: efetuou-se estriamento em superficie ágar sangue de carneiro, incubou-se a $36^{\circ} \mathrm{C} \pm 1^{\circ} \mathrm{C}$, por $24 \mathrm{~h}$. A $\beta$-hemólise é caracterizada pela formação de halo translúcido ao redor do crescimento;

- Decomposição da tirosina: estriou-se a cultura em superfície de ágar tirosina inclinado, incubou-se a $36^{\circ} \mathrm{C} \pm 1^{\circ} \mathrm{C}$, por $48 \mathrm{~h}$, sendo que a decomposição da tirosina caracterizou-se por uma zona clara próximo ao crescimento;

- Crescimento rizóide: estriou-se a cultura em superfície de ágar nutriente, incubou-se a $36^{\circ} \mathrm{C} \pm 1^{\circ} \mathrm{C}$, por 48 a $72 \mathrm{~h}$, sendo que o resultado positivo para crescimento rizóide se caracteriza pelo aparecimento de colônias com longas extensões em forma de raízes ou longos fios;

- Presença de corpúsculos de inclusão cristalina: realizou-se o esfregaço, a partir do ágar estoque inclinado mantido em temperatura ambiente por 2 a 3 dias, coloriu-se com azul de Coomasie, por 3 minutos, sendo que o resultado positivo se deu pelo aparecimento de cristais tetragonais.

São considerados como B. cereus, as colônias que apresentarem bastonetes curtos Gram positivos, com extremidades quadradas dispostos em cadeias e esporos centrais ou sub-terminais; motilidade positiva para 50 a $90 \%$ dos casos; redução de nitrato, $\beta$-hemólise, decomposicão da tirosina positivos, crescimento rizóide e corpúsculos de inclusão cristalina negativos.

Os resultados foram expressos em UFC/ml da amostra (Harmon et al., 1992; Rhodeamel \& Harmon, 1995).

\subsubsection{Microrganismos aeróbios mesófilos (heterotróficos)}

Adicionou-se de $1 \mathrm{~mL}$ em placas estéreis de cada diluição utilizada, conforme descrito em 3.5.1. Adicionou-se cerca de $20 \mathrm{~mL}$ de PCA (Plate Count Ágar) 
fundido e resfriado a $46^{\circ} \mathrm{C}$. As placas foram incubadas invertidas a $36^{\circ} \mathrm{C} \pm 1^{\circ} \mathrm{C}$ por $48 \mathrm{~h}$. Selecionaram-se placas que continham entre 25 e 250 colônias para amostras de alimentos e entre 30 e 300 colônias para amostras de água do mar. Considerando a diluição da placa submetida à contagem, efetuou-se o cálculo de microrganismos aeróbios mesófilos, estritos e facultativos viáveis presentes por $\mathrm{mL}$ da amostra (APHA, 1998; Morton, 2001).

\subsubsection{Contagem de bolores e leveduras}

Preparou-se as diluições de $10^{-1}$ a $10^{-2}$ e semeadura de alíquotas de $0,1 \mathrm{~mL}$ sobre a superfície seca de ágar batata glicose $2 \% \operatorname{com} \mathrm{pH} 3,5$, acidificado com ácido tartárico a 10\%. Espalhou-se o inóculo através da técnica de espalhamento em superfície. Utilizou-se o mínimo de duas diluições decimais ou duplicata da mesma diluição. Quando necessário a obtenção de resultado menor que $100 \mathrm{UFC} / \mathrm{g}$ ou mL, distribuia-se $1 \mathrm{~mL}$ da diluição $10^{-1}$ em 3 placas $(0,4 \mathrm{~mL}, 0,3 \mathrm{~mL}$ e 0,3 mL). Incubou-se as placas, sem inverter, a $25^{\circ} \mathrm{C} \pm 1^{\circ} \mathrm{C}$ por 5 a 7 dias, em incubadora de B.O.D. Foram selecionadas as placas que continham entre 15 e 150 colônias. Considerando a diluição da placa submetida à contagem, realizou-se o cálculo de bolores e leveduras presentes, por $\mathrm{mL}$ da amostra em análise.

\subsubsection{Preparo das amostras de mexilhões}

As amostras foram manipuladas em câmara de fluxo laminar, sendo as valvas, previamente à sua abertura, higienizadas com solução de ácido peracético $0,02 \%$.

A carne juntamente com o líquido intravalvar foram retirados da valva e depositados em becker de $1 \mathrm{~L}$, até atingir o peso de $250 \mathrm{~g}$ como mostra a Figura 10. A amostra foi homogeneizada em "stomacher" Seward até apresentar aspecto homogêneo (cerca de 2-3 minutos). Para todas as análises, pesou-se $25 \mathrm{~g}$ da amostra homogeneizada, adicionou-se $225 \mathrm{~mL}$ de solução salina peptonada a $0,1 \%$, sendo esta mistura homogeneizada novamente em "stomacher" por 60 segundos. A partir da diluição $10^{-1}$, 
foram feitas as diluições decimais subseqüentes, tantas quanto necessário para as contagens, sendo as análises realizadas em duplicata.

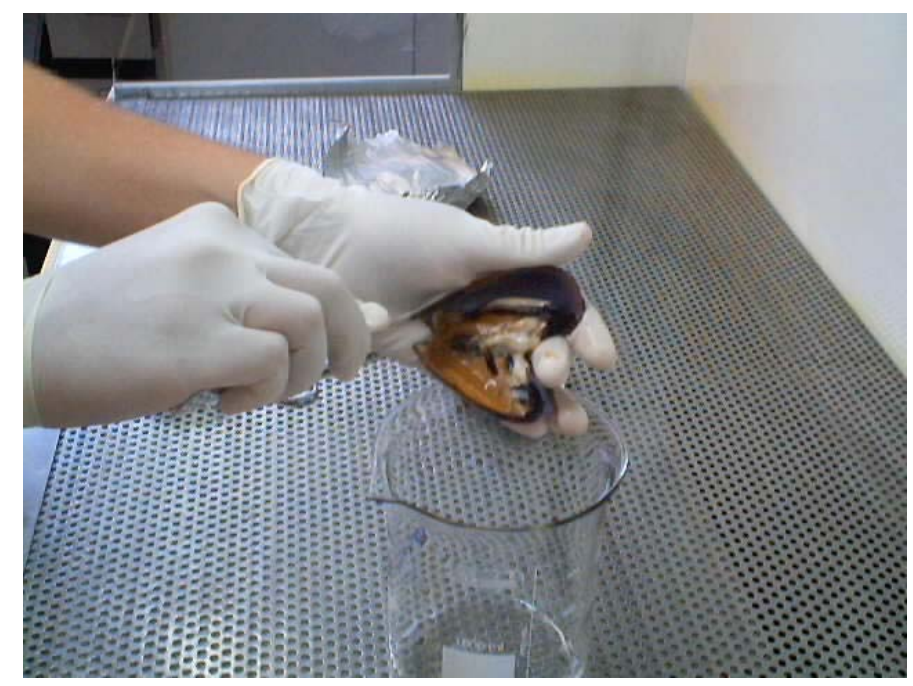

Figura 10 - Abertura das valvas e retirada da carne.

\subsubsection{Microrganismos analisados nas amostras de mexilhão}

\subsubsection{Coliformes totais e fecais}

Para a análise do número mais provável de coliformes totais e fecais, foi utilizada a técnica dos tubos múltiplos, série de 3 tubos. Para a prova presuntiva, preparou-se diluições de $10^{-1}$ a $10^{-4}$ e semeou-se alíquotas de $1 \mathrm{~mL}$, em uma série de 3 tubos, contendo Caldo Lauril Sulfato de Sódio para cada diluição. Incubaram-se os tubos a $36^{\circ} \mathrm{C} \pm 1^{\circ} \mathrm{C}$ por 48 h. O restante segue como descrito em 3.5.2.1.

\subsubsection{Enterococcus sp}

Para a prova presuntiva, efetuou-se diluições de $10^{-1}$ a $10^{-3}$ e foram semeadas alíquotas de $1 \mathrm{~mL}$, em uma série de 3 tubos, contendo Caldo Azida Glicose, 
de cada diluição. Incubou-se os tubos a $36^{\circ} \mathrm{C} \pm 1^{\circ} \mathrm{C}$, por $48 \mathrm{~h}$. O restante segue como o descrito em 3.5.2.2.

\subsubsection{Clostrídios sulfito redutores}

Foi utilizada a técnica de semeadura em profundidade, inoculando-se $1 \mathrm{~mL}$ da amostra diluída de $10^{-1}$ a $10^{-2}$ (obtidas conforme o item 3.5.1) em placas de Petri previamente esterilizadas. Adicionou-se cerca de $15 \mathrm{~mL}$ de ágar TSC (Tryptose Sulphite Cycloserine Ágar) fundido, resfriado previamente a $46^{\circ} \mathrm{C}$. Após solidificação, adicionouse uma segunda camada de cerca de $10 \mathrm{~mL}$ do mesmo meio. Incubou-se as placas sem inverter em jarra geradora de anaerobiose Anaerocult da Merck a $36^{\circ} \mathrm{C} \pm 1^{\circ} \mathrm{C}$, por 18 a 24 horas. Selecionaram-se placas que continham entre 20 e 200 colônias típicas (negras, e de tamanho de 1 a $3 \mathrm{~mm}$ ), nas quais foram realizadas a contagem. Os resultados foram expressos em UFC/g (Labbe, 2001; Rhodehamel \& Harmon, 2001).

\subsubsection{Clostridium perfringens}

Continuando a partir do item 3.5.4.3, utilizou-se para caracterizar o $C$. perfringens as seguintes provas de identificação:

- Coloração de Gram;

- Fermentação tempestuosa: a partir da trandferência de $1 \mathrm{~mL}$ da cultura obtida no caldo de carne cozida para um tubo com meio de leite com ferro. Adição de selo estéril e incubação a $46^{\circ} \mathrm{C} \pm 1{ }^{\circ} \mathrm{C}$ em banho-maria, por até 6 horas, verificou-se como teste positivo a coagulação do leite com formação de coágulo firme e grande quantidade de gás;

- Motilidade;

- Redução do nitrato;

- Fermentação da lactose e liquefação da gelatina através da inoculação com agulha em meio lactose-gelatina, no qual foi incubada em anaerobiose a $36^{\circ} \mathrm{C} \pm 1^{\circ} \mathrm{C}$ por 44 h, após a incubação, os tubos foram resfriados em geladeira por 1 hora. Os testes 
positivos são aqueles em que observa-se a fermantação da lactose pela produção de bolhas de gás e a mudança da cor do meio de vermelho para amarelo, e a liquefação da gelatina através da permanência do estado líquido após resfriamento;

- Fermentação da rafinose através da repicagem em tubo contendo caldo para fermentação da rafinose (1\%), adicionou-se de 1 a $2 \mathrm{~mL}$ de Vaspar estéril e incubou-os a $36^{\circ} \mathrm{C} \pm 1{ }^{\circ} \mathrm{C}$ por 72 horas. Considerou-se positivo para fermentação da rafinose pela viragem da cor do indicador vermelho de fenol para amarelo;

São considerados como $C$. perfringens as colônias que apresentarem bastonetes retos Gram positivos, com extremidades arredondadas; storm test positivo; motilidade negativa; redução de nitrato,fermentação da lactose e da rafinose positiva e liquefação da gelatina.

Considerando a diluição da placa submetida a contagem, é realizado o cálculo de C. perfringens/ por g da amostra em análise

\subsubsection{Pesquisa de Salmonella sp}

Idem ao item 3.5.2.4, utilizando -se $25 \mathrm{~g}$ de amostra de mexilhão.

\subsubsection{Contagem de Staphylococcus aureus}

Para esta análise foram utilizadas as diluições $10^{-1}$ e $10^{-3}$, (conforme descrito no item 3.5.3) sendo que o restante segue da mesma maneira como descrito no item 3.5.2.5.

\subsubsection{Bacillus cereus}

Para esta análise foram utilizadas as diluições $10^{-2}$ e $10^{-3}$, sendo que o restante segue da mesma maneira como o descrito no item 3.5.2.6. 


\subsubsection{Microrganismos aeróbios mesófilos (Heterotróficos)}

Para esta análise foram utilizadas as diluições $10^{-2}$ e $10^{-5}$ (conforme descrito no item 3.5.3), sendo que o restante segue da mesma maneira como descrito no item 3.4.2.7.

\subsubsection{Contagem de bolores e leveduras}

Para esta análise foram utilizadas as diluições $10^{-1}$ e $10^{-4}$ (conforme descrito no item 3.5.3), sendo que o restante segue da mesma maneira como o descrito no item 3.5.2.8.

\subsection{Análise estatística}

Tanto para água como para os mexilhões, foi estabelecida a correlação de Coliformes totais, fecais e Enterococcus sp com outros microrganismos estudados nos determinados pontos de cultivo supra citados, através do auxílio do Excel.

Foi correlacionado também as contagens microbiológicas com os índices pluviométricos, de insolação diárias e tábua de marés para averiguar a relação e interferência das variações sazonais com a contagem microbiana na água.

Os dados das análises físico-químicas tanto da água quanto do mexilhão foram avaliados segundo delineamento em blocos casualizados e submetidos a teste de análise de variância e Teste de Tukey para comparação das médias, utilizando o programa estatístico SANEST segundo Pimentel-Gomes (1990). 


\section{RESULTADOS E DISCUSSÃO}

\section{1 Água de cultivo}

\subsubsection{Análises físico-químicas}

\subsubsection{1 pH}

O valor médio do $\mathrm{pH}$, dos respectivos pontos de coleta estudados, variou de 8,23 a 8,65, conforme a Tabela 1. Segundo a CETESB (1978) o pH abaixo de 8,0 sinaliza a presença de esgoto doméstico despejado no local, conseqüentemente, trazendo grande quantidade de matéria orgânica biodegradável, sendo que a liberação de $\mathrm{CO}_{2}$ durante a decomposição de matéria orgânica em águas intermediárias e de fundo, resultam no abaixamento do $\mathrm{pH}$.

Os dados encontrados nesta pesquisa estão todos de acordo com a legislação para águas Classe 5, onde o pH deve estar entre 6,5 a 8,5, não devendo ultrapassar 0,2 unidades do $\mathrm{pH}$ natural (Brasil, 1986). As médias dos pontos de cultivo, nos referidos meses de coleta, não diferiram entre si significativamente, como mostra a Tabela 1, já quando levamos em conta o fator meses; alguns valores diferiram entre si 
significativamente; novembro e março tiveram as menores médias e diferiram dos demais, sendo que em fevereiro, ocorreu o valor médio mais alto como mostra a Tabela 2 , certamente como resultado do final de temporada.

Segundo Pinheiro Junior (2000), há uma tendência do pH da água decrescer com o distanciamento da fonte poluidora de despejo de esgoto, isto porque a matéria orgânica em suspensão é diluida pela ação das ondas, marés e correntes marinhas.

Tabela 1. pH em amostras de água do mar, referente ao fator praias.

\begin{tabular}{cccc}
\hline Pontos de Cultivo & Almada & Barra Seca & Costão do Cedro \\
\hline 8,46 a & 8,40 a & 8,44 a \\
\hline
\end{tabular}

Nota: Valor de F para fator praias $=1,07$

Coeficiente de variação $=1,10 \%$

Médias seguidas da mesma letra não diferem entre si ao nível de $5 \%$ de probabilidade

Valores médios de duplicatas

Tabela 2. pH em amostras de água do mar, segundo os meses de coleta.

\begin{tabular}{cccccc}
\hline Meses & Novembro & Dezembro & Janeiro & Fevereiro & Março \\
\hline & $8,26 \mathrm{~b}$ & $8,51 \mathrm{a}$ & $8,5 \mathrm{a}$ & $8,65 \mathrm{a}$ & $8,23 \mathrm{~b}$ \\
\hline
\end{tabular}

Nota: Valor de F para fator praia $=1,07$

Coeficiente de variação $=1,10 \%$

Médias seguidas da mesma letra não diferem entre si ao nível de $5 \%$ de probabilidade

Valore médios de duplicatas 


\subsubsection{Turbidez}

A média geral das coletas ficou em torno de 0,67 UNT - Unidade Nefelométrica de Turbidez, alcançando picos de 1,15 UNT, para a coleta de fevereiro, na praia da Barra Seca. O menor valor encontrado foi no Costão do Cedro, no mês de janeiro, quando atingiu o valor de 0,30 UNT, conforme mostrado na Tabela 3.

Os valores encontrados para a região em estudo são baixos quando comparados aos obtidos em monitoramento efetuado pela Companhia Energética de São Paulo - CESP (2000a, 2000b), onde os valores mínimos estavam por volta de 18 UNT e máximos de 26 UNT, em água doce, tendo como padrão de referência, valores inferiores a 100 UNT.

A alta turbidez da água reduz a fotossíntese das algas. Esse desenvolvimento reduzido de plantas pode, por sua vez, comprometer a ictiofauna, e de certa forma influenciar a alimentação dos bivalves e outras espécies de pescado, o que certamente não ocorreu nos pontos estudados (CESP, 2000a, 2000b).

Segundo Paoletti (1978) quanto menor a turbidez da água maior a capacidade de concentração dos moluscos. A turbidez é influenciada pelas partículas em suspensão, como as microalgas, a baixa concentração dessas microalgas na água, além de resultar numa baixa turbidez, aumenta a capacidade de filtração de bivalves (Solic et al., 1999).

Nos pontos de cultivo da Barra Seca e Costão do Cedro, houve um ligeiro aumento na turbidez no decorrer dos meses analisados, já, na Almada, houve picos no mês de novembro e março com diminuição nos meses de dezembro, janeiro e fevereiro, como mostra a Tabela 3.

Nos meses de dezembro e março não houve diferença ao nível de significância de 5\%, nas amostras; já nos outros meses alguns valores médios apresentaram diferença significativa. 
Tabela 3. Turbidez da água dos pontos de cultivo nos referidos meses de coleta (UNT).

\begin{tabular}{lccc}
\hline \multicolumn{1}{c}{ Meses } & $\begin{array}{c}\text { Praia da } \\
\text { Almada }\end{array}$ & $\begin{array}{c}\text { Praia da } \\
\text { B. Seca }\end{array}$ & $\begin{array}{c}\text { Costão do } \\
\text { Cedro }\end{array}$ \\
\hline Novembro & $1,00 \mathrm{~A} \mathrm{a}$ & $0,80 \mathrm{~A} \mathrm{ab}$ & $0,35 \mathrm{~B} \mathrm{~b}$ \\
Dezembro & $0,40 \mathrm{~A} \mathrm{~b}$ & $0,70 \mathrm{~A} \mathrm{~b}$ & $0,50 \mathrm{~A} \mathrm{ab}$ \\
Janeiro & $0,50 \mathrm{~B} \mathrm{~b}$ & $0,95 \mathrm{~A} \mathrm{ab}$ & $0,30 \mathrm{~B} \mathrm{~b}$ \\
Fevereiro & $0,35 \mathrm{~B} \mathrm{~b}$ & $1,15 \mathrm{~A} \mathrm{a}$ & $0,45 \mathrm{~B} \mathrm{ab}$ \\
Março & $0,75 \mathrm{~A} \mathrm{ab}$ & $1,00 \mathrm{~A} \mathrm{ab}$ & $0,85 \mathrm{~A} \mathrm{a}$ \\
\hline
\end{tabular}

Nota: Valor de F (Int. Praia X Meses) = 5,11

Coeficiente de variação $=20,93 \%$

Médias seguidas da mesma letra (maiúscula nas linhas e minúsculas nas colunas) não diferem entre si ao nível de 5\% de probabilidade

Valores médios de duplicatas

\subsubsection{Temperatura ambiente e da água}

As coletas foram realizadas durante as estações da primavera, verão e outono.

A temperatura ambiente variou de $24^{0} \mathrm{C}$ a $34^{0} \mathrm{C}$, neste período, sendo a menor temperatura observada a do mês de março, no Costão do Cedro e a maior, a de dezembro, na Almada.

As temperaturas mínima e máxima para a cidade de Ubatuba, nos respectivos meses, em que foram efetuadas estas análises são as seguintes: para novembro, $18^{0}$ e $26,1^{\circ} \mathrm{C}$; para dezembro, $19,6^{0}$ e $28,4^{0} \mathrm{C}$; para janeiro, $20,5^{0}$ a $29,7^{0} \mathrm{C}$; para fevereiro, $20,8^{0}$ e $30,3^{0} \mathrm{C}$ e março, $20,3^{0}$ e $29,4^{0} \mathrm{C}$ (Brasil, 1992). Comparando esses 
dados com os da pesquisa em questão, podemos afirmar que $80 \%$ dos valores obtidos foram superiores às médias registradas como esperadas para esta região.

Quanto aos meses nos quais foram efetuadas as medições, novembro e março, os três pontos de cultivo analisados diferiram, estatisticamente, entre si; no mês de dezembro e janeiro, o ponto de cultivo da Almada, diferiu dos demais pontos estudados, e no mês de fevereiro, o cultivo do Costão diferiu estatisticamente dos demais.

Quanto aos pontos de cultivo estudados, na Almada, os meses de novembro, fevereiro e março não diferiram, significativamente, entre si ao nível de 5\%; os meses de janeiro, fevereiro e março também não, como mostra a Tabela 4.

Tabela 4. Temperatura ambiente $\left({ }^{0} \mathrm{C}\right)$ registrada nos pontos de coleta.

\begin{tabular}{lccc}
\hline \multicolumn{1}{c}{ Meses } & Praia da & Praia da & Costão do \\
& Almada & B. Seca & Cedro \\
\hline Novembro & $32,19 \mathrm{~A} \mathrm{~b}$ & $26,95 \mathrm{~B} \mathrm{~d}$ & $25,34 \mathrm{C} \mathrm{c}$ \\
Dezembro & $34 \mathrm{~A} \mathrm{a}$ & $30 \mathrm{~B} \mathrm{c}$ & $30 \mathrm{~B} \mathrm{~b}$ \\
Janeiro & $31 \mathrm{~B} \mathrm{c}$ & $32,09 \mathrm{~A} \mathrm{a}$ & $31,6 \mathrm{AB}$ a \\
Fevereiro & $31,5 \mathrm{~B} \mathrm{bc}$ & $31,2 \mathrm{~B} \mathrm{~b}$ & $32,19 \mathrm{~A} \mathrm{a}$ \\
Março & $31,5 \mathrm{~A} \mathrm{bc}$ & $26,7 \mathrm{~B} \mathrm{~d}$ & $24 \mathrm{C} \mathrm{d}$ \\
\hline
\end{tabular}

Nota: Valor de F (Int. Praia X Meses) = 8,53

Coeficiente de variação $=0,86 \%$

Médias seguidas da mesma letra (maiúscula nas linhas e minúsculas nas colunas) não diferem entre si ao nível de $5 \%$ de probabilidade

Valores médios realizados em duplicata 
A temperatura ambiente está diretamente ligada à temperatura da água, e esta influencia a fisiologia dos bivalves, constituindo-se no principal fator ambiental de influência na taxa de filtração dos mesmos (Solic et al., 1999).

Os valores para a temperatura da água encontrados nesta pesquisa apresentaram amplitude de variação mais reduzida, de $25^{\circ} \mathrm{C}$ a $30^{\circ} \mathrm{C}$, durante o período de coleta, sendo a menor temperatura, a de dezembro na Almada e Barra Seca e, a maior, a do mês de fevereiro na Barra Seca, como mostra a Tabela 5.

Tabela 5. Temperatura da água de cultivo $\left({ }^{0} \mathrm{C}\right)$ nos pontos de coleta.

\begin{tabular}{lccc}
\hline \multicolumn{1}{c}{ Meses } & Almada & Praias & \\
\hline Novembro & 27,2 A c & 26,4 B c & C. Cedro \\
Dezembro & $25 \mathrm{~B} \mathrm{~d}$ & $25 \mathrm{~B} \mathrm{~d}$ & $28 \mathrm{~A} \mathrm{~b}$ \\
Janeiro & $29,6 \mathrm{~A} \mathrm{a}$ & $30 \mathrm{~A} \mathrm{a}$ & $30 \mathrm{~A} \mathrm{a}$ \\
Fevereiro & $28,5 \mathrm{~B} \mathrm{~b}$ & $29,79 \mathrm{~A} \mathrm{a}$ & $29,5 \mathrm{~A} \mathrm{a}$ \\
Março & $26,79 \mathrm{~B} \mathrm{c}$ & $27,79 \mathrm{~A} \mathrm{~b}$ & $25,9 \mathrm{C} \mathrm{c}$ \\
\hline
\end{tabular}

Nota: Valor de F (Int. Praia X Meses) = 52,76

Coeficiente de variação $=0,758 \%$

Médias seguidas da mesma letra (maiúscula nas linhas e minúsculas nas colunas) não diferem entre si ao nível de 5\% de probabilidade

Valore médios realizados em duplicata

A temperatura da água tem menor variação do que a ambiente ou do solo, sendo que a água tem a capacidade de absorver calor sem sofrer grandes alterações quanto a sua temperatura, pois o elevado calor específico da água atua como um importante tampão, impedindo mudanças bruscas de temperatura do meio aquático, por 
isso é que os animais aquáticos, ao contrário dos terrestres, não têm problemas de drásticas adaptações a amplas flutuações de temperatura (Tommasi, 1979), concordando com valores encontrados nesta pesquisa.

Cerca de $86,7 \%$ das amostras de água do mar apresentaram temperatura inferior à temperatura ambiente.

A temperatura ótima de filtração para mexilhões do Mar Mediterrâneo está entre $15^{0}$ e $25^{0} \mathrm{C}$. Para mexilhões do Mar Báltico a temperatura ótima de filtração está em torno de $17^{0} \mathrm{C}$; temperaturas acima de $20^{\circ} \mathrm{C}$ para mexilhões do mar Báltico e $25^{0} \mathrm{C}$ para mexilhões do Mediterrâneo, resultam em praticamente paralização total da filtração (Solic et al., 1999).

Quanto a temperatura da água nos meses analisados, levando em consideração os meses, em novembro e março todos os pontos de cultivo diferiram estatisticamente entre si; já em janeiro ocorreu o contrário, pois os pontos de cultivo não diferiram entre si; em dezembro, o único ponto que se diferenciou, estatisticamente, dos demais foi o do Costão do Cedro e, em fevereiro, o da Almada.

\subsubsection{Análises microbiológicas}

\subsubsection{Coliformes totais e fecais}

A legislação brasileira não contempla o grupo dos coliformes totais, mas se submetêssemos os valores médios encontrados neste estudo à legislação internacional, quanto às áreas de crescimento de bivalves, que classificam como aprovadas aquelas com NMP de Coliformes totais, águas com valores menores que $70 \mathrm{NMP} / 100 \mathrm{~mL}$ teríamos 93,3\% das áreas pesquisadas aprovadas para cultivo. A praia da Barra Seca em março, teria sua área para aquele mês classificada como restrita, pois seus valores estão entre 70 - 700NMP/100mL, necessitando, portanto, a prática de depuração para os bivalves previamente ao consumo (Houser, 1965; Programa...1989). 
Quanto ao índice de coliformes totais, estes ficaram entre os valores médios de 3,4 a 3,6x10 ${ }^{2} \mathrm{NMP} / 100 \mathrm{~mL}$, como mostra a Tabela 6, sendo que a maior contagem foi encontrada no cultivo da Barra Seca, no mês de março. Também, neste mesmo cultivo, no referido mês, encontrou-se o maior valor médio de coliformes fecais deste estudo, cerca de 5,7x10 $10^{1} \mathrm{NMP} / 100 \mathrm{~mL}$, correspondendo a 6,7\% das amostras analisadas como mostra a Tabela 7. Segundo o Relatório da CETESB (2002), esta mesma praia apresentou contagem (média de 2 amostras) igual a $1,7 \times 10^{4} \mathrm{NMP}$ de coliformes fecais/100 mL de água. Assim, é possível concluir que a contagem diminuiu cerca de 3 casas logarítimicas.

Tabela 6. Coliformes totais em NMP/100 mL na água de cultivo (médias de triplicatas).

\begin{tabular}{cccc}
\hline Meses & Almada & Barra Seca & Costão do Cedro \\
\hline Novembro & 3,4 & $<3,0$ & $<3,0$ \\
Dezembro & $<3,0$ & $<3,0$ & $<3,0$ \\
Janeiro & 5,4 & 3,4 & 5,0 \\
Fevereiro & $<3,0$ & 3,4 & 7,3 \\
Março & 9,8 & $3,6 \times 10^{2}$ & 6,6 \\
\hline
\end{tabular}

Tabela 7. Coliformes fecais em NMP/100 mL na água de cultivo (médias de triplicatas).

\begin{tabular}{cccc}
\hline Meses & Almada & Barra Seca & Costão do Cedro \\
\hline Novembro & $<3,0$ & $<3,0$ & $<3,0$ \\
Dezembro & $<3,0$ & $<3,0$ & $<3,0$ \\
Janeiro & $<3,0$ & 3,1 & $<3,0$ \\
Fevereiro & $<3,0$ & 3,1 & 3,4 \\
Março & 3,4 & $5,7 \times 10^{1}$ & 3,1 \\
\hline
\end{tabular}


Nesta pesquisa, correlacionou-se a incidência de Coliformes Totais com alguns dos microrganismos estudados, como mostra a Tabela 8.

Tabela 8. Coliformes totais na água versus demais microrganismos.

\begin{tabular}{lccc}
\hline \multicolumn{1}{c}{ Microrganismos } & \multicolumn{3}{c}{ Correlação (\%) } \\
& Almada & Barra Seca & Costão do Cedro \\
\hline Sulf. Redutoras NMP/mL & -15 & 69 & 30 \\
Coliformes fecais NMP/mL & 6 & 99 & 87 \\
\hline
\end{tabular}

Para Coliformes totais, encontrou-se correlação positiva muito alta com os Coliformes fecais, nos pontos da Barra Seca e Costão do Cedro, e baixa na Almada. Já para Sulfito Redutores houveram correlações negativas baixas para o ponto da Almada, positiva alta para o cultivo da Barra Seca e moderada para o cultivo do Costão do Cedro, como mostra a Tabela 8.

Evison (1988), tentando verificar o efeito da temperatura na mortalidade de coliformes, submeteu amostras de água do mar a diferentes temperaturas: 2, 5, 10, 20, $25^{\circ} \mathrm{C}$. Os resultados mostraram que a mortalidade foi maior nas maiores temperaturas; nesta pesquisa observou-se que não ocorreu mortalidade nas maiores temperaturas.

Os resultados encontrados para as águas de cultivo, apresentaram-se satisfatórios da ordem de 93,3\%, condizentes com a legislação em vigor para águas Classe 5 (águas salinas para o uso de criação natural e/ou intensiva de espécies destinadas à alimentação humana e que serão ingeridas in natura). No entanto, a presença de bactérias coliformes fecais em 6,7\% das amostras, acima do limite estipulado pela Resolução do CONAMA n 20, de 18 de junho de 1986, Artigo 8ºm reforçar a necessidade de um programa de monitoramento da qualidade das águas junto às regiões de cultivo, garantindo a segurança do consumidor, principalmente quando levamos em conta que o consumidor em potencial de mexilhões, é o turista e o afluxo 
destes é maior no verão, o que também eleva a carga de efluentes despejados nas águas nesta época, acarretando problemas com contaminação.

Correlacionou-se a contagem microbiana com o índice pluviométrico, conforme apresentado na Tabela 9. Verificou-se alta correlação para coliformes totais para as praias da Almada e Barra Seca e alta para coliformes fecais na Barra Seca, concordando com Cetesb... (2003); Salati Filho (2001) e Lizárraga-partida \& Cárdenas (1996). Estes autores afirmaram que as chuvas interferem no índice de qualidade microbiológica da água, pois estas têm a capacidade de arrastar esgotos e resíduos sólidos para os cursos d’água que, por sua vez, afluem para o mar. Ainda para coliformes totais, obteve-se correlação positiva baixa no cultivo do Costão, enquanto que para coliformes fecais houve correlação negativa baixa para os cultivos da Almada e Costão do Cedro.

Tabela 9. Microrganismos analisados na água versus índice pluviométrico.

\begin{tabular}{lccc}
\hline \multicolumn{1}{c}{ Microrganismos } & \multicolumn{3}{c}{ Correlação (\%) } \\
& Almada & Barra Seca & Costão do Cedro \\
\hline Heterotróficas UFC/mL & 72 & 84 & -41 \\
Sulf. Redutoras NMP/mL & 51 & 95 & 53 \\
Coliformes totais NMP/mL & 76 & 82 & 17 \\
Coliformes fecais NMP/mL & -8 & 82 & -8 \\
\hline
\end{tabular}

Correlacionou-se a contagem microbiana com a tábua das marés e todos os resultados encontrados mostraram correlações baixas; 64\% das correlações estabelecidas foram negativas, (conforme Tabela 10), pois nas marés vazantes a contagem microbiana aumentou (mesmo com baixa correlação), concordando com dados descritos pela Cetesb (2003) e Salati Filho (2001). As marés influem de forma incisiva na presença de esgotos nas águas das praias, pois durante as marés cheias, as águas da praia, agem no sentido de 
barrar cursos d’água eventualmente contaminados; já nas marés vazantes, ocorre fenômeno inverso, havendo uma drenagem nas águas desses córregos para o mar, causando a presença, na praia, de maior quantidade de esgotos.

Tabela 10. Microrganismos analisados na água versus tábua de marés.

\begin{tabular}{lccc}
\hline \multicolumn{1}{c}{ Microrganismos } & \multicolumn{3}{c}{ Correlação (\%) } \\
& Almada & Barra Seca & Costão do Cedro \\
\hline Heterotróficas UFC/mL & $-0,2$ & $-0,5$ & 0,8 \\
Sulf. Redutoras NMP/mL & $-0,04$ & $-0,6$ & 0,43 \\
Coliformes totais NMP/mL & $-0,18$ & $-0,52$ & 0,81 \\
Coliformes fecais NMP/mL & 0,5 & $-0,52$ & 0,83 \\
\hline
\end{tabular}

Correlacionou-se também a contagem microbiana com os dados de insolação diária. Na região de estudo obteve-se alta correlação negativa para Heterotróficos nos pontos da Almada e Barra Seca; Sulfito Redutores na Barra Seca e Costão do Cedro; coliformes totais na Almada e Barra Seca; coliformes fecais na Barra Seca; totalizando 100\% de correlações negativas, conforme mostra a Tabela 11.

Tabela 11. Microrganismos analisados na água versus insolação diárias (h).

\begin{tabular}{lccc}
\hline \multicolumn{1}{c}{ Microrganismos } & \multicolumn{3}{c}{ Correlação (\%) } \\
& Almada & Barra Seca & Costão do Cedro \\
\hline Heterotróficas UFC/mL & -71 & -80 & 14 \\
Sulf. Redutoras NMP/mL & -46 & -87 & -72 \\
Coliformes totais NMP/mL & -72 & -77 & -46 \\
Coliformes fecais NMP/mL & -18 & -77 & -18 \\
\hline
\end{tabular}


Vários estudos afirmam que a irradiação solar é um fator fundamental na mortalidade dos coliformes na água do mar, sendo a taxa de mortalidade 70 a 80 vezes maior em presença de raios solares do que em ausência de luz (Bonnefont et al. 1990; Chamberlin \& Mitchel, 1978; Fujioka et al., 1981; Sarikaya \& Saatci, 1995). Portanto, esperava-se correlação positiva, o que não ocorreu nos dados encontrados nesta pesquisa. Outro fator que influencia a ação dos raios solares é a turbidez da água. Em águas pouco turvas, como é o caso das amostras aqui estudadas, espera-se correlação mais alta, pois quanto maior o grau de insolação, maior a mortalidade de coliformes (Anderson et al., 1983).

Paula (1978) constatou picos coliformes fecais no outono, concordando com os dados encontrados nesta pesquisa, quando maior contagem média de coliformes fecais se deu em março.

Os coliformes têm pouca tolerância à salinidade das águas do mar, portanto sua detecção nesse ambiente denota uma descarga recente e constante de matéria fecal, o que provavelmente vem ocorrendo em algumas dessas áreas (Hagler \& Hagler, 1988; Gallacher \& Spino, 1968). Assim, a população de coliformes fecais encontrada na água coletada na Praia da Barra Seca, no mês de março, indica a contaminação por esgoto, o que pode colocar em risco a saúde do consumidor.

As contagens para as bactérias coliformes totais encontradas nesta pesquisa, apresentaram-se muito próximas das bactérias coliformes fecais, não apresentando grandes diferenças entre pontos de coleta, nem entre os meses de coletas, excetuando-se a de março, quando as amostras coletadas, na praia Barra Seca, apresentaram contagens superiores às dos demais pontos de coleta, como já referido anteriormente. Portanto, podemos concluir, que grande parte da contagem de bactérias coliformes totais encontradas neste estudo, em quase todos os meses, é constituída de coliformes fecais. 


\subsubsection{Enterococcus sp}

Os Enterococcus sp estiveram presentes em apenas 6,7\% das amostras de água do mar durante todo o estudo, sendo que o maior valor médio encontrado foi de 4,4 NMP/100 mL na praia da Barra Seca, no mês de março, conforme mostra a Tabela 12 .

Tabela 12. Enterococcus sp em NMP/100 mL na água de cultivo (médias de triplicatas)

\begin{tabular}{cccc}
\hline Meses & Almada & Barra Seca & Costão do Cedro \\
\hline Novembro & $<3,0$ & $<3,0$ & $<3,0$ \\
Dezembro & $<3,0$ & $<3,0$ & $<3,0$ \\
Janeiro & $<3,0$ & $<3,0$ & $<3,0$ \\
Fevereiro & $<3,0$ & $<3,0$ & $<3,0$ \\
Março & $<3,0$ & 4,4 & $<3,0$ \\
\hline
\end{tabular}

Segundo a Cetesb...(2003), os enterococos são os melhores indicadores porque sobrevivem melhor nas condições de águas marinhas, quando comparados a coliformes e E. coli, notificando a inserção da análise de enterococos nos programas de monitoramento de balneabilidade das praias, o que não pudemos constatar nesta pesquisa, pois a incidência desse microrganismo foi muito baixa.

Os enterococos podem persistir por longo tempo em águas de irrigação, com alto teor eletrolítico, porém não se multiplicam nas águas poluídas. Adicionalmente, a identificação deste grupo pode dar uma indicação da origem da contaminação fecal (humana ou animal). A sua maior resistência aos diversos processos de tratamento de esgoto, em comparação com os coliformes fecais, permite uma correlação direta com a sobrevivência sanitária, pois seu habitat não é restrito ao trato 
intestinal (Silva et al., 2000). Os os maiores valores de contagem para Enterococcus sp, coincidiram com as maiores contagens para coliformes fecais, demonstrando que estes microrganismos estão ligados a maior poluição.

\subsubsection{Clostrídios sulfito redutores}

Nesta pesquisa, as amostras oscilaram entre valores 3,2 NMP/100mL a valores de $1,5 \times 10^{1} \mathrm{NMP} / 100 \mathrm{~mL}$, sendo que em 33\% das amostras, o método de análise utilizado permitiu detectar o microrganismo (<3,0 NMP/100 mL), como mostra a Tabela 13.

Tabela 13. Clostrídios Sulfito Redutores em NMP/100 mL na água de cultivo (médias de triplicatas).

\begin{tabular}{cccc}
\hline Meses & Almada & Barra Seca & Costão do Cedro \\
\hline Novembro & $<3,0$ & $<3,0$ & $<3,0$ \\
Dezembro & 26,3 & 13 & 4,9 \\
Janeiro & 3,2 & 3,4 & 4,4 \\
Fevereiro & 4,4 & $<3,0$ & $<3,0$ \\
Março & 9,2 & $1,5 \times 10^{1}$ & 3,2 \\
\hline
\end{tabular}

Correlacionou-se também a contagem de Clostrídios Sulfito Redutores com o índice pluviométrico. Todas as correlações obtidas foram positivas, obteve-se correlação muito alta para a praia da Barra Seca, e moderada para os demais pontos, como mostra a Tabela 9. 
Os resultados referentes às análises de coliformes, somados às de Clostrídios Sulfito-Redutores, indicam contaminação contínua da água do mar, resultando em um problema permanente, portanto, medidas preventivas devem ser tomadas quanto a busca permanente pela melhora da qualidade da água, pois a tendência é o aumento da quantidade de efluentes lançados ao mar.

\subsubsection{Salmonella sp}

No presente estudo não foi detectada a presença da Salmonella sp em nenhum dos locais e meses amostrados, conforme se observa na Tabela 14, concordando com dados encontrados no trabalho de Sato et al. (1992) e Rodrigues (1998) ambos realizados em Ubatuba. A Salmonella sp apresenta-se em uma proporção variável nas águas denominadas como poluídas, sendo que os relatos para esses microrganismos têm sido associados à falta de saneamento (Huss et al., 2000; Silva et al., 2000; WHO, 1999).

Tabela 14. Salmonella sp em 25 mL na água de cultivo (médias de triplicatas).

\begin{tabular}{cccc}
\hline Meses & Almada & Barra Seca & Costão do Cedro \\
\hline Novembro & Ausência & Ausência & Ausência \\
Dezembro & Ausência & Ausência & Ausência \\
Janeiro & Ausência & Ausência & Ausência \\
Fevereiro & Ausência & Ausência & Ausência \\
Março & Ausência & Ausência & Ausência \\
\hline
\end{tabular}


Andrews et al. (1975) e Martinez-Manzares, (1992) não obtiveram relação consistente entre os níveis de coliformes totais na água e a presença de Salmonella, concordando com os valores encontrados neste estudo, enquanto Martins (1983a), obtive boa correlação.

Geldreick (1967) e Geldreick \& Van Donsel (1970), devido à semelhante sobrevivência de coliformes fecais e outros patógenos em águas estuarinas poluídas, correlacionaram a densidade de coliformes fecais com a ocorrência de Salmonella, sendo demonstrado que na presença de $<2,0 \times 10^{2} \mathrm{CF} / 100 \mathrm{~mL}$, a ocorrência de Salmonella seria de 6,5 a 31\%. A densidade de $<1,0 \times 10^{3}$ CF/100 mL determinaria uma freqüência duplicada daqueles patógenos. Neste estudo, o valor médio máximo encontrado para coliformes fecais foi de 5,7x10 NMP/100 mL, não sendo encontrada presença de Salmonella em nenhuma das amostras analisadas, não havendo portanto condições de estabelecimento de nenhum tipo de correlação.

Em trabalho realizado em Dauphin Island, no Alabama, Andrews et al. (1975), afirmaram que em áreas de cultivo de moluscos que estavam de acordo com a legislação vigente local (<70 CT/100 mL e <14 CF/100 mL), não ocorreu nenhum isolamento de salmonela. Comparando esses dados aos obtidos nesta pesquisa, somente no mês de março, no cultivo da Barra Seca é que os valores foram excedidos para coliformes fecais, mas ao contrário da afirmação acima não foi efetuado isolamento de nenhuma espécie de Salmonela.

Sayler et al. (1976) afirmam que havendo uma maior incidência de coliformes fecais, haverá maior isolamento de Salmonella spp, diferentemente do que ocorreu na presente pesquisa.

Devido à metodologia empregada para esta análise, na qual utiliza-se uma alíquota de apenas $25 \mathrm{~mL}$ de água, a probabilidade de se detectar um resultado positivo é menor (Nóbrega, 1982); a presença de salmonelas em água não pode, muitas vezes, ser comprovada devido à inadequação da metodologia empregada e, usualmente, pelo fato das salmonelas encontrarem-se em pequeno número.

Outro fato importante constatado por alguns autores é que a salmonela pode ser isolada com mais sucesso em águas com certa profundidade quando 
comparadas às águas de superfície, cuja proporção pode ser 100 a 1000 vezes maior (Nóbrega, 1982; Sayler et al., 1976). Este fato é explicado pelo curto tempo de sobrevida das salmonelas em água do mar, e relacionado a vários fatores como, diluição, falta de nutrientes, correntes marinhas, sedimentação, temperatura, luz e competição com outros microorganismos (Germano et al., 1993; Sayler \& Nelson, 1976; Nóbrega, 1982).

Coetzee (1963), verificou a viabilidade de sobrevivência da $S$. thyphi e $S$. paratyphy em águas marinhas, constatando mortalidade de 94\% da primeira espécie estudada em 24 horas, sendo a segunda espécie mais resistente (120 h), concordando com os demais autores já discutidos acima, quanto à curta sobrevida da Salmonella em água do mar.

Outros autores concluíram que organismos patogênicos entéricos podem ser isolados das águas, nem sempre refletidos pelas densidades dos organismos indicadores, sugerindo que se suplemente a contagem de coliformes com a densidade de Salmonella (Dutka, 1973; Dutka \& Bell,1973).

\subsubsection{Staphylococcus aureus}

Não se detectou a presença de $S$. aureus nas áreas estudadas, conforme mostra a Tabela 15. Rodrigues (1998) estudou a incidência de S. aureus em outras áreas de cultivo de bivalves em Ubatuba, e constatou a ausência desses microrganismos nas mesmas. 
Tabela 15. Staphylococcus aureus UFC/mL na água de cultivo (médias de triplicatas).

\begin{tabular}{cccc}
\hline Meses & Almada & Barra Seca & Costão do Cedro \\
\hline Novembro & $<1,0 \times 10^{1}$ & $<1,0 \times 10^{1}$ & $<1,0 \times 10^{1}$ \\
Dezembro & $<1,0 \times 10^{1}$ & $<1,0 \times 10^{1}$ & $<1,0 \times 10^{1}$ \\
Janeiro & $<1,0 \times 10^{1}$ & $<1,0 \times 10^{1}$ & $<1,0 \times 10^{1}$ \\
Fevereiro & $<1,0 \times 10^{1}$ & $<1,0 \times 10^{1}$ & $<1,0 \times 10^{1}$ \\
Março & $<1,0 \times 10^{1}$ & $<1,0 \times 10^{1}$ & $<1,0 \times 10^{1+}$ \\
\hline
\end{tabular}

\subsubsection{Bacillus cereus}

O B. cereus foi detectado em apenas $6,7 \%$ das amostras, no cultivo da Almada no mês de março, como mostra a Tabela 16.

Tabela 16. Bacillus cereus UFC/mL na água de cultivo (médias de triplicatas).

\begin{tabular}{cccc}
\hline Meses & Almada & Barra Seca & Costão do Cedro \\
\hline Novembro & $<1,0 \times 10^{1}$ & $<1,0 \times 10^{1}$ & $<1,0 \times 10^{1}$ \\
Dezembro & $<1,0 \times 10^{1}$ & $<1,0 \times 10^{1}$ & $<1,0 \times 10^{1}$ \\
Janeiro & $<1,0 \times 10^{1}$ & $<1,0 \times 10^{1}$ & $<1,0 \times 10^{1}$ \\
Fevereiro & $<1,0 \times 10^{1}$ & $<1,0 \times 10^{1}$ & $<1,0 \times 10^{1}$ \\
Março & $1,3 \times 10^{1}$ & $<1,0 \times 10^{1}$ & $<1,0 \times 10^{1}$ \\
\hline
\end{tabular}


O B. cereus é uma bactéria largamente distribuída na natureza e em alimentos, estando comumente associada a alimentos ricos em carboidrato e raramente associada a produtos marinhos. No entanto, quando se trata de mexilhão este apresenta carboidrato em sua constituição e, conseqüentemente devido ao seu hábito filtrador e bioacumulador, a presença destes no ambiente pode ser um problema em potencial, embora a incidência na água do mar do B. cereus nesta pesquisa tenha sido muito reduzida.

\subsubsection{Microrganismos aeróbios mesófilos (Heterotróficos)}

Os valores médios encontrados para bactérias heterotróficas, variaram de $1,3 \times 10^{1} \mathrm{UFC} / \mathrm{mL}$ a $3,0 \times 10^{2} \mathrm{UFC} / \mathrm{mL}$, conforme mostra a Tabela 17 , sendo que em $60 \%$ das amostras foram detectados heterotróficos.

Tabela 17. Heterotróficos UFC/mL na água de cultivo (médias de triplicatas).

\begin{tabular}{cccc}
\hline Meses & Almada & Barra Seca & Costão do Cedro \\
\hline Novembro & $1,3 \times 10^{1}$ & $<1,0 \times 10^{1}$ & $<1,0 \times 10^{1}$ \\
Dezembro & $<1,0 \times 10^{1}$ & $2,9 \times 10^{1}$ & $<1,0 \times 10^{1}$ \\
Janeiro & $1,3 \times 10^{1}$ & $<1,0 \times 10^{1}$ & $<1,0 \times 10^{1}$ \\
Fevereiro & $1,6 \times 10^{1}$ & $1,6 \times 10^{1}$ & $1,7 \times 10^{2}$ \\
Março & $4,3 \times 10^{1}$ & $3,0 \times 10^{2}$ & $1,6 \times 10^{1}$ \\
\hline
\end{tabular}


Lizzárraga-Partida \& Cárdenas (1996), constataram que alguns fatores ambientais como chuvas e marés influenciam na contagem de heterotróficos, concordando com dados encontrados nesse trabalho quando correlacionou-se o índice pluviométrico com a contagem de Heterotróficos como mostr a Tabela 9.

A contagem padrão de bactérias aeróbias heterotróficas mesófilas é considerada a técnica que melhor estima a densidade de bactérias contaminantes em águas não potáveis. A importância da avaliação do grau de poluição dessas águas utilizando a contagem padrão de bactérias, está relacionada à determinação e delimitação da fonte poluidora, além de reforçar os padrões de qualidade da água e de traçar a sobrevivência de microrganismos (APHA, 1992). Segundo Silva et al. (2000), esta contagem objetiva estimar o número de bactérias heterotróficas na água, particularmente como uma ferramenta para acompanhar possíveis variações, da forma como ocorreu nesta pesquisa, cuja maior contagem foi detectada no mês de março na praia da Barra Seca, coincidindo com contagens médias máximas para coliformes totais, fecais e Enterococcus sp no mesmo mês e praia, correlacionando todos esses microrganismos com conseqüente maior quantidade de efluentes orgânicos (esgoto).

Neste caso, a água de cultivo pode agir como fonte de contaminação para os mexilhões.

\subsubsection{Bolores e leveduras}

Não foram detectados bolores e leveduras na água do mar nos pontos de cultivo estudados, durante o meses de coleta, como mostra a Tabela 18, o que pode ser explicado pelo fator limitante da distribuição de fungos em ambientes marinhos, pois todos eles requerem oxigênio para respiração com exceção de algumas leveduras. Isto significa que eles só ocorrem na água e superfície de sedimentos, por eles degradarem matéria orgânica, portanto, o ambiente tem que possuir matéria orgânica disponível para esses microrganismos (Wood, 1975). 
Tabela 18. Bolores e leveduras UFC/mL na água de cultivo (médias de triplicatas).

\begin{tabular}{cccc}
\hline Meses & Almada & Barra Seca & Costão do Cedro \\
\hline Novembro & $<1,0 \times 10^{1}$ & $<1,0 \times 10^{1}$ & $<1,0 \times 10^{1}$ \\
Dezembro & $<1,0 \times 10^{1}$ & $<1,0 \times 10^{1}$ & $<1,0 \times 10^{1}$ \\
Janeiro & $<1,0 \times 10^{1}$ & $<1,0 \times 10^{1}$ & $<1,0 \times 10^{1}$ \\
Fevereiro & $<1,0 \times 10^{1}$ & $<1,0 \times 10^{1}$ & $<1,0 \times 10^{1}$ \\
Março & $<1,0 \times 10^{1}$ & $<1,0 \times 10^{1}$ & $<1,0 \times 10^{1}$ \\
\hline
\end{tabular}

No Brasil, os estudos sobre a incidência de leveduras em ambientes marinhos são muito raras (Paula 1978). As leveduras de habitats marinhos possuem correspondentes terrestres, e existem evidências consideráveis de que as mesmas são muito mais abundantes, devido ao carreamento de tais microrganismos, a partir do solo, pelas águas dos rios e canais e, também, pela poluição com resíduos domésticos e industriais, os quais fornecem nutrientes adicionais àqueles já existentes (Ahearn \& Meyers, 1972; Cooke et al., 1960; Fell \& Van Uden, 1963; Meyer et al. 1967). No caso do presente estudo, não se pode conciliar aumento da poluição com o aumento da contagem desses microrganismos, pois estas não variaram.

Segundo dados de Paula (1978) há correlação positiva entre a quantidade de Coliformes Fecais com a incidência de leveduras nas praias de São Vicente, já nas praias de Bertioga, ocorreu o contrário, onde obteve-se menores índices bacterianos, ocorreu também menor isolamento de fungos. Segundo o mesmo autor, levando-se em consideração estudos em outras regiões e padronização da metodologia de trabalho, o gênero Cândida poderá ser empregado como novo indicador de poluição em águas de estuários marinhos. 


\subsection{Mexilhões}

\subsubsection{Análises físico-químicas}

\subsubsection{1 pH}

Os valores de $\mathrm{pH}$ variaram de 5,66 a 6,81, conforme mostram as Tabelas 19 e 20. O Regulamento da Inspeção Industrial e Sanitária de Produtos de Origem Animal RIISPOA (Brasil, 2001), estabelece limites máximos para $\mathrm{pH}$, de 6,5, na parte interna das espécies de pescado fresco, estando 60\% dos valores encontrados nesse estudo, dentro do limite estabelecido Cabe aqui salientar a necessidade de estudos específicos quanto aos limites de $\mathrm{pH}$ para moluscos bivalves, pois estes possuem composição centesimal diversificada quando comparada a de outras espécies de pescado, e certamente, a decomposição e alteração do pH ocorrem de forma diferente.

Levando em consideração os pontos de cultivo, eles não diferiram, significativamente, entre si ao nível de 5 \%, como mostra a Tabela 19. Já levando em consideração o fator mês, o de fevereiro diferenciou-se dos demais ao nível de 5\%, apresentando a média mais alta como mostra a Tabela 20. Os meses de dezembro e janeiro; e os meses de novembro e março não diferiram entre si ao nível de 5\%.

$\mathrm{O}$ pH do alimento é um fator muito importante na conservação dos alimentos, em conseqüência disto, tendo o pescado um pH próximo da neutralidade, este propicia o desenvolvimento tanto de microrganismos deterioradores como de patógenos, portanto, a matéria-prima requer cuidados especiais quanto a sua conservação. 
Tabela 19. pH de mexilhões referentes aos pontos de cultivo.

\begin{tabular}{cccc}
\hline Pontos de Cultivo & Almada & Barra Seca & Costão do Cedro \\
\hline $6,24 \mathrm{a}$ & $6,22 \mathrm{a}$ & $6,30 \mathrm{a}$ \\
\hline
\end{tabular}

Nota: Valor de F para o fator praia $=1,23$

Coeficiente de variação $=1,89 \%$

Médias seguidas da mesma letra não diferem entre si ao nível de $5 \%$ de probabilidade

Valores médias realizados em duplicata

Tabela 20. pH de mexilhões referentes aos meses de coleta.

\begin{tabular}{cccccc}
\hline Pontos de Cultivo & Novembro & Dezembro & Janeiro & Fevereiro & Março \\
\hline & $5,66 \mathrm{c}$ & $6,46 \mathrm{~b}$ & $6,60 \mathrm{~b}$ & $6,81 \mathrm{a}$ & $5,71 \mathrm{c}$ \\
\hline
\end{tabular}

Nota: Valor de F para o fator meses $=119,5$

Coeficiente de variação = 1,89\%

Médias seguidas da mesma letra não diferem entre si ao nível de 5\% de probabilidade

Valores médias realizadas em duplicata

\subsubsection{Biometria das valvas}

Para a variável tamanho, os valores médios ficaram entre 4, $78 \mathrm{~cm}$, no mês de março, na praia da Barra Seca e, 7,81 cm, no mês de fevereiro, na praia da Almada, conforme mostrado na Tabela 21. Marques (1998), relata que, no litoral paulista, os mexilhões costumam ser comercializados a partir dos $5 \mathrm{~cm}$ de comprimento, não sendo 
vantajoso para o produtor esperar os animais atingirem comprimentos maiores para comercializá-los, já que o crescimento, praticamente, se estabiliza após os $6 \mathrm{~cm}$, diferentemente do que ocorre em outros estados como Rio de Janeiro e Santa Catarina.

Tabela 21. Tamanho das valvas em cm dos mexilhões.

\begin{tabular}{lccc}
\hline \multicolumn{1}{c}{ Meses } & $\begin{array}{c}\text { Praia da } \\
\text { Almada }\end{array}$ & $\begin{array}{c}\text { Praia da } \\
\text { B. Seca }\end{array}$ & $\begin{array}{c}\text { Costão do } \\
\text { Cedro }\end{array}$ \\
\hline Novembro & $7,17 \mathrm{~A} \mathrm{~d}$ & $5,73 \mathrm{C} \mathrm{b}$ & $6,42 \mathrm{~B} \mathrm{a}$ \\
Dezembro & $7,44 \mathrm{~A} \mathrm{c}$ & $5,84 \mathrm{~B} \mathrm{~b}$ & $5,88 \mathrm{~B} \mathrm{bc}$ \\
Janeiro & $7,63 \mathrm{~A} \mathrm{ab}$ & $6,29 \mathrm{~B} \mathrm{a}$ & $5,86 \mathrm{C} \mathrm{c}$ \\
Fevereiro & $7,81 \mathrm{~A} \mathrm{a}$ & $5,16 \mathrm{C} \mathrm{c}$ & $6,06 \mathrm{~B} \mathrm{~b}$ \\
Março & $7,50 \mathrm{~A} \mathrm{bc}$ & $4,78 \mathrm{C} \mathrm{d}$ & $6,48 \mathrm{~B} \mathrm{a}$ \\
\hline
\end{tabular}

Nota:Valor de F (Int. Praia X Meses) = 60,24

Coeficiente de variação $=9,5 \%$

Médias seguidas da mesma letra (maiúscula nas linhas e minúsculas nas colunas) não diferem entre si ao nível de 5\% de probabilidade

Valore médios com amostras de 100 valvas

Assumpção (1999), em relatório de estágio realizado no Instituto de Pesca de Ubatuba, cita que nos meses de fevereiro, março, julho e agosto, os mexilhões de cultivo alcançam cerca de $8 \mathrm{~cm}$, concordando parcialmente com dados encontrados nesta pesquisa.

Segundo Solic et al. (1999), há correlação negativa entre o tamanho do bivalve e a taxa de filtração do animal, pois quanto maior o tamanho do bivalve menor a taxa de filtração. 
Nos meses de novembro, janeiro, fevereiro e março todos os pontos variaram, significativamente, ao nível de 5\% quanto ao tamanho, sendo que na praia da Barra Seca, estão os menores valores, e na praia da Almada, os maiores (Tabela 21).

O crescimento e a produtividade dos mexilhões, seja de cultivo ou de bancos naturais, dependem de diversos fatores como a temperatura, a salinidade, a circulação da água, a densidade dos indivíduos, a quantidade e a qualidade de alimento disponível e a baixa incidência de parasitas, competidores e predadores. Neste trabalho, nos organismos com grandes quantidades de cracas, notou-se a incidência de menor crescimento, concordando com afirmações de Henriques (2001).

Segundo Quayle \& Newkirk (1989), o crescimento da concha é altamente dependente da temperatura; quando a temperatura da água é elevada o ano todo, o crescimento da concha ocorre de forma contínua. Os mesmos autores afirmam que em regiões tropicais não há tanta variação de temperatura, concordando com dados deste trabalho que, embora a variação em alguns pontos e meses tenha ocorrido de forma significativa, o intervalo de diferenças entre elas foi pequeno.

\subsubsection{Análises microbiológicas}

\subsubsection{Coliformes totais e fecais}

Os resultados médios de coliformes totais obtidos nesta pesquisa apresentaram uma variação de $2,5 \times 10^{1} \mathrm{NMP} / \mathrm{g}$ a $2,3 \times 10^{3} \mathrm{NMP} / \mathrm{g}$, sendo que a maior contagem também foi encontrada nas amostras da Barra Seca, referente a coleta do mês de janeiro e, a menor, na coleta no Costão do Cedro, no mês de março, como mostra a Tabela 22. Apesar da legislação brasileira não possuir padrão para este tipo de alimento, no que se refere a coliformes totais, tais análises foram realizadas para que se tivesse uma noção da presença desses microrganismos no alimento, assim como da qualidade higiênico-sanitária deste, pois a contagem dos coliformes totais corresponde ao total dos 
microrganismos gram-negativos, da família das Enterobacteriaceae, encontrados em uma amostra.

Tabela 22. Coliformes totais NMP/g em mexilhões coletados nos diferentes pontos de cultivo (médias de duplicatas).

\begin{tabular}{cccc}
\hline Meses & Almada & Barra Seca & Costão do Cedro \\
\hline Novembro & $9,6 \times 10^{2}$ & $2,6 \times 10^{2}$ & $1,6 \times 10^{3}$ \\
Dezembro & $4,3 \times 10^{1}$ & $4,3 \times 10^{2}$ & $4,3 \times 10^{1}$ \\
Janeiro & $1,6 \times 10^{3}$ & $2,3 \times 10^{3}$ & $6,8 \times 10^{2}$ \\
Fevereiro & $6,8 \times 10^{1}$ & $1,4 \times 10^{3}$ & $3,3 \times 10^{1}$ \\
Março & $3,3 \times 10^{2}$ & $1,4 \times 10^{3}$ & $2,5 \times 10^{1}$ \\
\hline
\end{tabular}

Os valores médios de coliformes fecais variaram de 3,2 NMP/g, na praia do

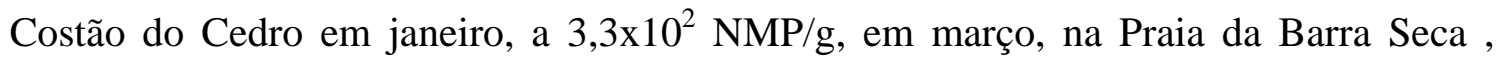
como mostra a Tabela 23, sendo que os maiores valores de coliformes fecais na carne, coincidiram com o período e o local em que a água de cultivo apresentou maior contagem para coliformes fecais. Em se tratando de bivalves in natura, a legislação brasileira não apresenta nenhuma menção, a não ser para produtos processados como bivalves cozidos resfriados/congelados $\left(5,0 \times 10^{1}\right)$, bivalves secos e salgados ou em semi conservas $\left(10^{2}\right)$, e bivalves defumados ou produtos de surimi $\left(10^{2}\right)$ (Brasil, 2001). Em citações de 1998, Anexo I da Portaria n ${ }^{0} 451$ do Ministério da Saúde, Secretaria de Vigilância Sanitária (Brasil, 1998), o limite de tolerância para coliformes fecais em moluscos in natura, refrigerados ou congelados é de no máximo $10^{2}$ coliformes fecais por grama de produto, portanto, de acordo com Brasil (1998), apenas a amostra da Barra Seca, no mês de março, está acima dos limites estabelecidos pela legislação, pois atingiu valores médios de 3,3 x $10^{2} \mathrm{UFC} / \mathrm{g}$. 
Tabela 23. Coliformes fecais NMP/g em mexilhões coletados nos diferentes pontos de cultivo (médias de duplicatas).

\begin{tabular}{cccc}
\hline Microrganismos & Almada & Barra Seca & Costão do Cedro \\
\hline Novembro & $<3,0$ & $3,3 \times 10^{1}$ & 9,1 \\
Dezembro & $2,3 \times 10^{1}$ & 9,1 & 9,1 \\
Janeiro & $1,6 \times 10^{1}$ & $1,6 \times 10^{1}$ & 3,2 \\
Fevereiro & 3,3 & $9,3 \times 10^{1}$ & $1,6 \times 10^{1}$ \\
Março & $1,6 \times 10^{1}$ & $3,3 \times 10^{2}$ & 8,2 \\
\hline
\end{tabular}

Os coliformes fecais são indicadores específicos e apresentam uma elevada correlação positiva com a contaminação fecal por animais de sangue quente. A alimentação por filtração efetuada pelos mexilhões concentra os coliformes presentes no ambiente marinho. A concentração destes no tecido comestível dos moluscos indica o perigo potencial à saúde dos consumidores.

Considerando-se que os moluscos bivalves, como os mexilhões, se comportam como filtradores e, portanto, acumulam microrganismos do meio ambiente, sua segurança como alimento para o homem está diretamente relacionada à qualidade bacteriológica das águas em que se desenvolvem. Segundo estudos realizados por Turick et al. (1988), os mexilhões podem reter e concentrar números de coliformes fecais 15 a 20 vezes maior do que o observado na água à sua volta; Pinheiro Junior (2000), também confirmou essa tendência de concentração, Lizárraga-Partida \& Cárdenas (1996); Mahassneh \& Alsayed (1997); Rodrigues (1998), afirmam que a contagem de coliformes de moluscos é sempre maior do que na água, não havendo, porém, um padrão definido.Os dados obtidos nesta pesquisa são concordantes com os resultados por estes autores citados.

Correlacionou-se a contagem de Coliformes totais e fecais no mexilhão em relação à da água; os coliformes totais apresentaram correlação positiva baixa para os pontos da Almada e Barra Seca, e correlação negativa moderada, para o Costão do 
Cedro; já para os coliformes fecais, os pontos da Barra Seca e do Costão do Cedro apresentaram correlação positiva alta, enquanto na Almada ocorreu correlação positiva baixa, como mostra a Tabela 24.

Tabela 24. Coliformes totais e fecais da água versus do mexilhão.

\begin{tabular}{cccc}
\hline Microrganismos & Correlação (\%) & \\
& Almada & Barra Seca & Costão do Cedro \\
\hline Coliformes totais NMP/mL & 10 & 16 & -56 \\
Coliformes fecais NMP/mL & 24 & 97 & 81 \\
\hline
\end{tabular}

Outro fator que pode explicar o fato de mexilhões apresentarem sempre contagens maiores quando comparadas às perspectivas de proveniência é que os patógenos e indicadores bacterianos podem sobreviver mais tempo em bivalves do que em água do mar, além disso nos bivalves eles podem se reproduzir (Solic et al., 1999), fato que pode causar uma diminuição, ou um tempo de sobrevida mais curto, do patógeno no sistema digestivo do mexilhão devido a lise das células durante a digestão (Legnani et al., 1998).

Cabelli \& Heffernan (1970), medindo a taxa de acumulação de E. coli por bivalves, afirmam que esta não é dependente somente da concentração da mesma na água, mas também da relação do organismo com as partículas e sua digestibilidade

A enumeração de coliformes totais em água é menos representativa como indicação de contaminação fecal que a enumeração de coliformes termotolerantes ou Escherichia coli; no entanto, sua enumeração é muito utilizada em indústrias alimentícias, indicando poluição pré-sanitização, contaminação pós-sanitização ou pósprocesso, evidenciando práticas de higiene e sanitização aquém dos padrões requeridos para o processamento de alimentos (Pádua, 2003). 


\subsubsection{Clostrídios Sultito Redutores e Clostridium perfringens}

A contagem de esporos de Clostrídios Sulfito Redutores variou de 1,0×10 ${ }^{1}$ UFC/g no mês de fevereiro, no Costão de Cedro, a 2,2×10² UFC/g no mês de março na Barra Seca, conforme mostra a Tabela 25, sendo que o principal representante deste grupo de bactérias, é o Clostridium perfringens.

Tabela 25. Clostrídios Sulfito Redutores NMP/g em mexilhões coletados nos diferentes pontos de cultivo (médias de duplicatas).

\begin{tabular}{cccc}
\hline Microrganismos & Almada & Barra Seca & Costão do Cedro \\
\hline Novembro & $1,9 \times 10^{1}$ & $2,0 \times 10^{1}$ & $3,0 \times 10^{1}$ \\
Dezembro & $2,0 \times 10^{2}$ & $2,0 \times 10^{2}$ & $1,0 \times 10^{2}$ \\
Janeiro & $1,0 \times 10^{2}$ & $1,1 \times 10^{2}$ & $5,5 \times 10^{1}$ \\
Fevereiro & $4,0 \times 10^{1}$ & $1,3 \times 10^{2}$ & $1,0 \times 10^{1}$ \\
Março & $9,0 \times 10^{1}$ & $2,2 \times 10^{2}$ & $4,0 \times 10^{1}$ \\
\hline
\end{tabular}

Apesar do $\mathrm{pH}$ da carne dos mexilhões apresentar-se adequada ao desenvolvimento do C. perfringens, durante todo o estudo, os mexilhões apresentaramse com reduzida carga deste microorganismo; em 53,4\% das amostras não se detectou $C$. perfringens. Apenas uma única amostra atingiu $1,7 \times 10^{2} \mathrm{UFC} / \mathrm{g}(6,7 \%)$, referente ao mexilhão coletada no mês de março, na praia da Barra Seca, conforme mostrado na Tabela 26. Devido ao comportamento anaeróbico do C. perfringens, eles poderão representar um problema de saúde pública, dependendo do processamento do produto e se estes forem embalados a vácuo, cuidados extras devem ser providenciados. 
Tabela 26. Clostridium perfringens NMP/g em mexilhões coletados nos diferentes pontos de cultivo (médias de duplicatas).

\begin{tabular}{cccc}
\hline Microrganismos & Almada & Barra Seca & Costão do Cedro \\
\hline Novembro & $<1,0 \times 10^{1}$ & $1,5 \times 10^{1}$ & $1,5 \times 10^{1}$ \\
Dezembro & $<1,0 \times 10^{1}$ & $<1,0 \times 10^{1}$ & $2,3 \times 10^{1}$ \\
Janeiro & $<1,0 \times 10^{1}$ & $<1,0 \times 10^{1}$ & $1,6 \times 10^{1}$ \\
Fevereiro & $<1,0 \times 10^{1}$ & $<1,0 \times 10^{1}$ & $<1,0 \times 10^{1}$ \\
Março & $7,6 \times 10^{1}$ & $1,7 \times 10^{2}$ & $1,6 \times 10^{1}$ \\
\hline
\end{tabular}

\subsubsection{Enterococcus sp}

A maior contagem de Enterococcus sp encontrada foi referente ao mês de janeiro, quando a amostra da Barra Seca apresentou uma média de 6,8x10 $10^{1} \mathrm{NMP} / \mathrm{g}$ do produto e a menor média foi para o mês de fevereiro, na Almada, com valores de 3,6 NMP/g, conforme mostra a Tabela 27.

Tabela 27. Enterococcus sp NMP/g em mexilhões coletados nos diferentes pontos de cultivo (médias de duplicatas).

\begin{tabular}{cccc}
\hline Microrganismos & Almada & Barra Seca & Costão do Cedro \\
\hline Novembro & 3,6 & 3,6 & 6,3 \\
Dezembro & 9,1 & $2,3 \times 10^{1}$ & $1,5 \times 10^{1}$ \\
Janeiro & $1,3 \times 10^{1}$ & $6,8 \times 10^{1}$ & 9,1 \\
Fevereiro & 3,6 & $2,6 \times 10^{1}$ & 6,3 \\
Março & $1,6 \times 10^{1}$ & $2,6 \times 10^{1}$ & $<3,0$ \\
\hline
\end{tabular}


Cerca de $40 \%$ da contagem de Enterococos, em tecido de mexilhão, foi superior à contagem de coliformes fecais no mesmo material, cerca de 0,6 a 4,2 vezes, concordando parcialmente com os dados citados por Sayler et al. (1976), que afirma em seu estudo que $100 \%$ das contagens de Enterococos foi superior a de coliformes fecais , cerca de 3 a 10 vezes.

Podemos sugerir então maior eficiência de Enterococos como indicadores de contaminação fecal para mexilhões do que os coliformes fecais.

Os mexilhões coletados na praia da Barra Seca foram os que apresentaram maior contagem destes microorganismos, sugerindo a necessidade de uma manipulação mais cuidadosa, ou, uma infra-estrutura mais adequada para as operações de póscaptura.

\subsubsection{Salmonella sp}

Foi constatado resultado positivo para Salmonella sp na coleta do mês de março, na praia da Barra Seca, apesar dos resultados negativos para a pesquisa de Salmonella sp, nas águas de cultivo de todos os pontos de coleta, como mostra a tabela 28. De acordo com as considerações de Germano et al. (1993), a água do mar pode agir como bactericida para as espécies pertencentes à família das enterobactérias e/ou por uma contaminação pós coleta, que pode ser devida à manipulação ou transporte inadequados. 
Tabela 28. Salmonella em 25/g em mexilhões coletados nos diferentes pontos de cultivo (médias de duplicatas).

\begin{tabular}{cccc}
\hline Microrganismos & Almada & Barra Seca & Costão do Cedro \\
\hline Novembro & Ausência & Ausência & Ausência \\
Dezembro & Ausência & Ausência & Ausência \\
Janeiro & Ausência & Ausência & Ausência \\
Fevereiro & Ausência & Ausência & Ausência \\
Março & Ausência & Presença & Ausência \\
\hline
\end{tabular}

Parvey et al. (1974), observaram que a precipitação pluviométrica tende a aumentar o isolamento de salmonelas na água, pois causa a ressuspensão de lodo sedimentado no leito dos cursos d’água, onde há maior concentração de microrganismos. Nesta pesquisa não foi observado resultado positivo para salmonela nas águas de cultivo, mas no mês de março, no qual foi isolada Salmonella de amostras de mexilhões do cultivo da Barra Seca, houve a maior média de pluviosidade comparativamente aos outros meses de coleta, o que pode ter influenciado ressuspensão de células, sendo essas ingeridas e concentradas pelos bivalves através do processo de filtração.

Rodrigues (1998), estudando bivalves advindos de outras regiões de cultivo de Ubatuba, SP, encontraram em amostras de ostras, resultados positivos para Salmonella, procedentes da Enseada de Ubatuba e da Praia do Indaiá. Não sendo detectada presença de Salmonella nas amostras de mexilhões.

O resultado positivo para Salmonella encontrado nesta pesquisa foi identificado como Salmonella entérica, subespécie salamae.

Solic et al. (1999), afirmam que a concentração de Salmonella em moluscos pode ser 50 vezes maior do que em água do mar, fato este que pode ter ocorrido neste trabalho.

Andrews et al. (1975), obtiveram uma relação direta entre níveis de coliformes fecais e Salmonella na carne de ostras Crassostrea virginica, corcondando 
com dados encontrados nesta pesquisa, pois no mês de março, nos mexilhões cultivados na Barra Seca, foi detectada presença de Salmonella; o índice de coliformes fecais foi o mais alto dentre as amostras analisadas, coincidindo também com o índice mais alto de coliformes fecais nas águas de cultivo $\left(5,7 \times 10^{1} \mathrm{NMP} / 100 \mathrm{~mL}\right)$, valores estes, em desacordo com a legislação vigente (Brasil, 1986).

Em conseqüência deste resultado positivo, medidas preventivas devem ser tomadas, pois esta constatação, indica um risco em potencial para os consumidores.

Em alguns países a detecção de Salmonella em bivalves, mesmo quando a água do local estiver dentro dos padrões requeridos, poderá ocasionar a interdiçãoo fechamento deste até que seja providenciada a correção do problema (Martins, 1983b).

A Salmonella está entre as mais importantes causadoras de doenças gastrointestinais, então, o cozimento adequado deste produto, anteriormente ao seu consumo, é altamente recomendado. A Salmonella typhi é a espécie mais comum associada a doenças veiculadas por moluscos, no entanto, segundo autoridades ligadas ao serviço de saúde pública da Europa e da América do Norte, a salmonelose humana associada ao consumo de pescado é rara, se comparada àquelas associadas a outros alimentos, como por exemplo, os produtos avícolas.

\subsubsection{Staphylococcus aureus}

Excetuando-se a coleta do mês de dezembro, quando a amostra de mexilhão da praia

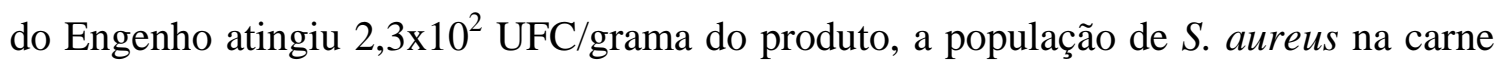
de mexilhão apresentou sempre valores médios menores que 1,0x10² UFC/g para todos os pontos de coleta, durante todo o período de estudo, como mostra a Tabela 29. Todas as amostras apresentaram-se dentro dos limites propostos pelo regulamento técnico sobre padrões microbiológicos em alimentos, Resolução - RDC $n^{0} 12$, de janeiro de 2001, da ordem de $5 \times 10^{2}$ UFC de S. aureus/grama do produto (Brasil, 2001). 
Tabela 29. Sthapylococcus aureus UFC/g em mexilhões coletados nos diferentes pontos de cultivo (médias de duplicatas).

\begin{tabular}{cccc}
\hline Microrganismos & Almada & Barra Seca & Costão do Cedro \\
\hline Novembro & $<1,0 \times 10^{2}$ & $<1,0 \times 10^{2}$ & $1,5 \times 10^{2}$ \\
Dezembro & $2,3 \times 10^{2}$ & $<1,0 \times 10^{2}$ & $<1,0 \times 10^{2}$ \\
Janeiro & $<1,0 \times 10^{2}$ & $<1,0 \times 10^{2}$ & $<1,0 \times 10^{2}$ \\
Fevereiro & $<1,0 \times 10^{2}$ & $<1,0 \times 10^{2}$ & $<1,0 \times 10^{2}$ \\
Março & $<1,0 \times 10^{2}$ & $<1,0 \times 10^{2}$ & $<1,0 \times 10^{2}$ \\
\hline
\end{tabular}

Esta bactéria é encontrada no corpo humano (vias aéreas e cabelos) e transferida ao alimento por pessoas com precários hábitos de higiene, por isso a presença desse microrganismo pode refletir manuseio e/ou condições de armazenamento inadequadas. Portanto, podemos concluir, que os mexilhões coletados em dezembro, na praia do Engenho, podem ter sofrido uma manipulação e armazenamento menos cuidadosos.

Embora a população de $S$. aureus encontrada tenha sido menor do que a prevista pela legislação, o risco potencial de uma toxinfecção causada por este microrganismo existe e dependerá da manipulação do produto e seu posterior armazenamento e processamento, visto que a enterotoxina produzida por este microrganismo é termoresistente.

\subsubsection{Bacillus cereus}

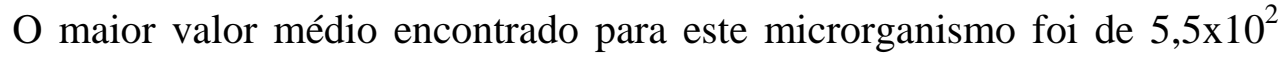
UFC/g, referente ao mês de janeiro, para a praia do Engenho da Almada. O menor foi $<1,0 \times 10^{2} \mathrm{UFC} / \mathrm{g}$, valor que predominou no estudo da carne do mexilhão, representado por $26,7 \%$ das amostras, conforme mostra a Tabela 30. Este microrganismo causa surtos 
quando se apresenta em concentrações acima de $10^{6} \mathrm{UFC} / \mathrm{g}$ de amostra. Nas amostras estudadas neste trabalho, as contagens ficaram em torno de $10^{2}$. Um armazenamento e manipulação inadequados podem propiciar aumento na população microbiana, acarretando sérios riscos.

Tabela 30. Bacillus cereus UFC/g em mexilhões coletados nos diferentes pontos de cultivo (média de duplicatas).

\begin{tabular}{cccc}
\hline Microrganismos & Almada & Barra Seca & Costão do Cedro \\
\hline Novembro & $1,0 \times 10^{2}$ & $<1,0 \times 10^{2}$ & $<1,0 \times 10^{2}$ \\
Dezembro & $5,0 \times 10^{2}$ & $2,0 \times 10^{2}$ & $3,0 \times 10^{2}$ \\
Janeiro & $5,5 \times 10^{2}$ & $2,0 \times 10^{2}$ & $<1,0 \times 10^{2}$ \\
Fevereiro & $<1,0 \times 10^{2}$ & $2,0 \times 10^{2}$ & $1,5 \times 10^{2}$ \\
Março & $5,0 \times 10^{2}$ & $5,0 \times 10^{2}$ & $1,5 \times 10^{2}$ \\
\hline
\end{tabular}

No caso do Bacillus cereus deve-se trabalhar a prevenção deste, pois mesmo havendo posteriormente um controle cuidadoso do binômio tempo $\mathrm{X}$ temperatura no tratamento térmico, métodos rápidos de resfriamento e/ou acidificação, esses microrganismos, como são esporulados apresentam dificuldade para sua inativação e/ou destruição, e podem multiplicar-se, constituindo risco para o consumidor.

\subsubsection{Microrganismos aeróbios mesófilos (Heterotróficos)}

Os valores médios encontrados para estes microrganismos variaram de $1,5 \times 10^{3} \mathrm{UFC} / \mathrm{g}$ no mês de fevereiro, na praia do Engenho da Almada, a 5,1x10 UFC/g no mês de dezembro, no Costão do Cedro, como mostra a Tabela 31. A legislação brasileira apresenta limites para esse grupo de microrganismos, mas a contagem de $10^{5}$, 
é alta, e o produto pode deteriorar-se com grande facilidade. Esses microrganismos estão ligados a manipulação e ao armazenamento em temperaturas inadequadas, e quanto maior o número de indivíduos encontrados, mais rápida será a sua deterioração.

Tabela 31. Heterotróficos UFC/g em mexilhões coletados nos diferentes pontos de cultivo (médias de duplicatas).

\begin{tabular}{cccc}
\hline Microrganismos & Almada & Barra Seca & Costão do Cedro \\
\hline Novembro & $3,9 \times 10^{3}$ & $1,1 \times 10^{4}$ & $1,1 \times 10^{5}$ \\
Dezembro & $3,6 \times 10^{4}$ & $1,8 \times 10^{5}$ & $5,1 \times 10^{5}$ \\
Janeiro & $1,0 \times 10^{4}$ & $4,3 \times 10^{4}$ & $2,3 \times 10^{4}$ \\
Fevereiro & $1,5 \times 10^{3}$ & $1,7 \times 10^{5}$ & $1,5 \times 10^{4}$ \\
Março & $1,4 \times 10^{4}$ & $3,2 \times 10^{4}$ & $3,4 \times 10^{3}$ \\
\hline
\end{tabular}

A contagem desses microrganismos na água, na maioria das amostras esteve baixa, por volta de $10^{1}$, exceto no mês de fevereiro, no Costão do Cedro e em março, na Barra Seca, quando atingiu índices de $10^{2}$, o que atribui às águas de cultivo uma das fontes de contaminação, pois esses microrganismos estão presentes também no habitat do bivalve, concordando com Cook (1991) que afirma que os bivalves, após a sua captura, apresentam em média, $10^{3}-10^{5}$ bactérias/g. Estas contagens normalmente são 1 a 2 unidades logarítmicas maiores que os números encontrados na água onde estes foram colhidos.

\subsubsection{Bolores e leveduras}

O maior desenvolvimento de bolores e leveduras esteve quase sempre relacionado aos produtos provenientes do Costão do Cedro, exetuando-se o mês de 
março de 2003 quando as praias do Engenho e da Barra Seca apresentaram 9,5x10² UFC/ g de amostra, superando o primeiro ponto citado (2x10 $2 \mathrm{UFC} / \mathrm{g})$, conforme mostra a Tabela 32, sendo que a presença de bolores nem sempre é visível, e estes normalmente produzem enzimas que degradam carboidrato, gordura e proteína, causando amolecimento do alimento, além de alterar o flavor e o aroma.

Tabela 32. Bolores e Leveduras UFC/g em mexilhões coletados nos diferentes pontos de cultivo (médias de duplicatas).

\begin{tabular}{cccc}
\hline Microrganismos & Almada & Barra Seca & Costão do Cedro \\
\hline Novembro & $1,0 \times 10^{2}$ & $1,5 \times 10^{2}$ & $4,5 \times 10^{2}$ \\
Dezembro & $1,0 \times 10^{2}$ & $1,0 \times 10^{2}$ & $5,0 \times 10^{2}$ \\
Janeiro & $1,0 \times 10^{2}$ & $1,5 \times 10^{2}$ & $4,5 \times 10^{2}$ \\
Fevereiro & $3,5 \times 10^{2}$ & $2,0 \times 10^{2}$ & $5,0 \times 10^{2}$ \\
Março & $9,5 \times 10^{2}$ & $9,5 \times 10^{2}$ & $2,0 \times 10^{2}$ \\
\hline
\end{tabular}




\section{CONCLUSÕES}

- Todas as amostras de água de cultivo de mexilhões quanto a seus valores de $\mathrm{pH}$, estiveram de acordo com a legislação vigente para águas salinas destinadas a cultivo;

- O Grupo dos coliformes totais obteve boa correlação com outros indicadores como os Enterococos e os Heterotróficos e mostrou-se bom indicador para patógenos como B. cereus;

- Todas as amostras de água tiveram um resultado negativo para Salmonella, o que não ocorreu com os mexilhões, havendo uma amostra positiva no mês de março na praia da Barra Seca, caracterizando um problema de saúde pública;

- O índice pluviométrico interferiu no aumento da contagem microbiana da água de cultivo;

- Tanto os valores de tábua de marés quanto os de insolação diárias, na sua maioria, apresentaram correlação negativa baixa, quando relacionados às contagens microbianas.

- Tanto o S. aureus como B. cereus foram encontrados no mexilhão em contagens baixas, não impedindo, no entanto, que esse alimento possa vir a representar um perigo em potencial, se forem manipulados e/ou armazenados de forma inadequada;

- Todas as amostras de mexilhões apresentaram contagens microbianas superiores aos encontrados na água, fato este que concorda com a afirmação de que os bivalves são citados como amostradores biológicos e bioacumuladores da matéria e/ou substâncias pré existentes na água;

- Observou-se oscilações nos valores das contagens microbianas, no decorrer dos meses de coleta, indicando interferências sazonais na microbiota da água, e 
possivelmente na capacidade de filtração do mexilhão, enfatizando a importância do contínuo monitoramento das águas e físcalização adequada do produto;

- O mexilhão cultivado no município de Ubatuba pode ser considerado um alimento de qualidade, pois as contagens são satisfatórias na grande maioria das coletas, porém consideradas de risco, particularmente no cultivo da Barra Seca;

- É possível recomendar a expansão da atividade de cultivo de mexilhões Perna perna nas regiões analisadas, desde que haja um monitoramento da qualidade da água e dos mexilhões.

\subsection{Recomendações}

- Alertar as autoridades da importância do tratamento de efluentes domésticos (esgotos) antes de serem lançados ao mar, ressaltando-se a importância de medidas preventivas quanto à poluição;

- Faz-se necessário capacitar os produtores quanto à sua importância como produtores e comerciantes no quesito qualidade e sanidade de seus produtos, visando a saúde e bem estar dos consumidores;

- É preciso legalizar a atividade, quanto à certificação do produto (SIF Serviço de Inspeção Federal e Vigilância Sanitária), para que garanta ao consumidor rastreabilidade, qualidade e segurança do alimento comercializado, criando alternativas para o escoamento da produção;

- Dar subsídios à atividade, contribuindo para o seu desenvolvimento equânime socialmente, eficiente economicamente e prudente ecologicamente, garantindo, no futuro uma melhor qualidade de vida para a população local. 


\section{REFERÊNCIAS BIBLIOGRÁFICAS}

AGUDO, E.G.; KRISHNAN, S.A.; TOMMASI, L.R. Evolução da qualidade da água das praias paulistas no quinqüênio 1976-1980. Ciência e Cultura, v.35, n.3, p.283302, 1982.

AHEARN, D.G.; MEYERS, S.P. The role of fungi in the decomposition of hydrocarbons in the marine environment. Ecology, v.53, n.7, p.12-18, 1972.

AMERICAN PUBLIC HEALTH ASSOCIATION. Standard methods for the examination of water and wastewater. 14.ed. Washington: APHA, 1975. 1032p.

AMERICAN PUBLIC HEALTH ASSOCIATION. Standard methods for the examination of water and wastewater. 20.ed. Washington: APHA, 1998. 937p.

AMERICAN PUBLIC HEALTH ASSOCIATION. American water works association \& water environment federation: standard methods for the examination of water and wastewater. 18.ed. Washington: APHA, 1992. 1219p.

ANDERSON, I.C.; RHODES, M.W.; KATOR, H. Seasonal variation in survival of Escherichia coli exposed in situ in membrane diffusion chambers containing filtered and nonfiltered estuarine water. Applied and Environmental Microbiology, v.47, n.9, p.1818877-1883, June 1983. 
ANDREWS, W.H.; DIGGS, C.D.; PRESNELL, M.W. et al. Comparative validity of members of the total coliform and fecal coliform groups for indicating the presence of Salmonella in the Eastern Oyster, Crassostrea virginica. Journal of Milk Food Technology, n.38, p.453-456, 1975.

ASSUMPÇÃO, A. Estudo da viabilidade de criação de cooperativa dos produtores de mexilhões do litoral norte paulista. Piracicaba: ESALQ, Depto. Economia, Administração e Sociologia, 1999. 30p. (Relatório CES, 629)

BARNI, E.J.; SILVA, M.C.; ROSA, S.C.C. et al. Estudo do mercado de mexilhões em três centros consumidores. Porto Alegre: Empresa de Pesquisa Agropecuária e Extensão Rural de Santa Catarina (EPAGRI), 2002. 20p.

BEIRÃO, H.; TEIXEIRA, E.; MEINERT, E.M. et al. Processamento e industrialização de moluscos. In: SEMINÁRIO E WORKSHOP TECNOLOGIA PARA APROVEITAMENTO INTEGRAL DO PESCADO, Campinas, 2000. Palestras. Campinas: ITAL, Centro de Tecnologia de Carnes, 2000. p.38-84.

BENNETT, A.R.; MACPHEE, S.; BETTS, R.; POST, D. Use of pyrrolidonyl peptidase to distinguish Citrobacter from Salmonella. Letters in Applied Microbiology, v.28, n.3, p.175-178, 1999.

BOFFI, A.V. Moluscos brasileiros de interesse médico e econômico. São Paulo: Ed. Hucitec, 1979. 182p.

BONNEFONT, J.L.; MARTIN, Y.P.; GUIENNET, B. Étude experimentale de la decrissance des bacteries fecales en milieu marin quantification, facteurs impliques. Water Research, v.40, n.24, p.263-273, 1990. 
BORGHETTI, J.R.; OSTRENSKY, A. A cadeia produtiva da aqüicultura brasileira. In: VALENTI, W.C.; POLI, C.R.; PEREIRA, J.A.; BORGETTI, J.R. Aqüicultura no Brasil. Brasília: CNPq, 2000. p.107-142.

BRASIL. Ministério da Agricultura e Abastecimento. Secretaria Executiva Departamento de Pesca e Aquicultura (DPA). http://200.252.165.21/dpa/molusco09.htm (13 mar. 2002).

BRASIL. Ministério da Agricultura e Reforma Agrária. Secretaria Nacional de Irrigação. Departamento Nacional de Metereologia. Normais climatológicas (1961-1990). Brasília, 1992. 84p.

BRASIL. Ministério da Agricultura. Regulamento da inspeção industrial e sanitária de produtos de origem animal - RIISPOA. Brasília, 1980. 165p.

BRASIL. Ministério da Saúde. Agência Nacional da Vigilância Sanitária (ANVISA). Resolução RDC $\mathbf{n}^{0} 12$ de 02 de Janeiro de 2001: Regulamento técnico sobre padrões microbiológicos em alimentos. http://www.Anvisa.gov/legis/resol./1201redc.htm. (27 ago. 2001)

BRASIL. Ministério da Agricultura, Pecuária e Abastecimento. Secretaria de Defesa Agropecuária. Departamento de Defesa Animal. Coordenação de Laboratório Animal. Manual de análise microbiológica de produtos de origem animal e água. Brasília, 2002. 196p.

BRASIL. Ministério da Saúde. Portaria $n^{0}$ 451, de 19 de setembro de 1997. Diário Oficial, n.124-E, 02 jul. 1998. Seção 1, p.6. Aprova o regulamento técnico e princípios gerais para o estabelecimento de critérios e padrões microbiológicos para alimentos e seus anexos I, II e III. 
BRASIL. Ministério do Meio Ambiente. Conselho Nacional do Meio Ambiente (CONAMA). Parâmetros de qualidade das águas segundo o seu uso $\begin{array}{lll}\text { preponderante. } & \text { Resolução } & \text { 18/06/1986. }\end{array}$ http://www.mma.gov.br/port/conama/res/res86/res2086.html (20 ago. 2003)

CABELLI, V.J.; DUFOUR, A.P.; McCABE, D.J.; LEVIN, M.A. A marine recreational water quality criterion consistent with indicator concepts and risk analysis. Journal of Water Pollution Control Federation, v.55, n.10, p.1306-1314, 1983.

CABELLI, V.J.; HEFFERNAN, W.P. Accumultion of Escherichia coli by the Northern Quahaug. Applied Microbiology, v.19, n.2, p.239-244, 1970.

CADOGAN, M. O livro dos frutos do mar. São Paulo: Manole, 1992. 120p.

CARDOSO, E.S. Pescadores artesanais: natureza, território, movimento social. São Paulo, 2001. 143p. Tese (Doutorado) - Faculdade de Filosofia, Letras e Ciências Humanas, Universidade de São Paulo.

CAVALCANTE, C.E.M. de H.; SILVA, V.L. da; SALGUEIRO, A.A. Avaliação microbiológica da água do riacho Cavouco, Recife - PE. Higiene Alimentar, v.12, n.57, p.45-49, set./out. 1998.

CETESB amplia rigor para analisar praias. http://www1.folha.uol.com.br (31 dez. 2003)

CHAMBERLIN, C.E.; MITCHELL, R. A decay model for enteric bacteria in natural waters. In: MITCHELL, R. Water pollution microbiology. New York: Wiley, 1978. v.2, p.325-348.

COETZEE, O.J. The viability of Salmonella typhi in sea water. Public Health, v.2, n.63, p.5-11, 1963. 
COLWELL, R.R.; BRADFORD, H.B. Jr.; HOOD, M.A.; LARDSON, A.D. et al. Vibrios in the environment. New York: Willey Interscience, 1984. 634p.

COMPANHIA DE TECNOLOGIA DE SANEAMENTO AMBIENTAL (CETESB). Guia de coleta e preservação de amostras de água. São Paulo, 1988. 149p.

COMPANHIA DE TECNOLOGIA DE SANEAMENTO AMBIENTAL (CETESB). Poluição das águas no estuário e Baia de Santos. São Paulo, 1978. 2v.

COMPANHIA DE TECNOLOGIA DE SANEAMENTO AMBIENTAL (CETESB). Relatório de balneabilidade das praias paulistas 2001. São Paulo, 2002. 209p.

COMPANHIA DE TECNOLOGIA DE SANEAMENTO AMBIENTAL (CETESB). Relatório de balneabilidade das praias paulistas 2002. São Paulo, 2003. 206p.

COMPANHIA ENERGÉTICA DE SÃO PAULO (CESP). Programa de manejo pesqueiro de trabalho 2000-2001. São Paulo: CESP, UHE Engenheiro Sérgio Motta 2000. 74p.

COMPANHIA ENERGÉTICA DE SÃO PAULO (CESP). Programa de monitoramento das características liminológicas e da qualidade da água superficial. São Paulo: CESP, UHE Engenheiro Sérgio Motta, 2000. 13p.

COOK, D.W. Microbiology of bivalves molluscan shellfish. In: WARD, D.R.; HACKNEY, C. Microbiology of marine food products. New York: Van Nostrand Reinhold, 1991. cap.2, p.19-34. 
COOKE, B.W.; PHAFF, H.J.; MILLER, M.W. et al. Yeasts in polluted water and sewage. Mycologia, v.3, n.52, p.210-220, 1960.

DUTKA, B.J. Coliforms are an inadequate index of water quality. Journal of Enviroment Health, v.36, n.1, p.39-46, 1973.

DUTKA, B.J; BELL, J.B. Isolation of Salmonella from moderately polluted waters. Journal of Water Pollution Control, v.45, n.2, p.316-324, 1973.

EMPRESA DE PESQUISA AGROPECUÁRIA E DIFUSÃO DE TECNOLOGIA DE SANTA CATARINA (EPAGRI). Manual do cultivo do mexilhão Perna perna. Porto Alegre, 1994. 140p.

ESPÍNOLA, O.; DIAS, R.R.C. O mexilhão como matéria-prima alimentar. ABIA/SAPRO, n.47, p.10-30, abr. 1980.

EVISON, L.M. Comparative studies on the survival of indicator organisms and pathogens in fresh and seawater. Water Science Technology, n.20, p.309-315, 1988.

FAIR, J.R.; MORRISON, J.R. Recovery of bacterial pathogens and high quality surface water. Water Resources Research, v.10, n.3, p.799-803, 1967.

FAO. El Estado de los recursos pesqueros: tendências de la producción, aproveichamiento y comercio. http://www.fao.org/DOCREP/003/X8002s04.htm (04 jul. 2001) 
FAO. Fisheries Department Statistical Databases and Software. Capture production respect to the previous year. http://www.fao.org/fi/statist/snapshot/01vs00/01vs00.asp (20 abr. 2003)

FELL, J.W.; VAN UDEN, N. Yeast in marine environments. In: OPPENHEIMER, C.H. Symposium on marine microbiology. Springfield: Charles C. Thomas, 1963. p.329-40.

FERNANDES, F.C. Ecologia e biologia do mexilhão Perna perna na Região de Cabo Frio - Brasil. São Paulo, 1981. 145p. Tese (Doutorado) - Instituto Oceanográfico, Universidade de São Paulo.

FERNÁNDEZ-ARMESTO, F. Comida: uma história. São Paulo: Ed. Record, 2004. 362p.

FIM do mangue derruba pesca e renda. Folha de São Paulo. Folha Vale. São Paulo, 17 mar. 2002. p.6.

FRANCO, B.D.G. de M.; LANDGRAF, M. Microbiologia dos alimentos. São Paulo: Atheneu, 1996. 182p.

FREITAS, J.C. O potencial farmacológico das toxinas marinhas: litoral, transformação e beleza. http://www.comciencia.br/reportagens/litoral/lit20.shtml (08 maio 2003)

FUJIOKA, R.S.; HASHIMOTO, H.H.; SIWAK, E.B.; YOUNG, R.H.F. Effect of sunlight on survival of indicator bacteria in seawater. Applied and Environmental Microbiology, v.40, n.3, p.690-696, 1981. 
FURTADO, S.M.B.; DOMINGOS, T.H.; SOARES, A.K. Determinação da composição centesimal e minerais de moluscos (Mytella falcata e Anomalocardia brasiliana) mais consumidos no estado do Rio Grande do Norte Compact disc). In: CONGRESSO BRASILEIRO DE CIÊNCIA E TECNOLOGIA DE ALIMENTOS, 16., Porto Alegre, 1998. Resumos. Porto Alegre: UFRS, 1998.

GALLAGHER, T.P.; SPINO, D.T. The significance of numbers of coliform bacteria as an indicator of enteric pathogens. Water Research, v.2, n.2, p.169-75, 1968.

GALVÃO-BUENO, S. Estudo comparativo da anatomia funcional de Mytella charruana (D’Orbigny, 1846) e Perna perna (Linnaeus, 1758) Bivalvia: Mytilidae. São Paulo, 1977. 96p. Tese (Doutorado) - Instituto de Biociências, Universidade de São Paulo.

GELDREICH, E.E. Fecal coliform concepts in stream pollution. S.1.: Water and Sewage Works, 1967.

GELDREICH, E.E; VAN DONSEL, D.J. Salmonellae in freshwater pollution. /Apresentado ao National Speciality Conference on Desinfection, Amherst, 1970/

GELLI, V.C.; CARNEIRO, M.H. Situação atual da pesca e da maricultura no litoral Norte de São Paulo. São Paulo: Secretaria da Agricultura e Abastecimento, APTA. Instituto de Pesca. Núcleo de Pesquisa e Desenvolvimento do Litoral Norte, 2003. 30p.

GELLI, V.C.; MACHADO, I.C.; PEREIRA, O.M. Diagnóstico da criação de moluscos bivalves no litoral paulista (compact disc). In: SIMPÓSIO BRASILEIRO DE OCEANOGRAFIA, 1., São Paulo, 2002. Anais. São Paulo: Instituto Oceanográfico, 2002. 
GELLI, V.C.; PEREIRA, R.T.L.; GIFFONI, B.B. et al. Caracterização da mitilicultura no litoral norte de São Paulo. In: SEMANA NACIONAL DE OCEANOGRAFIA, 11., Porto Alegre, 1998. Resumos. Porto Alegre: Ed. Universitária, 1998. p.37-40.

GERMANO, P.M.L.; GERMANO, M.I.S.; OLIVEIRA, C.A.F. Aspectos da qualidade do pescado de relevância em saúde pública. Higiene Alimentar, v.12, n.53, p.3037, jan./fev. 1998.

GERMANO, P.M.L.; OLIVEIRA, J.C.F.; GERMANO, M.I.S. O pescado como causa de toxinfecções bacterianas. Higiene Alimentar, v.7, n.28, p.40-45, 1993.

GUILHERME, E.F.M.; SILVA, J.A.M. da; OTTO, S.S. Pseudomona aureginosa, como indicador de contaminação hídrica. Higiene Alimentar, v.14, n.76, p.43-47, set. 2000.

HAGLER, A.N.; HAGLER, L.C.S.M. Indicadores microbiológicos de qualidade sanitária. In: ROITMAM, I.; TRAVASSOS, L.R.; AZEVEDO, J.L. Tratado de microbiologia. São Paulo: Manole, 1988. v.1, cap.3, p.88-96.

HARMON, S.M.; GOEPFERT, J.M.; BENNETT, R.W. Bacillus cereus. In: VANDERZANT, C.; SPLITTSTOESSER, D.F. (Ed.). Compendium of methods for the microbiological examination of foods. 3.ed. Washington: American Public Health Association, 1992. cap.32, p.593-604.

HARTMAN, P.A.; DEIBEL, R.H.; SIEVERDING, L.M. Enterococci. In: VANDERZANT, C.; SPLITTSTOESSER, D.F. (Ed.). Compendium of methods for the microbiological examination of foods. 3.ed. Washington: American Public Health Association, 1992. cap.2. p.523-531. 
HENDRICKS, C.W.; MORRISON, S.M. Multiplication and growth of selected enteric bacteria in clear mountain stream water. Water Research, n.1, p.567-576, 1967.

HENRIQUES, M.B. Avaliação dos bancos naturais do mexilhão Perna perna (L., 1758) na baía de Santos, Estado de São Paulo. Rio Claro, 2001. 74p. Dissertação (Mestrado) - Universidade Estadual Paulista “Júlio de Mesquita Filho”.

HERNANDEZ, C.P. Microbiologia do pescado. Piracicaba: ESALQ, Depto. Agroindústria, Alimentos e Nutrição, 1985. 25p.

HITCHINS, A.D.; FENG, P.; WATKINS, W.D.; RIPPEY, S.R.; CHANDLER, L.A. Escherichia coli and the Coliform bacteria. http://www.cfsan.fda.gov. (14 out. 2001)

HOUSER, L.S. National shellfish sanitation program: manual of operations. Part I. Sanitation of shellfish growing areas. Washington: Dept. Health, Education and Welfare, 1965. 142p.

HUSS, H.H.; REILLY, A.; EMBAREK, P.K.B. Prevention and control of hazards in seafood. Food Control, v.11, p.149-156, 2000.

JAY, J.M. Microbiologia moderna de los alimentos. Zaragoza: Acribia, 1994. 804p.

JAY, J.M. Meats, poultry and seafoods. In: BEAUCHAT, L.R. Food and beverage mycology. 2.ed. New York: Van Nostrand Reinhold, 1987. cap.4, p.155-203.

JOSÉ, V.F. Bivalves e a segurança do consumidor. São Paulo, $1996.182 p$. Dissertação (Mestrado) - Faculdade de Saúde Pública, Universidade de São Paulo. 
KFIR, R.; BURGER, R.; IDEMA, G.K. Detection of Salmonella in shellfish grown in polluted seawater. In: MORRIS, R.W. Health-related water microbiology. New York: Pergamon Press, 1992. p.41-44.

KLAPPENBACH, M.A. Lista preliminary de los mytilidae brasilleños con claves para su determination y notas sobre su distribucion. Anais da Academia Brasileira de Ciências, v.37, p.327-352, 1964. Suplemento.

LABBE, R.G. Clostridium perfringens. In: DOWES, F.P.; ITO, K. (Ed.). Compendium of methods for the microbiological examination of foods. 4.ed. Washington: American Public Health Association, 2001. p.325-330.

LALOO, S.; RAMPERSAD, F.S.; BORDE, A. la; MAHARAJ, K.; SOOKHAI, L. et al. Bacteriological quality of raw oyster in Trinidad and the attitudes, knowledge and perceptions of the public about its consumption. International Journal of Food Microbiology, v.54, n.9, p.99-107, 2000.

LAMPARELLI, C.C. O bivalve Perna perna (Linnaeus, 1758) como amostrador biológico das condições ecológico-sanitárias de águas costeiras. São Paulo, 1987. 124p. Dissertação (Mestrado) - Instituto de Ciências Biológicas, Universidade de São Paulo.

LANCETTE, G.A.; TATINI, S.R. Staphylococcus aureus. In: DOWES, F.P.; ITO, K. (Ed.). Compendium of methods for the microbiological examination of foods. 4.ed. Washington: American Public Health Association, 2001. p.387-403.

LEGNANI, P.; LEONI, E.; LEV, D. et al. Distribution of indicador bacteria and bacteriophages in shellfish and shellfish-growing waters. Journal of Applied Microbiology, v.3, n.85, p.790-798, 1998. 
LIRA, A. de A.; BARROS, G.C.DE.; LIMA, M.C.G.DE.; MOTA, R.A. Aspectos sanitários do ambiente aquático onde são capturados moluscos bivalves para consumo no Grande Recife, PE. Higiene Alimentar, v.11, n.77, p.53-57, out. 2000.

LIZÁRRAGA-PARTIDA, M.L.; CÁRDENAS, G.V. Influence of water circulation on marine and faecal bacteria in a mussel-growing area. Marine Pollution Bulletin, v.32, n.2, p.196-201, 1996.

MAHASNEH, A.N.; AL-SAYED, H.A. Seasonal incidence of some heterotrophic aerobic bacteria in Bahrain pelagic and nearshore waters and oysters. International Journal of Environmental Studies, v.51, p.301-312, 1997.

MARQUES, H.L.A. Criação comercial de mexilhões. São Paulo: Nobel, 1998. 111p.

MARQUES, H.L.A; PEREIRA, R.L. Levantamento e dimensionamento preliminares das áreas mais favoráveis para a prática da mitilicultura no Litoral do município de Ubatuba, estado de São Paulo ( $\left.23^{0} 25^{\prime} \mathrm{S}, 045^{0} 04^{\prime} \mathrm{W}\right)$. Ubatuba: Instituto de Pesca, 1989. 10p. (Boletim Técnico do Instituto de Pesca, 13)

MARTINEZ-MANZANARES, E. Comparison and evaluation of different microbiological quality criteria for shellfish and shellfish-growing waters. In: MORRIS, R.W. Health-related water microbiology. New York: Pergamon Press, 1992. p.31-34.

MARTINS, M.T. Caracterização microbiológica das praias da Baixada Santista. In: SEMINÁRIO SOBRE UMA SÍNTESE DO CONHECIMENTO SOBRE A BAIXA DA SANTISTA, Santos, 1983. Resumos. São Paulo: Companhia de Tecnologia de Saneamento Ambiental, 1983a. v.1, p.81. 
MARTINS, M.T. Isolamento de Vibrio e Salmonella em moluscos bivalves e sua relação com a qualidade da água. Higiene Alimentar, v.2, n.3, p.55, 1983b

MEYERS, S.P.; AHEARN, D.G.; GUNKELL, W.; ROTH, F.J.J. Yeasts from the North Sea. Marina Biology, n.1, p.188-23, 1967.

MOLUSCOS: cadeia produtiva: histórico do cultivo de moluscos bivalves no Brasil. http://www.setorpesqueiro.com.br (12 mar. 2002)

MORTON, R.D. Aerobic plate count. In: DOWNES, F.P.; ITO, K. (Ed.). Compendium of methods for the microbiological examination of foods. 4.ed. Washington: American Public Health Association, 2001. p.63-67.

NATIONAL ADVISORY COMMITTEE ON MICROBIOLOGICAL CRITERIA FOR FOODS. Microbiological criteria for raw molluscan shellfish. Journal of Food Protection, v.55, n.6, p.463-480, June 1992.

NÓBREGA, N.D. da. Indicadores de poluição no estuário do rio Potengi e em água de esgoto em Natal/ RN. São Paulo, 1982. 121p. Dissertação (Mestrado) - Instituto de Ciências Biológicas, Universidade de São Paulo.

NORT, E. Importância do controle físico na qualidade do pescado. /Apresentado ao Seminário Sobre Controle de Qualidade na Indústria de Pescado, Santos, 1988/

OETTERER, M. Agroindústrias beneficiadoras de pescado cultivado-unidades modulares e polivalentes para implantação, com enfoque nos pontos críticos higiênicos e nutricionais. Piracicaba, 1999. 199p. Tese (Livre-docência) - Escola Superior de Agricultura Luiz de Queiroz, Universidade de São Paulo. 
OSTRENSKY, A.; BORGHETTI, J.R.; PEDINI, M. Situação atual da aqüicultura brasileira e mundial. In: VALENTI, W.C.; POLI, C.R.; PEREIRA, J.A.; BORGETTI, J.R. Aqüicultura no Brasil. Brasília: CNPq, 2000. p.355-381.

PÁDUA, H.B. Informações sobre coliformes totais/fecais e alguns outros organismos indicadores em sistemas aquáticos. http://www.pescar.com.br/helcias (10 maio 2003)

PAOLETTI, A. Facteurs biologiques d'autoeduration dês eaux de mer; points clairs et points obscurs d'une question discutés. Revista Internacional de Oceanografia Médica, v.18, n.19, p.33-68, 1978.

PARVERY, F.; CHAMBREUIL, G.; BECAUD, J.P. et al. Estude écologique des Salmonella dans une rivière em zone urbaine: la Maine à Angers. Revisté Épidémie, n.22, p.125-136, 1974.

PAULA, C.R. Contribuição ao estudo das leveduras em praias da baixada santista. São Paulo, 1978. 86p. Dissertação (Mestrado) - Instituto de Ciência Biológicas, Universidade de São Paulo.

PELCZAR, M.J. Jr.; CHAN, E.C.S.; KRIEG, N.R. Microbiologia, conceitos e aplicações. São Paulo: Makron, 1996. cap.29, p.337-369: Microbiologia das águas naturais, potáveis e dos esgotos.

PEREIRA, O.M.; GELli, V.C.; HENRIQUES, M.B. et al. Programa de desenvolvimento da criação ordenada de moluscos bivalves no Estado de São Paulo. http://www.pesca.sp.gov.br/RelTec2.htm (21 mar. 2003)

PIMENTEL-GOMES, F. Curso de estatística experimental. 13.ed. São Paulo: Nobel, 1990. 468p. 
PINHEIRO JUNIOR, A.A. Colimetria de águas marinhas e mexilhões (Perna perna LINNAEUS, 1758) em áreas de cultivo e extrativismo no município de Niterói, RJ. Rio de Janeiro, 2000. 70p. Dissertação (Mestrado) - Faculdade de Medicina Veterinária, Universidade Federal Fluminense.

PLUSQUELLEC, A. Enumeration of bacterial contamination of bivalves: monitoring the marine bacterial pollution. Marine Pollution Bulletim, v.14, n.7, p.160-263, 1983.

PORRELLI, P.; GALVÃO, J.A; FURLAN, E.F. et al. Interferência das características biométricas na composição centesimal de mexilhões Perna perna (L.) (compact disc). In: SIMPÓSIO INTERNACIONAL DE INICIAÇÃO CIENTÍFICA DA UNIVERSIDADE DE SÃO PAULO, 11., Piracicaba, 2003. Resumos. São Paulo: USP, 2003.

PREGNOLATTO, W.; PREGNOLATTO, N.P. Normas analíticas do Instituto Adolfo Lutz. São Paulo: Instituto Adolfo Lutz, 1985. v.1, 533p.

PROENÇA, C.E.M.; AVELAR, J.C.; NETO, F.M.O. Plataforma do agronegócio da malacocultura. Brasília: CNPq. MAPA, DPA, 2001. 76p.

PROGRAMA MEXICANO DE SANIDADE DE MOLUSCOS BIVALVOS. Manual de operacion: I. Control sanitário de áreas de produccion de moluscos bivalvos. México: Talleres Gráficos de la Nacion, 1989. 81p.

QUAYLE, D.B.; NEWKIRK, G.F. Farming bivalve molluscs: methods for study and development. In: SANDIFRE, P.A. Advances in world aquaculture. Toronto: The World Aquaculture Society, 1989. v.1, p 37-42. 
RELATÓRIO anual aponta melhores condições de balneabilidade no litoral paulista. http://www.setorpesqueiro.com.br/noticias/noticias2.asp/id=8285 (05 ago. 2003)

RHODEHAMEL, E.J.; HARMON, S.M. Bacillus cereus. In: GAITHERSBURG, M.D. (Ed.). Bacteriological analytical manual. 8.ed. Washington: AOAC, 1995, p.14.0114.08 .

RHODEHAMEL, E.J.; HARMON, S.M. Clostridium perfringens. http://www.cfsan.fda.gov (27 Oct. 2001)

RINALDI, F.D.; FURLAN, E.F.; GALVÃO, J.A. et al. Produção, comercialização e perspectivas de expansão da atividade de cultivo de mexilhão Perna perna (L.) na região de Ubatuba/SP (compact disc). In: SIMPÓSIO INTERNACIONAL DE INICIAÇÃO CIENTÍFICA DA UNIVERSIDADE DE SÃO PAULO, 11., Piracicaba, 2003. Resumos. São Paulo: USP, 2003.

RODRIGUES, P.F. Caracterização sanitária de áreas de criação de moluscos bivalvos do litoral Norte do Estado de São Paulo. São Paulo, 1998. 66p. Dissertação (Mestrado) - Instituto de Ciências Biológicas, Universidade de São Paulo.

SALATI FILHO, E. Condicionantes do desenvolvimento sustentável do Litoral Norte Paulista: o exemplo da bacia do córrego da Lagoinha - Ubatuba, SP. Rio Claro, 2001. 148p. Tese (Doutorado) - Universidade Estadual Paulista "Júlio de Mesquita Filho".

SANTOS, E. Zoologia brasilica: moluscos do Brasil. Belo Horizonte: Itatiaia, 1982. $141 \mathrm{p}$.

SARIKAYA, H.Z.; SAATCI, A.M. Bacterial die-away rates in Red Sea waters. Water Science Technology, n.32, p.45-52, 1995. 
SATO, M.I.Z.; MONTEIRO, C.K.; STOPPE, N.C. et al. Shellfish and marine microbiological quality. Environmental Toxicology and Water Quality, v.7, p.95105, 1992.

SAYLER, G.S.; NELSON, J.D; JUSTICE, A.; COLWELL, R.R. Incidence of Salmonella spp., Clostridium botulinum, and Vibrio parahaemolyticus in an Estuary. Applied Environment Microbiology, v.31, n.5, p.723-730, 1976.

SERVIÇO DE APOIO ÀS MICRO E PEQUENAS EMPRESAS DE SÃO PAULO (SEBRAE); UNIVERSIDADE FEDERAL DE SÃO CARLOS. Grupo de Estudos e Pesquisas Agroindustriais. Diagnóstico e proposição de ações de melhoria da eficiência e da competitividade das cadeias produtivas da carcinicultura marinha e moluscos bivalves no Estado de São Paulo (compact disc). São Carlos, 2002.

SIDALL, S.E. A clarificarion of the genus Perna (Mytilidae). Bullettin of Marine Science, v.4, n.30, p.858-870, 1980.

SILVA, N. da; CANTUSIO NETO, R.; JUNQUEIRA, V.C.A. et al. Manual de métodos de análise microbiológica da água. Campinas: ITAL, 2000. 99p.

SOLIC, M.; KRSTULOVIC, N.; JOZIC, S.; CURAC, D. The rate of concentration of faecal coliforms in shellfish under different environmental conditions. Enviroment International, v.25, n.8, p.991-1000, 1999.

SOUZA, R.C.C.L. de. Bivalves marinhos introduzidos no Brasil. ENCONTRO BRASILEIRO DE MALACOLOGIA, 18., Rio de Janeiro, 2003. Resumos. Rio de Janeiro: UERJ, 2003. 
TAVARES, M.; SABRIA, A.; BACETTI, L.B. et al. Métodos sensoriais, físicos e químicos para análise de pescado. /Apresentado ao Seminário Sobre Controle de Qualidade na Indústria de Pescado, Santos, 1988/

TOMMASI, L.R. A degradação do meio ambiente. 4.ed. São Paulo: USP, 1979. 169p.

TURICK, C.E.; SEXTONE, A.J., BIOSSONNETTE, G.K. Freshwater mussels as monitors of bacteriological water quality. Water, Air, Soil Pollution, n.40, p.449460, 1988.

WOOD, F. The living ocean. Washington: Croom Helm, 1975. 146p.

WORLD HEALTH ORGANIZATION (WHO). Food safety issue associated with products from aquaculture. Roma: FAO, 1999. (Report of a Joint FAO/NACA/FAO Study Group. WHO Technical Report Series, 883) 